\title{
RURAL MISSOURI HIGH SCHOOL PRINCIPALS' PERCEPTIONS OF HIGHLY EFFECTIVE TEACHERS: DOES IT ALIGN WITH NATIONAL RESEARCH?
}

A Dissertation in Practice
presented to
the Faculty of the Graduate School
at the University of Missouri-Columbia
In Partial Fulfillment
of the Requirements for the Degree
Doctor of Education
by beIA SANKEY
Dr. Juanita Simmons, Dissertation Supervisor
DECEMBER 2017




\section{PRINCIPALS' PERCEPTIONS}

The undersigned, appointed by the dean of the Graduate School, have examined the dissertation entitled

\section{RURAL MISSOURI HIGH SCHOOL PRINCIPALS' PERCEPTIONS OF HIGHLY} EFFECTIVE TEACHERS: DOES IT ALIGN WITH NATIONAL RESEARCH?

presented by Marcia Sankey, a candidate for the degree of doctor of Doctor of Education, and hereby certify that, in their opinion, it is worthy of acceptance.

\begin{tabular}{c}
\hline Dr. Juanita Simmons, Chair \\
\hline Dr. Emily Crawford \\
\hline Dr. Carol Maher \\
\hline
\end{tabular}

Dr. Todd Whitaker 


\section{PRINCIPALS’ PERCEPTIONS}

\section{Dedication}

I want to thank all of my friends and family for their immense support over the last four years and their tolerance of my absenteeism at some important functions. To my children, I want you to know you inspire me to do more, to be more, to pursue more and to set that example for you. To my grandchildren, who arrived after I began this journey, I promise to take more time to be grandma in the months and years to come. I always want to inspire you to be learners and never let your present dictate the future.

I especially want to thank my soul mate, Bruce, who encouraged me to start this journey and has supported me in every way throughout the entire process. Thank you for all of the shopping and cooking and cheerleading along the way. You are my best friend. Thank you. 


\section{PRINCIPALS’ PERCEPTIONS}

\section{Acknowledgments}

I would like to thank Dr. Juanita Simmons for your advice and guidance, as well as your encouragement and support to think outside of the box throughout this entire process. I would also like to thank my committee members, Dr. Emily Crawford, Dr. Carol Maher, and Dr. Todd Whitaker for your feedback and support in completing this work.

I would like to thank all of the professors involved in the MU ELPA cohort program for your encouragement and support for all of us working professionals. Your timely, constructive feedback helped me grow as a student and as an educator.

Finally, I would like to thank all of my Columbia Cohort Nine members for the support and group learning that has occurred over the last four years. I appreciate all of you and your willingness to give feedback and support at all times. 
PRINCIPALS' PERCEPTIONS

\section{Table of Contents}

Acknowledgments

Section One: Introduction to the Dissertation 1

$\begin{array}{lr}\text { Introduction } & 2\end{array}$

$\begin{array}{ll}\text { Background } & 4\end{array}$

$\begin{array}{ll}\text { Statement of the Problem } & 10\end{array}$

$\begin{array}{ll}\text { Problem of Practice } & 10\end{array}$

$\begin{array}{ll}\text { Possible Barriers to Hiring Effective Teachers } & 11\end{array}$

$\begin{array}{ll}\text { Existing Gaps in the Literature } & 12\end{array}$

$\begin{array}{ll}\text { Purpose of the Study } & 13\end{array}$

$\begin{array}{ll}\text { Research Questions } & 14\end{array}$

$\begin{array}{ll}\text { Conceptual/Theoretical Framework } & 15\end{array}$

Design of the Study 16

$\begin{array}{ll}\text { Setting } & 17\end{array}$

$\begin{array}{ll}\text { Participants } & 18\end{array}$

Table \#1 - Participants in the Study 20

Data Collection Tools $\quad 21$

$\begin{array}{ll}\text { Data Analysis } & 22\end{array}$

Limitations, Assumptions, and Design Controls 23

$\begin{array}{lr}\text { Definitions of Key Terms } & 24\end{array}$

$\begin{array}{ll}\text { Significance of the Study } & 26\end{array}$

$\begin{array}{ll}\text { Scholarship } & 26\end{array}$

$\begin{array}{ll}\text { Practice } & 27\end{array}$ 


\section{PRINCIPALS' PERCEPTIONS}

$\begin{array}{ll}\text { Summary } & 28\end{array}$

Section Two: Practitioner Setting for the Study 29

$\begin{array}{ll}\text { Introduction } & 30\end{array}$

History of the Organization $\quad 30$

$\begin{array}{ll}\text { Organizational Analysis } & 31\end{array}$

$\begin{array}{ll}\text { Structural Frame } & 31\end{array}$

Human Resource Frame $\quad 32$

$\begin{array}{ll}\text { Leadership Analysis } & 33\end{array}$

Implications for Research in Practitioner Setting 42

$\begin{array}{ll}\text { Summary } & 43\end{array}$

Section Three: Scholarly Review for the Study 44

$\begin{array}{ll}\text { Introduction } & 45\end{array}$

Reform Efforts, Teacher Quality, and Learning Gap 45

Teacher Evaluations and Highly Effective Teachers 48

$\begin{array}{ll}\text { Principals' Perceptions } & 52\end{array}$

$\begin{array}{lr}\text { Summary } & 55\end{array}$

Section Four: Contribution to Practice $\quad 57$

Plan for Dissemination of Practitioner Contribution 58

$\begin{array}{lr}\text { White Paper Introduction } & 59\end{array}$

$\begin{array}{lr}\text { Problem of Practice } & 59\end{array}$

$\begin{array}{lr}\text { Findings } & 60\end{array}$

Highly Effective Teacher as Observed in Classroom 61

Highly Effective Teacher as Identified in an Interview 67 
PRINCIPALS' PERCEPTIONS

Table \#2 - Characteristics of Teacher Applicant

Red Flags of Ineffectiveness

Table \#3 - Red Flags

Discussion

Recommendations

Conclusions

References

Section Five: Contribution to Scholarship

Target Journal and Rationale

Abstract

Introduction

Review of the Literature

Reform Efforts, Teacher Quality, and Learning Gap

Teacher Evaluations and Highly Effective Teachers

Principals' Perceptions

Summary

93

Current Study

94

Research Questions

95

Conceptual/Theoretical Framework

96

Design of the Study

97

Setting

98

Participants

99

Table \#1 - Participants in the Study

101 


\section{PRINCIPALS’ PERCEPTIONS}

$\begin{array}{ll}\text { Data Collections Tools } & 102\end{array}$

$\begin{array}{ll}\text { Data Analysis } & 103\end{array}$

Limitations, Assumptions, and Design Controls 104

$\begin{array}{ll}\text { Results and Discussion } & 105\end{array}$

$\begin{array}{ll}\text { Findings } & 105\end{array}$

Highly Effective Teachers as Observed in a Classroom 106

Highly Effective Teachers as Identified in an Interview 112

Table \#2 - Characteristics of Teacher Applicant 116

$\begin{array}{ll}\text { Red Flags of Ineffectiveness } & 117\end{array}$

Table \#3 - Red Flags $\quad 118$

$\begin{array}{lr}\text { Discussion } & 119\end{array}$

$\begin{array}{ll}\text { Recommendations } & 121\end{array}$

$\begin{array}{lr}\text { Conclusion } & 123\end{array}$

$\begin{array}{lr}\text { Future Research } & 123\end{array}$

$\begin{array}{ll}\text { References } & 125\end{array}$

Section Six: Scholarly Practitioner Reflection 132

$\begin{array}{ll}\text { Scholarly Practitioner Reflection } & 133\end{array}$

Dissertation Influence on Practice as an Educational Leader 133

Dissertation Process Influence on Scholarly Focus 134

$\begin{array}{ll}\text { References } & 135\end{array}$

$\begin{array}{ll}\text { Appendix A } & 144\end{array}$

$\begin{array}{ll}\text { Appendix B } & 146\end{array}$

$\begin{array}{ll}\text { Vita } & 147\end{array}$ 


\section{PRINCIPALS' PERCEPTIONS}

SECTION ONE:

INTRODUCTION TO DISSERTATION 


\section{PRINCIPALS’ PERCEPTIONS}

\section{Introduction}

An excellent, highly effective teacher is the single most powerful influence on student achievement (Hattie, 2003). How can rural Missouri school districts and high school principals ensure all teachers are highly effective? All students deserve access to highly effective teachers and an opportunity at an excellent education. With the increased national focus on college and career readiness skills and abilities of students graduating from American high schools, ensuring all teachers in all classrooms are highly effective is one of the most important responsibilities of principals in schools today (Stronge, Richard, \& Catano, 2008; Wright, Horn, \& Sanders, 1997). As the educational leader of the school, the ability of the principal to identify a highly effective teacher is a critical link in placing highly effective teachers in every classroom (Stronge et al., 2008). Research identifies strong district cohesiveness, which includes strong principal leadership as well as highly effective teachers working together, as a key factor in closing the learning gap (Leithwood, 2010). What do principals perceive as the characteristics of a highly effective teacher? As they assess the skills of current teachers and attempt to fill open positions, what are they looking for in an effective teacher? Do their perceptions accurately reflect the characteristics of an effective teacher as supported by research or is there a conflict between the research and their perceptions?

In general, according to the research, a highly effective teacher is one who possesses strong diverse pedagogical skills to manage a classroom, strong subject content knowledge, as well as the pedagogical content knowledge to teach the subject in a way that reaches all students (Hattie, 2003; Leithwood, 2010; Shulman, 1986). In the words of Shulman (1986), "an effective teacher is not only a master of procedure but is also 


\section{PRINCIPALS' PERCEPTIONS}

highly skilled in content and is able to explain the rationale for why something is done" (p. 10). Shulman (1986) proposed his ideas in a time when he felt reforms in education seemed to focus on the pedagogical skills of teachers, while ignoring their strength in subject content knowledge. Shulman felt that reform leaders had taken the results of research and put too much emphasis on the pedagogical knowledge of teachers (1986). A 1990 study by Grossman also identified teachers with both strong subject content knowledge and pedagogical training as more successful in the classroom than those without the pedagogical skills. More recent research continues to support this idea and includes the teacher's ability to help students make prior connections with learning as an additional characteristic of effective teachers (Darling-Hammond, 2000; DarlingHammond, 2012; Darling-Hammond, Amrein-Beardsley, Haertel, \& Rothstein, 2012; Darling-Hammond, Holtzman, Galtin, \& Vazquez Heilig, 2005; Hattie, 2003). It is also important to note that student/teacher relationships are key factor in student achievement, however, in this study it will be considered as part of the pedagogical skill of the teacher and not studied separately. For this study, the definition of a highly effective teacher is someone with strong pedagogical skills and subject content knowledge, as well as the pedagogical content knowledge to reach and teach all students (Holland, 2007; Leithwood, 2010). Therefore, it comes to no surprise that research suggests that strong principal leadership is a key part of ensuring all students have access to effective teachers. In rural communities, there can be more tension between the professional practices of the school personnel and the expectations and values of the community (Budge, 2006). As leaders, rural Missouri high school principals face the challenge of 


\section{PRINCIPALS’ PERCEPTIONS}

leading in close-knit communities and dealing with rurality ${ }^{1}$ of the community members and their expectations (Budge, 2006). With these challenges in mind, do the perceptions of rural Missouri high school principals agree with the research as they attempt to identify a highly effective teacher for every classroom?

The purpose of this study is to clarify and understand what rural Missouri high school principals perceive as the characteristics of highly effective teachers and whether or not their perceptions align with that of national standards and expectations for securing effective teachers. Research shows that a highly effective teacher is the most important factor in improving education for all students and closing the learning gap (Hattie, 2003). As the link between identifying highly effective teachers and placement of these teachers in classrooms, it is important to understand the principals' perceptions of highly effective teachers. In many cases perceptions are the foundations of beliefs and an incorrect perception could support an incorrect belief that a teacher is highly effective when in reality they are not.

\section{Background}

For decades, the federal government has been working to make improvements in the educational system to provide the opportunity of an excellent education to all American students. Early reform began with the 1954 Brown vs. Board of Education Supreme Court decision to end segregation in schools in an attempt to end the inequalities found in the condition and quality of schools (U.S. Department of Education, 2004). Ending segregation in our nation's schools, however, did not happen immediately and was not enough to level the playing field for all students to have equal access to a

\footnotetext{
${ }^{1}$ Rurality $=$ sense of place with strong feelings of attachment by inhabitants (Budge, 2006).
} 


\section{PRINCIPALS' PERCEPTIONS}

quality education and highly effective teachers. There continued to be an inequality in funding, access to necessary resources, as well as effective teachers for students attending schools in less affluent school districts. In 1965 Congress passed the Elementary and Secondary Education Act (ESEA) to provide better funding to disadvantaged school districts across the country (ESEA, 1965). The goal was to provide much needed access to books and teaching tools otherwise lacking in many poor school districts. Several special education reforms followed in the 1970s, which opened the door even further to opportunities in public schools for all children, especially those with barriers to learning (U.S. Department of Education, 2004). Even with these changes in place, however, progress was slow and access to highly effective teachers and a quality education was still limited for many American students.

In 1971, the National Center for Educational Statistics began to collect data on the academic achievement levels of all American students to monitor the progress of the reforms made up to this point. This data identified an obvious learning gap between middle and upper class Caucasian students, African-American, and Hispanic students, as well as students from lower socio-economic backgrounds (National Center for Educational Statistics, 2013). Using this information, reformers attempted to close this gap through improvements in teacher training programs and the introduction of standardized testing in many states. Due to these changes, statistics show some progress was made at this time. In 1983, the government released A Nation at Risk Report, which revealed that though more students from all groups were graduating from high school, a significant learning gap continued to exist between middle and upper class Caucasian students and almost all other racial, ethnic, and socio-economic groups. According to 


\section{PRINCIPALS' PERCEPTIONS}

this report, Hispanic and African-American students, as well as students from lower socio-economic situations, were continuing to achieve at much lower levels in all academic areas (A Nation at Risk, 1983). The results of this report emphasized the need for continued improvement in teacher education programs as well as better methods of improving the skills of teachers already in the classrooms. The emphasis of the reforms stemming from this report, however, seemed to put more focus on overall excellence rather than closing the learning gap.

In response, researchers and educational leaders increased a focus on improving teachers through better teacher evaluation systems. At this time, there were many different approaches to teacher evaluation in use with no common focus and measuring different aspects of teaching and the teacher (Darling-Hammond, Wise, and Pease, 1983; Lewis, 1982). The design of some evaluation systems attempted to measure the quality of the teacher while others tried to measure the quality of the teaching and other systems focused on student outcomes to assess teacher effectiveness (Darling-Hammond et al., 1983). As a result, some researchers attempted to create a more useful streamlined system, which included teacher input as well as peer review as part of the process (Gitlin \& Smyth, 1989; McLaughlin \& Pfeifer, 1988). Educational leaders and policy makers began to publish systematic guidelines for principals to evaluate teachers in a way that would provide feedback and opportunities to improve classroom activities and student learning. Guidelines developed from this research formed the foundation of the performance based teacher evaluation system, otherwise known as PBTE, used in school districts for several decades and seemed to have a heavy focus on the pedagogical skills and knowledge of the teacher. Whereas evaluation systems might have assisted in 


\section{PRINCIPALS’ PERCEPTIONS}

assessing effectiveness of hired teachers, the question remains - Do principals in all districts consider these measures when hiring teachers?

Shulman (1986), however, felt policy-makers had taken the research on teacher evaluation systems and focused reform on the pedagogical skills of the teacher as the key to quality evaluation and had overlooked or minimized the content knowledge of the teachers. His research indicated highly effective teachers needed strong pedagogical knowledge (PK), along with subject content knowledge (SCK), as well as pedagogical content knowledge (PCK), or the knowledge of how to teach specific content (Shulman, 1986). Shulman argued teachers must be able manage a classroom (PK), know well the correct content to teach (SCK), and have the ability to teach the subject content in a variety of ways to reach all students (PCK). The blending of all these skills together make a highly effective teacher in the classroom (Shulman, 1986). Grossman (1990) conducted a study, which supports the PCK concept described by Shulman (1986). In a study of young teachers, Grossman (1990) identified those who possessed both strong pedagogical training and strong content knowledge as more prepared for the classroom setting than those possessing only strong subject content knowledge.

Other researchers also sought to improve the quality of teachers through better evaluation methods and called for not only standardized performance expectations but also teacher specific information such as a portfolio as part of a collaborative effort between teacher and principal to improve classroom teaching (Millman \& DarlingHammond, 1990). At this time, we also see an increased research interest in the transformational approach to leadership (Northouse, 2013). In the field of education, this approach puts more emphasis on the principal as a charismatic, visionary leader who can 


\section{PRINCIPALS’ PERCEPTIONS}

empower teachers through connections and relationships (Northouse, 2013). Through all of these efforts, classroom instruction did improve and the learning gap began to decrease; however, even though many states had successfully decreased the size of the learning gap by the late 1990's, none had been able to close it completely (National Center for Educational Statistics, 2013). The continued learning gap triggered a new round of legislation with a new focus on school district accountability for student learning. This legislation became known as No Child Left Behind (NCLB, 2001) and was signed into law in 2002. NCLB increased the level of federal involvement in public education and increased the pressure on states to raise the test scores of all students, turn around failing schools, and close the learning gap (NCLB, 2001). Like all public schools in the nation, rural Missouri high schools also had to meet this expectation, which put a lot of pressure on all school personnel to raise test scores, improve student performance, and turn around failing schools (NCLB, 2001). In the case of failing schools, principals were threatened with the loss of their position in the school if they were unable to turn the school around and improve outcomes, which put even more pressure on teachers in these schools (NCLB, 2001).

Some of the responsibility for accountability has been returned to the control of the states through the Every Student Succeeds Act (ESSA, 2015), however, there is still heavy emphasis on systems for accountability for student learning as an indicator of effectiveness. Accountability includes collecting and analyzing data as one of the most common methods to determine improvement for individual schools and school districts (NCLB, 2001; ESSA, 2015). Types of data collected at the state and local level include demographics, economic information, as well as the results of high-stakes standardized 


\section{PRINCIPALS’ PERCEPTIONS}

assessments. State education departments analyze all these data and disseminate this information to the school districts, where it is expected to be used to determine the yearto-year growth of all students and identify areas in need of improvement in the district. One of the most important pieces of data that districts regard as evidence of improvement in closing the learning gap is the testing data. Results of high stakes tests can identify areas of strength or weakness for individual students as well as identify gaps in learning between various demographic groups of students. Increasingly, using these types of data, the school districts attempt to focus on the skill of the individual teacher in the classroom and his/her ability to reach and teach every single student. The increased focus on accountability increases the expectation that all teachers in all classrooms are highly effective (Looney, 2011).

The responsibility of the principal to ensure every classroom has a highly effective teacher has long been one of the most challenging tasks for school districts to do in a timely, worthwhile manner (Cooper, Ehrensal, \& Bromme, 2005; Looney, 2011). The role of the principal has expanded over the last several years from managing supervisor of the school to a role, which now also includes being an instructional leader who works to improve teacher effectiveness in the classroom (Cooper et al., 2005). As the instructional leader, it is vital the principal has the skill to identify an effective teacher while assessing the skills of current teachers as well as during the hiring process. For rural Missouri high school principals this challenge may be even greater when the candidate pool is small or they have no applicants for an open position. When principals are attempting to identify highly effective teachers, however, are they looking for all of 


\section{PRINCIPALS' PERCEPTIONS}

the characteristics of PK, PCK, and SCK as identified by national research or do they prioritize relationships, cultural fit, or candidate potential?

\section{Statement of the Problem}

\section{Problem of Practice}

Data and research shows that a highly effective teacher in the classroom is one of the best tools for closing the learning gap (Donaldson, 2013; Hattie, 2003; Johnson, 1999; Leithwood, 2010). The most highly effective teachers -

possess knowledge that is more integrated, in that they combine new subject matter content knowledge with prior knowledge; can relate current lesson content to other subjects in the curriculum; and make lessons uniquely their own, by changing, combining, and adding to them according to their students' needs and their own goals. (Hattie, 2003, pp. 6-7)

The problem, however, is whether rural Missouri high school principals perceive and identify the same characteristics of highly effective teachers, as is indicated by what research shows as the most important characteristics. Are principals truly able to identify highly effective teachers as they assess current teachers and interview prospective teachers? National research identifies a highly effective teacher as someone who has strong subject content knowledge, pedagogical skills to manage a classroom, as well as the pedagogical content knowledge to teach the subject in a variety of ways to all students (Darling-Hammond, 2000; Darling-Hammond et al., 2012; Hattie, 2003). A highly effective teacher is someone who can reach and teach all students, which includes 


\section{PRINCIPALS’ PERCEPTIONS}

the ability to build strong relationships with students, and is capable of closing the learning gap (Hattie, 2003; Holland, 2007; Leithwood, 2010).

\section{Possible Barriers to Hiring Effective Teachers}

With all of these expectations in mind it is important to understand that identifying, hiring, and retaining the most highly effective teachers are extremely important and at the same time very difficult tasks for school district principals to carry out (Donaldson, 2013). Coinciding with this challenge, research indicates there are various other issues, which can act as barriers and inhibit the principal as he or she attempts to assess the skills of current teachers in the building and interview prospective teachers. Economic, contractual, and cultural barriers can prevent a principal from hiring or assigning teachers as needed within school buildings or throughout the district (Donaldson, 2013). These barriers can include such things as a school cultural expectation of tenured teacher placement in more choice classrooms as well as district budget issues, which can limit the ability of the principal to hire more-experienced teachers, both of which can possibly result in a principal's inability to place a highly effective teacher where needed the most (Donaldson, 2013). Another barrier can also be the lack of applicants or a small applicant pool sometimes faced by small rural districts when attempting to fill some positions (Ingle \& Rutledge, 2010). At the same time, principals are also faced with community and school board expectations, as well as faculty needs which can dictate some of the specific characteristics needed to "fit" the community (Budge, 2006). Budge points out that members of rural communities tend to have a very strong attachment to place and have expectations the school will reflect their culture and values (2006). As a part of social capital, "fit" must be considered when 


\section{PRINCIPALS’ PERCEPTIONS}

selecting future employees and for rural Missouri high school principals could make identifying and hiring highly effective teachers more challenging (Allan \& Catts, 2014).

\section{Existing Gap in the Literature}

Research indicates there is a possible disconnect or discrepancy between the perceptions of high school principals and the research available on the most valuable characteristics of a highly effective teacher. Research conducted by Torff and Sessions $(2005,2009)$ suggests principals perceive the characteristics of ineffective teachers to be pedagogical weaknesses, such as lesson planning and implementation, as well as weaknesses in classroom management as the most important factors. A much more recent study conducted by Nixon, Packard, and Dam (2016) also shows principals identified lack of instructional skills as the most common indicator of an ineffective teacher which seems to support the earlier findings of Torff and Sessions $(2005,2009)$. All three studies showed principals' perception of ineffective teachers put weaknesses in content knowledge as the least important factor (Nixon, Packard, \& Dam, 2016; Torff \& Sessions, 2005, 2009).

This contradicts extensive research, which identifies strong pedagogical skills, pedagogical content knowledge, as well as strong content knowledge as important characteristics of a highly effective teacher (Shulman, 1986; Grossman, 1990; DarlingHammond, 2000; Darling-Hammond et al., 2012; Darling-Hammond et al., 2005). Studies conducted by John Hattie $(2003,2009)$ support these results and include the idea that teachers with the ability to help students tie prior knowledge to new content knowledge is extremely important for closing the learning gap. His studies also identified positive student/teacher relationships and high levels of student engagement as 


\section{PRINCIPALS’ PERCEPTIONS}

important factors in a highly effective teacher's classroom (Hattie, 2009). Based on these characteristics, studies identify that principals may not perceive all of the same qualities of a highly effective teacher as identified by the research. School districts expect principals to identify the characteristics of a highly effective teacher while conducting observations to assess skills of current teachers and throughout interview processes when hiring new teachers. While there are many methods of evaluating teachers used in the state of Missouri, this study focuses on the perceptions of the principals as they attempt to identify effective teachers prior to and after hiring and is not a study of the evaluation process or method.

\section{Purpose of the Study}

Since the most common type of high school in Missouri is rural, the purpose of this study was to discover what qualities, characteristics, and skills rural Missouri high school principals perceive teachers must possess to be highly effective. This study focused on the perceptions high school principals have of the characteristics of highly effective teachers during observations of current teachers and during an interview for hiring purposes. Understanding the perceptions of principals as they observe current teachers and or work through the process of hiring new teachers could help increase the likelihood school districts will hire and retain the most effective teachers for their classrooms to have the most impact on the learning gap. Through this study, rural Missouri high school principals may gain some insight into their perceptions and an awareness of the impact these perceptions have on the process of identifying highly effective teachers. One very important responsibility of the rural Missouri high school principal is to employ and retain highly effective teachers to provide an excellent 


\section{PRINCIPALS’ PERCEPTIONS}

education for all students. This is especially important in rural communities where the number of available teachers may be small. Retaining highly effective teachers already in the classroom and identifying highly effective teachers to hire for open positions could become even more challenging.

Any discrepancy between what the current literature tells us and what this study may discover principals perceive as the characteristics of a highly effective teacher, could help to improve high school principals' ability to identify highly effective teachers. In addition, by analyzing the perceptions of the principals during the interview process we may uncover strengths or weaknesses in the district hiring process, which may help or hinder the ability to identify highly effective teacher applicants. These two aspects go hand in hand when they are able to identify existing highly effective teachers and then hire highly effective teachers for open positions principals can reduce the achievement gap and provide all students with an opportunity at an excellent education.

\section{Research Questions}

The research questions, which guided this study were,

- What do rural Missouri high school principals perceive to be the qualities, characteristics, and skills of a highly effective teacher in their buildings and do their perceptions align with current research on effective teachers?

- What are the qualities high school principals look for when hiring teachers, and how do these principals' expectations align with current research?

These questions focused and drove the framework and design of the study. 


\section{PRINCIPALS’ PERCEPTIONS}

\section{Conceptual/Theoretical Framework}

Identifying and hiring highly effective teachers is the rural Missouri high school principal's most important human resource responsibility. Viewed through the human resource frame, the rural Missouri high school is an organization, which exists to serve the needs of the community and relies heavily on the community and surrounding area to supply the talent and resources it needs to operate (Bolman \& Deal, 2008; Reininger, 2012). According to Bolman and Deal (2008, p. 122), the human resource frame relies on several key assumptions,

- "Organizations exist to serve human needs rather than the converse."

- "People and organizations need each other. Organizations need ideas, energy, and talent; people need careers, salaries, and opportunities."

- "When the fit between individual and system is poor, one or both suffer. Individuals are exploited or exploit the organization-or both become victims."

- "A good fit benefits both. Individuals find meaningful and satisfying work, and organizations get the talent and energy they need to succeed."

These assumptions put a great deal of emphasis on the "fit" of individuals in an organization and in rural Missouri high schools, finding this "fit" is the responsibility of the principal. School boards and community voters determine the hiring guidelines established for the school district and these usually strongly reflect the beliefs of the community at large (Budge, 2006). Along with the human resource framework, this study will use social capital theory to understand the idea of the best "fit" for a building or a specific teaching position. This concept has many definitions but essentially includes the importance of connections within the organization and between the 


\section{PRINCIPALS’ PERCEPTIONS}

organization and the outside community, which can contribute to the strength of the organization (Allan \& Catts, 2014; Putnam, 1995). Rural Missouri high schools, like other rural schools, are small communities within the larger community they serve and the community expects they will represent their beliefs and values as well as provide an excellent education to their children (Budge, 2006).

The challenge for rural Missouri high school principals is to first identify what qualities and skills a teacher must have to be considered highly effective and then fairly and accurately identify individual teachers in their schools based on these qualities and skills (Hallinger, Heck, \& Murphy, 2014). The role of the principal includes identifying, placing, and supporting highly effective teachers in every classroom. Being able to identify and support highly effective teachers currently in their classrooms may reduce the need to hire a large number of new teachers each year.

Beyond assessing the skills of current teachers, however, high school principals also have the responsibility of hiring new teachers to fill vacancies as they arise. This involves the ability to assess new applicants for the skills and abilities identified as the characteristics of a highly effective teacher. What do principals perceive and how do they identify the skills of a highly effective teacher while interviewing the applicant? To identify the principals' perceptions of a highly effective teacher, the researcher conducted interviews of eight rural Missouri high school principals who are directly involved in observing current teachers in their buildings and interviewing teachers to hire.

\section{Design of the Study}

The design of this study was as a qualitative case study which Merriam (2009, p. 40), defines as "an in-depth description and analysis of a bounded system". This case 


\section{PRINCIPALS’ PERCEPTIONS}

study focused on the perceptions of eight rural Missouri high school principals of the characteristics of a highly effective teacher. According to Merriam (2009), this design works best for this type of study since the unit of analysis includes eight participants from very similar settings, with a focus on their perceptions of effective teachers. The researcher gathered the information through semi-structured interviews and analyzed the data in an attempt to understand the perceptions of these eight participants

\section{Setting}

The setting for this study was chosen based on data from the Missouri Department of Elementary and Secondary Education (DESE) website which identified the small rural school as the most common type of high school in Missouri with 9-12 student populations of less than 500 (DESE, 2016). The setting for this study included eight rural Missouri public high schools with a population of 200-500 students in grades 9-12, and within a 40-mile radius of the researcher's location. Research also indicates $85 \%$ of teachers tend to work in districts 40 miles or less from their hometowns, which could create a common pool of teachers and teacher applicants for principals within this radius (Boyd, Lankford, Loeb, \& Wickoff, 2005; Reininger, 2012). Choosing schools within a 40-mile radius of the researcher's location could also increase the possibility principals have interviewed some of the same teacher applicants. High school principals are responsible for hiring, observing, and placing a highly effective teacher in every classroom. Understanding the perceptions of the principals as they conduct these observations and interviews could bring to light any discrepancies, which might exist, between what the literature describes as a highly effective teacher and the perceptions of the principals involved in this study. Through semi-structured interviews of principals 


\section{PRINCIPALS’ PERCEPTIONS}

directly involved in observing current teachers and hiring future teachers, the researcher gathered data on their perceptions of the qualifications of a highly effective teacher. Currently the literature shows a possible disconnect or discrepancy between what the principals perceive as the skills of a highly effective teacher and what the research reflects.

\section{Participants}

The participants of this study include eight Missouri public high school principals who had at least three years of experience observing classroom teachers and hiring teachers. Missouri Initial Administrator certificate is valid for four years with the first three years considered as the learning period for acquainting themselves with the ins and outs of a new position and the culture of the school (DESE, 2016). At the end of the fourth year, the principal may apply to upgrade to the Transition Administrator Certificate (DESE, 2016). These participants were a small purposive sampling of Missouri high school principals from rural school districts, who have at least three years of experience as a principal, and who are directly involved in the observation and interview process in their districts. The researcher used the Missouri Department of Elementary and Secondary Education (DESE, 2016) website, which includes location, student population, as well as other demographic information of all public school district buildings in the state of Missouri, to choose the school districts for this study. Using this information, the researcher identified thirteen school districts meeting the criteria identified for this study, as well as acquired essential district contact information. The researcher contacted all thirteen principals via email to explain the goal of the research and request their participation in the study. Nine principals responded. One principal 


\section{PRINCIPALS' PERCEPTIONS}

was eliminated by the researcher due to lack of three years of experience as a high school principal which left eight participants for the study. All eight principals who agreed to participate in the study met all established criteria and were vetted before the study began. All principals received a detailed description of the study, all important contact information, an explanation of rights as participants, as well as information about the complete confidentiality of all information collected for this study, which could identify them as participants. (Appendix A)

All eight schools involved in this study were rural by description according to NCES (2006) and within 15 to 35 miles of a larger town or city. The average 9-12 student body population of the participating schools was 365 with an average of 26 teachers, which created an average of a 14 to 1 teacher/student ratio (DESE, 2016). The demographic data shows a very homogeneous student body with an average of $98 \%$ of the student-body identified as white (DESE, 2016). These schools do differ economically, however, as indicated by the number of students who qualify for the Free and Reduced Lunch program, as determined by student family income. The data shows these schools range from as low as $11 \%$ to as high as $50 \%$ of their students qualifying for the Free and Reduced Lunch Program. In reviewing this data and the location of the schools, there seems to be a connection between the level of need and the distance from a larger town or urban area. The most rural schools, which had the least access to a larger town or urban area, generally had more students who qualified for this program.

Research indicates student poverty can academically affect the success of students in the district and emphasize and even greater need for highly effective teachers (Leithwood, 2010). 
PRINCIPALS' PERCEPTIONS

See Table 1 for a detailed description of the participants.

Table 1. Participants in the Study

\begin{tabular}{|l|l|l|l|l|l|l|}
\hline $\begin{array}{l}\text { School } \\
\text { Principal }\end{array}$ & $\begin{array}{l}\text { Years of } \\
\text { Experience } \\
\text { of the } \\
\text { Principal }\end{array}$ & $\begin{array}{l}\text { Number } \\
\text { of } \\
\text { Teachers }\end{array}$ & $\begin{array}{l}\text { Number of } \\
\text { Students in } \\
\text { grades } \\
9-12\end{array}$ & $\begin{array}{l}\text { Student } \\
\text { Teacher } \\
\text { Ratio }\end{array}$ & $\begin{array}{l}\text { Free and } \\
\text { Reduced } \\
\text { Lunch \% }\end{array}$ & $\begin{array}{l}\text { Demographics } \\
=\% \text { Caucasian } \\
\text { Students }\end{array}$ \\
\hline A & 11 & 23 & 430 & $18.6 / 1$ & 11 & 98 \\
\hline B & 10 & 19 & 280 & $14.7 / 1$ & 50 & 98 \\
\hline C & 9 & 36 & 499 & $13.8 / 1$ & 13 & 94 \\
\hline D & 7 & 28 & 375 & $13.4 / 1$ & 35 & 98 \\
\hline E & 6 & 30 & 405 & $13.5 / 1$ & 22 & 96 \\
\hline F & 8 & 18 & 240 & $13.3 / 1$ & 43 & 99 \\
\hline G & 4 & 32 & 380 & $12 / 1$ & 20 & 100 \\
\hline H & 8 & 24 & 308 & $12.8 / 1$ & 38 & 100 \\
\hline & Avg $=7.87$ & Avg $=26$ & Avg $=365$ & Avg $=14 / 1$ & Avg $=29 \%$ & Avg $=97.87 \%$ \\
\hline
\end{tabular}

The average years of experience of the participating principals was 8 years as head principal and over 20 years of experience in education overall. At least $30 \%$ of the principals reported having taught in the district or a similar district nearby when they were in the classroom themselves, which likely had some impact on their perceptions of highly effective teachers. Anecdotal data collected from the principals during our conversations also revealed that anywhere from 41 to $47 \%$ of the teachers in these districts are district graduates or graduated from a nearby community within forty miles of the school. For these districts, this is much lower than the $85 \%$ indicated by research (Boyd et al., 2005; Reininger, 2012). This could be a reflection of a shortage of teachers coming from these areas and the need for these districts to cast a wider net when looking for teacher candidates to fill open positions. This information could influence the analysis of the data on perceptions of principals as they interview teacher candidates.

The researcher will need to focus on the specific characteristics identified by the principal 


\section{PRINCIPALS’ PERCEPTIONS}

as effectiveness and not on the challenges principals face in finding candidates to interview and potentially hire.

\section{Data Collection Tools}

Data collection began with semi-structured interviews of high school principals who were directly involved in the process of hiring and observing high school teachers. The purpose of the interviews was to identify what principals perceive as the characteristics of a highly effective teacher during the observation and interview process. This will be compared to what the research says are the characteristics of a highly effective teacher to determine if there are any disagreements between the principals' perceptions and research data. With the permission of the principal, the researcher recorded the interviews and took notes throughout to ensure accurate collection of data. As noted by Merriam (2009), the semi-structured interview formats "assume that individual respondents define the world in unique ways" (p. 90). Each individual principal has a unique experience to share and using a less structured interview allows the researcher to dig deeper into individual perceptions. Using a semi-structured interview process gave the researcher the opportunity to collect similar demographic and background information from all participants while allowing for questions that are more open-ended to guide the interview and truly access the perceptions principals have of a highly effective teacher. The scheduling of all interviews was at the convenience of the principal, and each interview lasted approximately forty-five minutes to an hour. The researcher interviewed three of the eight principals in person in their high school offices and interviewed five principals over the phone. To avoid bias in the interview questions, a small number of principals who were not participating in this study, and who had direct 


\section{PRINCIPALS’ PERCEPTIONS}

experience in observing and hiring teachers were asked to evaluate the interview questions prior to the scheduling of interviews for research purposes. (Appendix B)

\section{Data Analysis}

The researcher transcribed interview recordings as quickly as possible following each interview to ensure that notes and memory could assist in deciphering any garbled or unclear recordings. Analysis of these transcriptions began immediately and was ongoing throughout the research process, which allowed for more focused data collection and improved the quality of data collected from later interviews (Bogdan \& Biklen, 2007). The researcher used a constant inductive and comparative analysis method to identify small pieces of information and analyze the data as it was collected, which meant stopping periodically and highlighting key words and phrases during transcription and immediately upon reading the entire typed transcript (Merriam, 2009). Using this systematic process of collecting small pieces of information along the way, the researcher transcribed each recorded interview and then read over the transcript to make notes and comments in the margins about interesting data that seemed important to the study (Merriam, 2009). The researcher began by highlighting and noting key words and phrases used by principals to identify the characteristics of highly effective teachers. The researcher repeated this process with each transcription and began to compare the notations between transcriptions while looking for any emerging themes in the characteristics identified by principals. After completing all transcriptions and reviewing all of the data, the researcher began to organize the notes into groupings of words that fit specific concepts or skills identified along the way. This open coding analysis process 


\section{PRINCIPALS’ PERCEPTIONS}

was the foundation for creating categories of data, which answered the research questions (Merriam, 2009).

Since the researcher is a high school teacher and department chair, the researcher paid special attention to the analysis process to be aware of any personal biases, which could negatively affect the accurate analysis of the data and presentation of the results. The researcher closely monitored personal assumptions about the characteristics of a highly effective teacher throughout the collection and analysis of the data to control for a possible bias. While analyzing the data, the researcher relied on the current research description of a highly effective teacher to avoid any personal opinions, which may have an effect on the analysis process. The goal was to remain objective and open-minded to the data as the themes and categories emerged.

\section{Limitations, Assumptions, and Design Controls}

This case study was limited to eight rural Missouri high schools with a very similar student body. The results may vary if conducted in large urban schools, or in schools with a much higher level of poverty, where principals may face a more diverse population and possibly less cohesive urban communities and could indicate a need for teachers with a different set of skills to be effective. Other limitations of this study include the fact the researcher is currently a Missouri high school teacher and a department chair, which makes her an "insider" to the system. As a high school teacher, the researcher is subject to observation by a principal and understands the challenges faced by classroom teachers to see an observation as a productive learning opportunity to grow and improve. There may have been less bias by the researcher if the setting for this study had been either elementary schools or middle schools since the researcher is much 


\section{PRINCIPALS' PERCEPTIONS}

less familiar with either of these settings. As a department chair, the researcher is responsible for giving guidance and support to department members as needed. This support could include both content knowledge and pedagogical skill, which gives the researcher the opportunity to understand the classroom from the point of view of the principal as well as the teacher. The researcher tested the interview questions with principals who had experience conducting teacher observations and interviews, and who were not participating in the study, to find flaws or a bias in the questions. As a design control, the researcher conducted all interviews using the same set of interview questions as a guide and with permission, recorded all interviews. This assisted in a more accurate analysis of the data and allowed the researcher to return to the interview itself and not just the written interview notes when necessary. It was helpful, at times, to return to the tape to listen to the conversation to clarify the context of a comment in the transcript, as well as to reconnect with the tone of the interview, which helped to analyze what the principal was actually saying.

\section{Definitions of Key Terms}

Every Student Succeeds Act - Legislation passed in 2015, which updates the expectations established by NCLB (2001). Most of the responsibility for creating and implementing accountability systems returned to the states with the expectation that state systems would continue to meet federal parameters already in place.

Free and Reduced Lunch Program: A program designed to provide meals for lowincome students, which is determined through a calculation based on the annual federal poverty line established by the federal government. Traditionally the Free and Reduced Lunch statistic is used to track the number of students living in poverty in school districts. 


\section{PRINCIPALS’ PERCEPTIONS}

Highly Effective Teacher - For the purpose of this study, a highly effective teacher is defined as someone who has strong pedagogical knowledge, pedagogical content knowledge, and subject content knowledge to reach and teach all students. Each of these is individually defined below.

No Child Left Behind Act of 2001 - Reauthorization of Elementary and Secondary Education Act passed by Congress in 2001. The main premise of this Act was to ensure that all students would reach proficiency or better levels of achievement by school year 2013-14. This was to be accomplished through the implementation of standards and assessments, a focus on accountability and annual yearly progress, and the use of corrective action when schools were failing. The Act also included requirements for staff qualifications and allowed for more parental involvement and choice in education for their children.

Performance-Based Teacher Evaluation: A common form of teacher evaluation used in Missouri, which includes principal classroom observations, teacher-principal conferencing, and self-evaluation to improve the skills of teacher in the classroom.

Pedagogical Content Knowledge: "The blending of content and pedagogy into an understanding of how particular topics, problems, or issues are organized, represented, and adapted to the diverse interests and abilities of learners, and presented for instruction" (Shulman, 1987, p.8).

Pedagogical Knowledge: Generally focuses on the classroom management knowledge and skills of the teacher. It includes but is not limited to, behavior management skills, the ability to create a positive, open, engaging learning environment, as well as teacher reflection on best practices in the classroom. 
PRINCIPALS' PERCEPTIONS

Rural High School: A high school located within a rural area, defined by the National Center for Education Statistics as an area five miles or more from an urbanized area (NCES, 2006).

Subject Content Knowledge: The quantity and quality of subject matter in the mind of the teacher.

\section{Significance of the Study}

The present study will contribute to theory and practice related to assisting principals in understanding how their perceptions impact the identification and retention of highly effective teachers already in their classrooms, as well as assist in identifying and hiring highly effective future teachers. This is extremely important in an environment of ever changing policy and legislation at the federal as well as state level on the expectation all teachers will be highly effective. Improved teacher and principal preparation programs could result from the information gathered from this study, which could better inform teachers and principals on the characteristics needed to have highly qualified teachers in all classrooms. For rural Missouri high school principals, this could also help to improve their ability to identify and retain highly effective teachers for their school.

\section{Scholarship}

Having a highly effective teacher in every classroom is extremely important for the success of all students. More information needs to be available on the perceptions of principals as they assess the skills of current teachers and interview future teachers when attempting to identify those who are highly effective. Extensive studies have identified the most important characteristics of a highly effective teacher and the impact this teacher 


\section{PRINCIPALS’ PERCEPTIONS}

can have on student success. More specific research data available on the perceptions of rural high school principals of an effective teacher could help to increase awareness of a possible discrepancy between what the research says and what the principals perceive. It could also put a focus on the needs or demands that may be unique to the rural high school setting in identifying highly effective teachers. Results of this study will increase information and could potentially encourage further research into the importance of the perceptions of the principal as the link between the highly effective teacher and placement in a classroom.

\section{Practice}

It is important to know if there are any discrepancies between what principals currently perceive to be the qualities of a highly effective teacher who is successful in closing the learning gap and what current research describes as a highly effective teacher. Any discrepancies that come to light could help school districts improve not only how they assess the skills of current teachers but also help them provide better professional development opportunities for principals and teachers which are directed at improving these skills. Professional development is an important component in this and all school improvement efforts. This information will also create an opportunity for school district principals and teachers to have a serious conversation about the skills and abilities highly effective teachers must have to close the learning gap and increase student growth. This may be especially important to rural school districts where the supply of teachers can be more limited. Educating the school board, superintendent, and other key community members on the characteristics of a highly effective teacher could also improve the principal's ability to identify and hire highly effective teachers. 


\section{PRINCIPALS’ PERCEPTIONS}

The importance of this study is to put a specific focus on the actual skills and abilities as perceived by principals, which represent a highly effective teacher. If principals can accurately identify these teacher qualities and skills, they will be able to assess teachers fairly, and work to support, or not hire, those who are not designated as effective (Hallinger et al., 2014).

\section{Summary}

Fairly assessing the skills of teachers is extremely important to ensure those who are truly highly effective and able to close the learning gap are hired and retained. Knowing and being able to identify characteristics and skills highly effective teachers must possess to ensure student growth and close the learning gap would help school districts hire and retain the best teachers. School districts and individual teachers are accountable for the skills of the graduating students (NCLB, 2001; ESSA, 2015). This requires students have access to the best-trained teachers in all classrooms across all districts. Lack of accessibility to great teachers for the students who need them the most is a huge challenge across the nation. There is a great deal of effort in schools now to increase the equity of access for students with challenges, especially poverty. College and career ready students are the result of highly effective education and school districts must be able to identify the teachers who can successfully generate these results. 


\section{PRINCIPALS' PERCEPTIONS}

SECTION TWO:

PRACTITIONER SETTING FOR THE STUDY 


\section{PRINCIPALS’ PERCEPTIONS}

\section{Introduction}

As the leader of the school, principals play an extremely important role in the presence of highly effective teachers in classrooms in their schools. In rural Missouri high schools assessing the skills of current teachers and interviewing future teachers is the responsibility of the head principal. They make recommendations to the superintendent and the local school board on who to retain and who to hire for each new school year. For this reason, they are an extremely important link in placing an effective teacher in every classroom.

\section{History of Organization}

Public education has been a norm in Missouri for decades, the structure of which has changed little in that time. With slight adjustments, traditional bell schedules and yearly calendars are still close to what they were thirty years ago in many of these schools. Most rural Missouri high schools continue to have a traditional six or seven period day, which begins sometime around eight a.m. and ends around three p.m., as well as a traditional calendar year beginning in mid-August and ending in mid-May.

Principals in these schools continue to be the administrative leadership in charge of the business of the school, student discipline issues, as well as instructional oversight in the classrooms, which today, includes the effectiveness of the teaching staff. These rural Missouri schools also have a rich history of traditions they maintain and many people who live in these communities are graduates of the school, which could have an impact on the high school as an organization as well as the principal as the leader of the organization. The structure of the rural Missouri high school and the connection of the school to the community is an extremely important part of the setting for this study, 


\section{PRINCIPALS’ PERCEPTIONS}

especially since the rural high school of less than 500 students is the most common type of high school in Missouri (NCES, 2006).

\section{Organizational Analysis}

\section{Structural Frame}

The rural Missouri high school when viewed through the structural frame is best described as a professional bureaucracy (Mintzberg, 2005; Bolman \& Deal, 2008). This type of structural frame includes the characteristics of a large operating core, a small number of middle managers, control generated through indoctrination and professional training, slow response to external change, and individuals who strive to improve while the overall institution changes slowly (Bolman \& Deal, 2008). The rural Missouri high school is a professional bureaucracy with a large operating core of teachers, who far outnumber the middle management personnel. Middle management responsibilities usually fall to a head principal and possibly an assistant principal if the school is large enough to support this position. These principals have the job of overseeing what all teachers do in the classroom, which means they rely heavily on the core to carry out expectations as laid out by the district superintendent and school board without much direct oversight. Due to their tenured status, some teachers have a greater degree of autonomy to do what they believe is best for students, which can make it difficult for a principal to implement necessary changes to the structure and culture of the school (Donaldson, 2013). Tenured teachers have more security in supporting or resisting changes introduced by

administration and feel more comfortable voicing their opinions which can undermine the position of the principal (Donaldson, 2013). 


\section{PRINCIPALS’ PERCEPTIONS}

As a professional bureaucracy, individual teachers and/or principals can work to gain additional degrees and improve their individual skills but overall the structure of the day and the content taught in these schools changes very little. Once hired, on the job training and mentoring indoctrinates the new teachers in the traditions and processes of the high school. To make significant changes in a professional bureaucracy, the operating core must have buy in and must be the initiative behind the change if it is to be a lasting one (Bolman \& Deal, 2008). This structure can challenge the ability of the principal to identify and place highly effective teachers where needed most in the high school.

\section{Human Resource Frame}

A second frame, which applies well to the rural Missouri high school, is the human resource frame. This frame focuses on the connection between the people and the organization as well as other existing relationships (Bolman \& Deal, 2008). This frame is based on the assumptions organizations exist to serve human needs, people and organizations need each other, and when the fit between an individual and an organization is poor, one or both suffer (Bolman \& Deal, 2008). This frame also includes the idea organizations work to find and retain people with the skills to do the work as well as the right attitude to be a good fit for the organization (Bolman \& Deal, 2008). Rural Missouri high schools exist to serve the local community and educate the children to be productive citizens of the community they serve. The responsibility of educating students for successful futures requires trust between the community members who are sending their children and the school personnel responsible for providing an excellent education. This trust is easily lost if the reputation of the school declines and 


\section{PRINCIPALS' PERCEPTIONS}

can hurt all parties involved. Many times small rural communities prefer to see local people they know and trust working in their schools (Budge, 2006). The perception is they are a better fit for the school and the community, which at times may be a challenge for principals of rural high schools.

Principals are the instructional leaders in schools who are responsible for assessing the skills of all teachers, which includes identifying those who are or are not highly effective who are already in the classroom, as well as hiring highly effective future teachers. This is a large portion of the responsibilities assigned to high school principals and requires strong leadership skills if it is to be done accurately and appropriately. The skill of the principal as leader of the school can determine the overall morale of the personnel and be the deciding factor between the school as a strong cohesive organization or a dysfunctional team (Northouse, 2013). At the same time, the professional bureaucratic structure of rural high schools and the expectation that principals will find the right "fit" for open positions requires a great deal of leadership ability and skill.

\section{Leadership Analysis}

To understand the challenges principals face as leaders in their schools, we must first understand and attempt to define the concept of leadership. This is a very difficult task to accomplish, since the literature contains many definitions and concepts of what leadership is which have evolved over the years. This study will focus on the situational approach as well as transformational leadership as key tenets of the skills and abilities

rural Missouri principals must possess to work well with a wide variety of personnel and in small communities where trust and common values are important (Budge, 2006; Northouse, 2013). To understand the leadership challenges principals face as 


\section{PRINCIPALS’ PERCEPTIONS}

instructional leaders, however, we must review the many different approaches and styles of leadership identified by research.

In a review of the literature conducted by Northouse (2013), he summarized the challenges faced by modern researchers to identify and define leadership. Historically, the literature reveals that the descriptions and definitions of leadership over the last century of study have shifted from a focus on control and power in the early twentieth century, to the inclusion of individual traits and influence on groups in the 1940's, to a general shift to organizational behaviors in the 1970's (Northouse, 2013). Since the 1970 's, researchers have continued to add to the wealth of information on the nature, skills, and abilities of leaders however, there is still no definitive agreement on a single definition of leadership (Northouse, 2013).

After reviewing the literature on leadership, Northouse (2013) proposed there were four common components involved in all definitions and concepts of leadership. These four central components are process, influence, the existence of groups, and common goals, and with this in mind; he defined leadership as a process whereby an individual influences a group of individuals to achieve a common goal (Northouse, 2013). Similarly, according to Kotter (1990/2011), leaders set a direction, develop a vision and then align people to implement the vision. Collins (2001/2011) describes a leader as someone who must be able to create a culture of discipline with the right people in the right positions to lead an organization toward change. All three definitions or descriptions incorporate the four components pointed out by Northouse (2013), however, both Kotter (1990/2011) and Collins (2001/2011) are more specific about the leaders role in aligning people or ensuring the correct people are in the right positions to make 


\section{PRINCIPALS’ PERCEPTIONS}

change, which is a very important part of the role of principals. Rural Missouri high school principals shoulder the majority of the responsibility of putting the right people in the right positions through the observation and interviewing process to ensure a highly effective teacher is in every classroom.

While these definitions or descriptions can guide us as to what leadership is there are still many different perceptions or styles of leadership proposed in the literature today. According to Bolman and Deal (2008), leadership is not tangible, "It exists only in relationships and in the perception of the engaged parties" (p. 343). By this very description, it implies the perception of leadership is different from person to person, situation to situation, and researcher to researcher, and includes a wide variety of characteristics and skills. As the leaders in a school, principals face the many challenges of creating relationships and leading a diverse population of people on a daily basis. How a principal carries out this process of leadership requires some reflection on their own style of leadership, which includes their strengths and weaknesses, as well as their goals and expectations if they plan to be successful leaders (Marsh, 2010; Northouse, 2013).

One of the most researched models of leadership is the trait approach or model. Studies of this approach to leadership began in the early $20^{\text {th }}$ century when researchers attempted to identify the innate characteristics a person possessed which made them a great leader and set them apart from their followers (Bass, 1990). This approach focused on only the qualities with which a leader was naturally born. In the late 1940's, Stogdill's research continued to support the idea of inborn traits as characteristics of leadership; however, he added the concept of situation to the trait model, suggesting that 


\section{PRINCIPALS’ PERCEPTIONS}

traits found useful in one situation may not be as useful in another (as cited in Northouse, 2013, p. 19). Over the years, researchers have been unable to agree upon a single list of traits that all leaders must possess; however, a few of the traits, which appear in much of the research, include intelligence, self-confidence, determination, integrity, and sociability (Northouse, 2013). A more modern take on trait model of leadership is the recent research into the charismatic leader. Research identifies this type of leader as someone who possesses the traits of self-monitoring, self-awareness, and self-evaluation as a more modern take on the trait model of leadership (Jung \& Sosik, 2006). This research also includes the ideas that charismatic leaders manage the impressions others have of them and are individuals who are motivated to attain self-actualization (Jung \& Sosik, 2006). Similar to trait approach, this style or type of leadership relies on inborn characteristics of the individual leader.

Positives of the trait leadership approach for high school principals and other education leaders is that it encourages the development of special qualities or traits they already possess as leaders. In addition, it has been widely studied and focused on the leader and the leadership process (Northouse, 2013). At the same time critics point out the lack of a set identifiable agreed upon list of traits for all leaders, the concept of situation is usually left out of this research, the traits listed as most important are usually very subjective to the researcher and finally, this approach is not useful as a method for training leaders (Levi, 2014).

A second approach to leadership is a focus on skills instead of traits. Work by Robert Katz in the 1950's shifted the focus from leadership traits to leadership skills. Katz proposed that the necessary leadership skills required for effective leadership were 


\section{PRINCIPALS’ PERCEPTIONS}

"technical, human, and conceptual skills" (as cited in Northouse, 2013, p. 43). Technical skills are knowledge and ability in a specific type of work (Northouse, 2013). For example, in education a principal must have the technical skills related to leading a school in decision making for long and short-term goals, observing and hiring highly effective teachers, as well as conducting student discipline as necessary. Human skill is knowledge about and ability to work with people who are a part of the leaders work responsibilities (Northouse, 2013). According to Katz, this skill includes the ability to understand the perspectives of others as well as an awareness of one's own perspective as the leader (as cited in Northouse, 2013, p. 45). For principals, this skill would be extremely important since the bulk of their work responsibilities require interaction with other people, including students, teachers, other principals, the superintendent, board members, as well as parents and other community members. Interacting with so many different people is one of the most complicated parts of the responsibilities of all who are involved in education and it requires a keen awareness of your own perspectives in all interactions with others. The final skill identified by Katz is conceptual which includes the ability to create a vision and help others understand the goals of an organization (as cited in Northouse, 2013, p. 46). In education, this is also a crucial skill since many goals and reforms are framed in abstractions and are difficult to understand (Marsh, 2010). As a leader, the principal must be able to help teachers and other stakeholders in the district see the goals in a more concrete way and help clarify the vision (Northouse, 2013).

More recent research on the skills approach to leadership adds the concept of capabilities, which includes an emphasis on knowledge and skills as the most important attributes of leadership. (Mumford, Zaccaro, Harding, Jacobs, \& Fleishman, 2000; 


\section{PRINCIPALS' PERCEPTIONS}

Northouse, 2013) Because of this study, the researchers created a five-part skills model, which includes problem solving skills, social judgment skills, and knowledge as the competencies necessary to achieve desired outcomes (Mumford et al., 2000; Northouse, 2013). Like Katz, there is an emphasis on the need to understand and work with others to be a successful leader. The basic concept of this approach for principals is the ability to apply empathy to a situation, understand what motivates others, as well as having the skills to communicate their own point of view during the decision making process. This is especially true when implementing a mandated change such as the teacher evaluation guidelines introduced by Missouri Department of Elementary and Secondary Education in 2013. Being able to understand the perspective of the teacher is a valuable tool for the principal in this situation.

According to Northouse (2013), the positive side of the skills approach is its focus on developing skills and the idea it makes leadership roles available to all who work to acquire the skills if they choose to do so. The critics of this approach, however, point out that some identified leadership skills are actually traits and the research does not explain how the identified skills make a good leader (Northouse, 2013).

Another long-held approach to leadership is situational leadership and as its name implies, the focus of the research is on leadership in different situations (Northouse, 2013). This style or approach requires that leaders match their style to the level of ability and dedication of the followers (Northouse, 2013). In education, this particular approach would be very useful for a principal when choosing how to work with various teachers he or she observes. A young teacher, new to the school, may need a higher level of direction and support than a veteran classroom teacher may need. A veteran teacher, however, 


\section{PRINCIPALS’ PERCEPTIONS}

may need more support with less direction when learning to implement a new skill such as using technology in the classroom, which is expected by the administration. The situational leadership model created by Blanchard and Hersey in 1969 and refined in 1985 by Blanchard identifies four categories or styles based on the needs of the followers (as cited in Northouse, 2013, pp. 99-100). The four categories include directing, coaching, supporting and delegating (Northouse, 2013). Choosing the appropriate style is determined by accurately assessing the situation and the needs of the followers in each situation. This approach may be a useful leadership method or style in education for a principal who moves from room to room observing and assessing the skill and abilities of a wide variety of teachers. As he or she gets to know the needs of each individual teacher, the principal may have to adjust how they work with each teacher. Contingency theory is a very similar area of research, which also supports the idea of the importance of understanding the impact of a situation on the leader and the style of the leader. According to Fiedler, effective leadership is dependent upon matching the style of the leader with the situation (as cited in Northouse, 2013, p. 123). Research into situational and contingency theory of leadership maintains that leaders are not effective in every situation. This could be a challenge in a small rural school district where a building may have only one assigned principal to lead that building. If he or she does not possess the appropriate skills or traits for the situation there may be challenges to their leadership of that school.

Other more recent studies of leadership styles include transformational leadership which focuses on the needs of the followers to have someone interested in their personal feelings and values (Bryman, 1992; Taylor, 2009), and authentic leadership which 


\section{PRINCIPALS' PERCEPTIONS}

focuses on the needs of the followers for genuine, real, trustworthy leaders (Leroy, Palanski, \& Simons, 2012). Both of these areas of leadership study are a result of a changing society and followers who need leaders who are interested in their personal feelings, values and goals, as well as leaders who are ethical and have a high level of integrity. The uncertain world created by the attack of $9 / 11$ and the major scandals in big business over the last twenty years have created a world of uncertainty and a need for leaders who can be trusted (Northouse, 2013). Trust is difficult to build and easily destroyed and this is an especially difficult task for rural high school principals where communities are close knit and mistrust those who are seen as outsiders (Budge, 2006). Research into authentic leadership has increased since the 1990's with a goal to develop a true definition of this type of leadership, and as a result, several definitions with different perspectives exist at this time. The intrapersonal perspective says that an authentic leader is one who has self-knowledge and self-concept and is self-regulated (Shamir \& Eilam, 2005); while the interpersonal perspective says that authentic leadership is created through the collaborative efforts of the leader and the followers (Eagley, 2005). The final definition is the developmental perspective, which says that authentic leadership can be nurtured, developed over a lifetime, and is triggered by life events (Avolio \& Gardner, 2005). All of these various perspectives together describe a leader who is self-aware, cooperative, and empathetic, as well as grounded by life events. With the many changes and demands for accountability in education today, authenticity is very important for principals and teachers alike. Trust and collaboration are key elements in a successful working environment where the stakes are very high to provide a highly effective teacher for every classroom and an opportunity for all to access a high quality education. 


\section{PRINCIPALS’ PERCEPTIONS}

Ultimately, educators are responsible for making sure all students are successful in high school, prepared for some form of post-secondary education or training, and able to acquire work in their chosen career. This is a great responsibility, and having leaders who can create a vision of what the future of education should look like and then lead people to that vision is imperative. For principals, this includes hiring and retaining the most highly effective teachers for all classrooms. According to research conducted by Finnigan and Stewart (2009), clear communication of a vision is an extremely important part of strong principal leadership to achieve change. Principals who are successful at leading change are also able to provide on-going support for teachers, include collaborative structure and norms, as well as create a "commitment to collective goals" (Finnigan \& Stewart, p. 586).

Understanding one's leadership style and goals is important; however, principals must also be aware that in some instances making decisions collaboratively will increase the success of making meaningful changes and creating buy-in from stakeholders (Marsh, 2010). According to Hammond, Keeney and Raiffa (2006/2013), making decisions that cling to the status quo is safe and people believe they will avoid a possible mistake. Fear of the unknown still carries more weight even when data and statistics can show the success of making a change. For example, in education this type of fear is very apparent when you attempt to replace the traditional PBTE form of teacher evaluation. Even though data suggests most teachers do not find this form of evaluation helpful in improving what they do in the classroom, most resist changing to another form of evaluation (Looney, 2011). Because of these many challenges, it is necessary for principals and teachers to reflect on what works, what does not work, and what could be 


\section{PRINCIPALS’ PERCEPTIONS}

improved in the future to make changes that benefit the entire district over time.

Leadership is the key to this reflection process and overall improvements to the school district. It is also important to keep in mind the impact principals have on the school and the district through the selection and placement of teachers in high school classrooms. As the instructional leaders rural Missouri high school principals bear the bulk of the responsibility for ensuring current teachers as well as teachers they hire for open positions are highly effective to provide an excellent education for all students. As part of this study, the role of the principal is key to identifying and placing highly effective teachers where they are needed most.

\section{Implications for Research in the Practitioner Setting}

As the leader of the school, principals have a great deal of influence on the existence of highly effective teachers in classrooms in their schools. If principals are able to accurately identify the characteristics of highly effective teachers, as instructional leaders, they could help teachers hone and develop the skills needed to be highly effective. When hiring new teachers, principals could also work to develop the skills of young teachers to grow into highly effective teachers over time. At the same time, the challenges faced by the principal during the observation process are based on symbolic, traditional concerns as well as political issues, which could make it difficult for a principal to place a highly effective teacher where they are most needed in the school (Bolman \& Deal, 2008). Understanding the perceptions of principals as they carry out the process of assessing the skills of current teachers and interviewing prospective teachers could help to clarify what they identify as the characteristics of a highly effective teacher and assist in ensuring all teachers are highly effective. For rural Missouri high 


\section{PRINCIPALS’ PERCEPTIONS}

schools, having access to highly effective teachers for all students could improve the overall community and community support for the school district as a whole. The local school is the heart of the rural community and reflects the values and traditions of the constituents. For community members the strength of the school could determine the social and economic future of the rural community as a whole by providing the skills all students need to be successful in the future (Budge, 2006).

\section{Summary}

Principals are the leaders of the high school and they face many challenges in their role as they assess the skills of current teachers and interview prospective teachers for positions in the school. The traditional barriers to school change can make it very difficult for principals to identify highly effective teachers as well as place them in the most impactful position in the school. Policy-makers lean heavily on the leadership of school districts to implement the changes and reforms they mandate in an effort to improve the quality of our schools. Understanding their own strengths and weaknesses as school district leaders will assist principals in their many roles as leader of a school. 


\section{PRINCIPALS' PERCEPTIONS}

SECTION THREE:

SCHOLARLY REVIEW FOR THE STUDY 


\section{PRINCIPALS' PERCEPTIONS}

\section{Introduction}

Today there is an expectation by the community and local school board, as well as state and federal Departments of Education that rural Missouri high school principals will staff all classrooms with a highly effective teacher and all students will have access to an excellent education. Identifying and hiring highly effective teachers are important parts of the overall education system and can be challenging tasks for principals directly involved in the process. What principals perceive as the skills of a highly effective teacher while observing current teachers and interviewing prospective teachers is the focus of this research. This literature review begins with a brief overview of the reform efforts in education over the last several decades aimed at creating equal opportunity in education for all students, improving the evaluation process to create effective teachers, as well as early research on closing the learning gap. Following this is a review of the research on the impact of a highly effective classroom teacher on this gap. A review of the research into the role of the principal and the teacher evaluation process will follow. The final section will review the current literature available on the perceptions of principals on the characteristics of a highly effective teacher as they observe current teachers and interview prospective teachers in an attempt to place a highly effective teacher in every classroom.

\section{Reform Efforts, Teacher Quality, and Learning Gap}

The focus on effective teachers today hinges upon the goal of districts to improve education for all. The continued learning gap is of major concern as our nation becomes more and more diverse and the students from diverse, non-white, or lower socioeconomic backgrounds struggle to achieve success in our nation's schools (Holland, 


\section{PRINCIPALS' PERCEPTIONS}

2007). There continues to be a debate, however, over the causes of the learning gap. In 1964, Congress commissioned a study to determine the actual need for funding to improve equality of education for disadvantaged students. The released results of this study became known as the Coleman Report. This report to Congress placed the main cause of inequality in education on the background and family life of the students and minimized the effect of funding and school setting on the outcome for all students (Austin, 1979; Rojas-LeBouef \& Slate, 2011). This study did support the idea that education for all was extremely important; however, it minimized the effect of schools and teachers on the differences in the results of education for students from minority or low socio-economic situations (Austin, 1979; Rojas-LeBouef \& Slate, 2011). This report has had tremendous impact on attitudes toward education reforms over the years, even though, not all researchers supported the results or methods of this study as valid. Gamoran and Long (2006), identified many researchers who disagreed with Coleman and pointed to much larger differences within schools than between schools which did account for some of the gap in learning.

Continued research by those who criticized the Coleman Report resulted in data to support other causes for the learning gap. Research conducted by Klitgaard and Hall in 1973 focused on the small number of schools that were successfully closing the learning gap and the results of their study revealed that there was no one characteristic but a combination of factors that made these schools successful where others were not (as cited in Austin, 1979, pp. 11-12). From their research, Klitgaard and Hall created a list of factors for successful schools (as cited in Austin, 1979, pp.12). These factors included but are not limited to, such traits as strong participatory principal leadership, experienced 


\section{PRINCIPALS’ PERCEPTIONS}

principals, and teachers with appropriate education for their positions, as well as strong parent-teacher relationships and higher teacher expectations for all students to graduate and go on to college (as cited in Austin, 1979, pp.12). Additionally, Smith and Tucker described schools with the most consistent impact on closing the learning gap as having strong principals, creative, collaborative teachers who believe in the success of all students, and supportive parents (as cited in Austin, 1979, p. 14). In a more recent study, Noguera (2007) summarized the key characteristics and strategies of schools successfully helping all students learn as ones committed to engaging parents as partners in education, as well as having strong instructional leadership with curriculum supported by welltrained teachers, and reflective practices on interventions. Leithwood (2010) conducted an analysis of thirty-one scholarly research articles to gather information about the characteristics of school districts, which have been successful in closing the learning gap. According to his analysis of the research, some of the most important characteristics include a district-wide focus on student achievement, which includes the concepts of "closing the gap" as well as "raising the bar" (Leithwood, 2010). Other key characteristics include the development of student performance standards with district wide aligned curriculum, and effective use of data as evidence to plan and organize learning as well as a means of accountability for the district, and district-wide, highly valuable professional development for both teachers and principals (Leithwood, 2010). Research over the last few decades puts a great deal of emphasis on district cohesiveness, strong principal leadership, and well-trained highly effective teachers as necessary components in closing the learning gap (Leithwood, 2010). 


\section{PRINCIPALS’ PERCEPTIONS}

There is still debate, however, about the specific causes and solutions to dealing with the learning gap. An analysis of the data in the research literature conducted by Jencks and Phillips (1998) summarized a body of literature where family background, socioeconomic status, and school factors such as teacher quality were consistently used as the most common predictors of the learning gap. In an interview Richard Rothstein, a research associate at the Economic Policy Institute, contended that schools cannot solve the learning gap issue until other social problems like poverty, sub-standard housing, and health-care issues of students are also addressed by society (Holland, 2007). This continues to echo the results of the 1966 Coleman Report and illustrates the division and therefore the difficulties that exist in the movement to reform education and provide highly effective teachers for all students.

\section{Teacher Evaluations and Highly Effective Teachers}

Even though this study will not focus on the evaluation process, it is extremely important to include this research as part of the goal of improving education for all. There is a large body of research available on teacher supervision and evaluation as a means for improving instruction. In the early 1980's, Congress commissioned a study of the status of American schools and in 1983, the government released A Nation at Risk Report which revealed serious weaknesses in the American education system and rekindled public demand for an overhaul of this system. Researchers and educational leaders increased efforts to improve instruction through better teacher evaluation systems. Research conducted and works published by Lewis (1982), McLaughlin and Pfeifer (1988), as well as Gitlin and Smyth (1989), all sought to provide educational leaders with systematic guidance to evaluate teachers in a productive, structured manner which would 


\section{PRINCIPALS' PERCEPTIONS}

provide feedback to the teacher and improve activities in the classroom. This research laid the groundwork for the performance based teacher evaluation process that has been the basis of teacher evaluations for many years. Darling-Hammond, Wise, and Pease (1983), however, pointed out for teacher evaluations to be a useful tool to improving education the process needed to have a balance of both standardized performance expectations as well as a teacher-specific approach. At the same time, Shulman (1986) became concerned with what he saw as a decrease in the interest in the content knowledge of the teacher in teacher evaluations. His work focused on the importance of both the pedagogical skill of the teacher as well as their strength in content knowledge (Shulman, 1986). Grossman (1990) also identified through research, teachers with strong content knowledge as well as strong pedagogical content knowledge or the skill to teach the subject in a variety of ways were better prepared and more effective in the classroom.

Work by Millman and Darling-Hammond (1990), sought to clarify even further the intent and purpose of teacher evaluation as a collaborative effort by principal and teacher to enhance the quality of teaching in the classroom. Their research emphasized the use of multiple sources of data and evidence such as a portfolio to evaluate the skills of individual teachers rather than the reliance on principal observation as the only evaluation tool (Millman \& Darling-Hammond, 1990). In this case, the role of the principal was extremely important as a collaborator to improve instruction rather than as an evaluator of performance (Millman \& Darling-Hammond, 1990).

By the late 1990's, data did reflect efforts to improve teacher quality through a better evaluation process had resulted in some success in closing the learning gap. Data collection, however, continued to illustrate no state had been able to close the gap 


\section{PRINCIPALS' PERCEPTIONS}

completely in all districts (National Center for Education Statistics, 2013). The result of this was a further increase in federal efforts to put pressure on states to continue to improve education opportunities for all and close the learning gap. The No Child Left Behind (NCLB, 2001) legislation again expanded federal support for and influence over education and shifted the emphasis away from a focus on compliance with federal and state expectations to one of accountability for end results. NCLB (2001) mandated states would set standards of performance for both students and teachers. It included an expectation high-stakes tests be used to measure the growth in skills and abilities of students throughout their educational career, as well as to measure teacher effectiveness as a part of the evaluation process (NCLB, 2001). The goal of NCLB and later reaffirmed by the Every Student Succeeds Act (2015), was to ensure school districts place a highly effective teacher in every classroom and provide all students with access to a high quality education.

As a result of the failure to close the learning gap and NCLB legislation, research on teacher evaluation processes also shifted in the late 1990's and early 2000's. Researchers sought to find a way to quantify the skills of a highly effective teacher using student improvement data linked to high-stakes testing. Known as the value-added model, this method uses data to determine the skills of teachers in individual classrooms while controlling for things outside of the teachers control, such as the socio-economic differences in student backgrounds. Early research indicated teacher, school, and district value-added could be measured using student growth data and could control for outside factors such as socio-economic and family background (Sanders \& Horn, 1994; Meyer, 1997). A three-year study funded by the Bill and Melinda Gates Foundation, published 


\section{PRINCIPALS' PERCEPTIONS}

in 2013, continues to support the use of student achievement data as an accurate measure of effective teaching. This report advocated for the use of multiple forms of evaluation for improvement; however, it strongly supported the use of student scores on high-stakes tests as an important component of an accurate method of measuring the skills and abilities of teachers (Gates Foundation, 2013). Not all agree, however, that this is the most accurate measure of effective teaching.

Other research into the use of high-stakes testing and evaluation systems that focus more on accountability based on test results point out they may be counterproductive to providing an opportunity for teacher improvement since teachers may be less likely to reveal weaknesses or ask for help from colleagues or principals (Looney, 2011). In addition, according to Jackson and Bruegmann (2009), there is growing evidence that teachers who collaborate and learn from each other about improving instruction are much more effective in the classroom. This requires a great deal of openness and trust between teachers that might be limited in an atmosphere of accountability. Research conducted by Finnigan and Gross (2007) identified teachers as more driven by the desire to help students than by the promise of rewards or punishments commonly tied to the value-added model of teacher evaluation or merit pay. This study also identified the potential counterproductive, negative effect high-stakes accountability policies could have on the motivation and morale of teachers over time (Finnigan \& Gross, 2007). According to Looney (2011), teacher evaluation should be balanced between accountability and teacher improvement. For improvement to take place the evaluation process should take into consideration the ever-changing world of education and the need for teachers to continuously update knowledge and skills to better meet the 


\section{PRINCIPALS’ PERCEPTIONS}

needs of diverse students (Looney, 2011). An analysis of a large body of literature conducted by Hallinger, Heck, and Murphy (2014) focused on the goals of principals to achieve positive results through evaluation. Ultimately, they recommended principals put most of their efforts into non-evaluative activities, such as creating professional communities for teachers to work together, as well as providing on-going feedback and opportunities at high-quality professional development (Hallinger et al., 2014). Despite the differences in results, all of these studies reflect a need for teachers to have support from peers as well as principals, an atmosphere of openness between staff and administration and the opportunity to improve skills through professional development. Improving education for all through teacher evaluations continues to be a highly debated and researched topic; however, some of the research in this area includes a focus on the skill and abilities of the principal as an instructional leader in the school.

\section{Principals' Perceptions}

Principals are most often the person responsible for conducting observations of all teachers on their staff and making important employment recommendations based on these observations. The literature is somewhat limited and ambiguous on the perceptions of the principals as they conduct interviews of teaching applicants and assess the skills of current personnel to make the best decisions and recommendations for the school. The change from school district compliance with state and federal expectations to one of accountability has changed the focus of classroom observations. More and more districts are including student data as part of assessing the effectiveness of classroom teachers; however, principals still play the most important role in the observation process as they 


\section{PRINCIPALS’ PERCEPTIONS}

attempt to identify the highly effective teachers in their classrooms (Loeb, Kalogrides, \& Beteille, 2012).

According to a study conducted by Torff and Sessions (2005), principals perceived pedagogical weaknesses, such as lesson planning and implementation, as well as lack of classroom management skills as the most important reasons teachers were ineffective. Principals perceived weaknesses in content knowledge as one of the least important factors for teacher effectiveness (Torff \& Sessions, 2005). Torff and Sessions repeated this study in 2009 with a specific focus on the perceptions of principals in secondary settings where content knowledge in specific subjects is a required part of most traditional teacher certifications. Here as well, the results indicated principals perceived weaknesses in classroom pedagogical skills such as classroom management as the most important cause of teacher ineffectiveness, followed by weaknesses in lesson planning, with content knowledge weaknesses as the least likely cause of ineffectiveness (Torff \& Sessions, 2009). A more recent study conducted by Nixon et al. (2016) into the reasons for principal non-renewal recommendations identified lack of pedagogical content knowledge as the most common sign of ineffective teaching and cause for nonrenewal. Nixon et al. (2016) included classroom management and lesson planning as key components in pedagogical knowledge and emphasized the necessity of weaving together the subject content knowledge and the pedagogical content knowledge, or ability to teach the content, when identifying highly effective teachers.

This perception by principals disagrees with current research indicating both pedagogical skills and content knowledge are equally important characteristics of a highly effective teacher (Shulman, 1986; Grossman, 1990; Darling-Hammond, 2000; 


\section{PRINCIPALS' PERCEPTIONS}

Darling-Hammond et al., 2005). Along with these skills, other studies include the teacher's ability to make connections with prior knowledge for students, create supports for student learning, and continuously assess student learning, as important characteristics of the most effective teachers (Darling-Hammond, Amrein-Beardsley, Haertel, \& Rothstein, 2012; Darling-Hammond \& Youngs, 2002). This discrepancy in what principals' perceive as important teacher characteristics and what the research says about highly effective teachers could have an impact on how principals hire, assess, and assign teachers.

Literature supports the importance of the power of administration to put the right people in the right positions and remove ineffective teachers as an extremely important factor in successful schools (Loeb, Kalogrides, \& Beteille, 2012). A study conducted by Donaldson (2013), however, revealed principals often feel constrained by teacher contracts, school culture and financial restrictions to hire the best person for the job, move an experienced or tenured teacher to a different position, or remove a teacher who is not able to meet expected standards. School culture and tradition can also make it difficult to assign teachers to teach where they will be the most effective when seniority deems teachers with experience will be assigned more choice classes while new inexperienced teachers are usually assigned to more challenging classes (Donaldson, 2013). Further research supports the concept of barriers or traps for principals in evaluating teachers to best promote effective teaching and support student learning (Cooper et al., 2005). As instructional leaders, principals are responsible for assessing the effectiveness and proper placement of all teachers, however, Cooper, Ehrensal, and Bromme (2005) point out three specific "traps" principals can fall into when attempting 


\section{PRINCIPALS’ PERCEPTIONS}

to conduct these evaluations. They can be trapped by bureaucracy, the semiprofessional characteristics of education, which allows for more autonomous behavior in the workplace, as well as the empowerment and shared decision-making process, which has recently developed in schools, and can undermine the power of the principal (Cooper et al., 2005). This research reveals the current structure of our education system, which is one of traditional hierarchy with promotion based on tenure, can be a barrier to the reforms we know will close the learning gap.

Additional research, however, indicates principals are also highly influenced by their own personal background, philosophies, and experiences, as well as the thoughts of others, such as assistant principals and other teachers during the hiring and observation process which can impact the personnel recommendations they make (McGough, 2003; Ingle, Rutledge, \& Bishop, 2011). At the same time, principals perceive each opening which must be filled as unique and requiring different teacher characteristics depending on the personalities of the teacher team or department this person would be joining (Ingle et al., 2011). Even with these challenges however, research does show principals have the ability to identify teachers based on effectiveness in the classroom (Rivkin, Hanushek, \& Kain, 2005). The expectation of NCLB (2001) and ESSA (2015) legislation is to put a highly effective teacher in every classroom to provide a high quality education for all students and close the learning gap, which is a challenging responsibility of school districts and principals involved in this process.

\section{Summary}

The body of knowledge developed by educational researchers over the last several decades is immense. The research indicates we can close the learning gap even though 


\section{PRINCIPALS' PERCEPTIONS}

there are still differences of opinion on the best method to do so. Throughout the research, however, there is a common thread where many researchers agree a highly effective teacher is an extremely important component in closing the gap and the role of the principal is crucial in identifying highly effective teachers. Research also indicates principals, overall, do have a sense of the characteristics of a highly effective teacher even though this research seems to be somewhat limited especially as it relates to the perceptions of rural high school principals. Digging deeper into the principals' perceptions as they attempt to assess the skills of current teachers, hire new teachers, and place the most effective teachers where they are most needed is an extremely important part of continuing to improve education for all. The responsibilities of principals is ever increasing with the many changes in legislation and increased accountability of school districts, individual schools, principals and teachers to show student growth and improvement in closing the learning gap. The purpose of this research is to clarify the perceptions of the principals as they attempt to put a highly effective teacher in every classroom. 


\section{PRINCIPALS' PERCEPTIONS}

SECTION FOUR:

CONTRIBUTION TO PRACTICE 
PRINCIPALS' PERCEPTIONS

\section{Plan for Dissemination of Practitioner Contribution Type of Document}

A white paper is the best choice for sharing and informing readers on the information gathered in regard to the principals' perceptions of the characteristics of a highly effective teacher. This type of report is usually a concise, easy read and would be appropriate for busy administrators to read in a timely manner and still be able to get the important information needed from the report.

\section{Rationale for this Contribution Type}

A white paper is an easily distributed document, which could reach a wide variety of administrative personnel who are currently involved in the teacher evaluation process.

Who: Principals, Superintendents, Missouri Department of Elementary and Secondary Education Director of Evaluation System, as well as leadership and teacher preparation programs.

When: Anytime during the school year; however, the best time to get this information out to administrators would be during the months of June through August when they are involved in professional development for the coming school year and have more time to read research material.

How: Mail or E-mail will be the most efficient form of delivery.

\section{Outline of Proposed Contents}

Introduction

Problem of Practice

Findings:

$\begin{array}{ll}- & \text { Observations } \\ \text { - } & \text { Interviewing and Hiring } \\ \text { - } & \text { Red Flags of Ineffectiveness }\end{array}$

Discussion

Recommendations

Conclusion

References 
PRINCIPALS' PERCEPTIONS

\section{Rural Missouri High School Principals' Perceptions of Highly Effective Teachers: Does It Align With National Research?}

\section{A White Paper by Marcia Sankey}

\section{Introduction}

How do rural Missouri high school principals identify, hire, and retain highly effective teachers for every classroom? The purpose of this study was to discover the perceptions of rural Missouri high school principals of the characteristics of a highly effective teacher as they assess the skills of current teachers and interview prospective teachers for open positions. Principals are the link between the applicant for the teaching position and the classroom. They play a vital role in who is in the classroom every year and their perceptions are important, as they are the only ones observing and assessing the successes and failures, strengths and weaknesses of all teachers.

\section{Problem of Practice}

An excellent, highly effective teacher is the single most powerful influence on student achievement (Hattie, 2003). Data and research shows that a highly effective teacher in the classroom is one of the best tools for closing the learning gap (Donaldson, 2013; Johnson, 1999; Leithwood, 2010). The problem is do rural Missouri high school principals perceive and identify the same characteristics of highly effective teachers as is indicated by the research. Shulman (1986) as well as Grossman (1990) identified an effective teacher as someone who has both strong content knowledge and the pedagogical skills to teach the content. Along with these skills, other researchers include such characteristics as helping students make prior connections with learning, creating supports for student learning, and continuously assessing student learning as attributes of 


\section{PRINCIPALS' PERCEPTIONS}

an effective teacher (Darling-Hammond, 2000; Darling-Hammond, 2012; DarlingHammond, Amrein-Beardsley, Haertel, \& Rothstein, 2012; Darling-Hammond, Holtzman, Galtin, \& Vazquez Heilig, 2005). Still other researchers identify a highly effective teacher as one who can reach and teach all students and is capable of closing the learning gap identified by the testing data (Holland, 2007; Leithwood, 2010).

With all of these characteristics in mind, however, it is very important to remember that identifying, hiring, and retaining the most highly effective teachers is the responsibility of the principal and this can be a very difficult task to carry out. The rural Missouri high school principal faces increased accountability and expectations for all students to have highly effective teachers and the opportunity of an excellent education.

\section{Findings}

Results of this study indicate rural Missouri high school principals perceive the pedagogical skills of student engagement and relationships as well as classroom management as the most important characteristics of highly effective teachers. The principals followed this focus on pedagogy with emphasis on pedagogical content knowledge, like lesson planning and relevance of lessons, but did not include the subject content knowledge of the teacher as an important factor. Whereas, research indicates a highly effective teacher has strong pedagogical skills to manage a classroom, possesses strong subject content knowledge, and can use pedagogical content knowledge to teach

effectively the content material to all students (Shulman, 1986; Grossman, 1990; Hattie, 2003). When questioned, principals expressed the belief that content knowledge was extremely important to the skill of the teacher in the classroom but was not nearly as important as student engagement, relationship building, and classroom management. 


\section{PRINCIPALS’ PERCEPTIONS}

\section{Characteristics of a Highly Effective Teacher as Observed in the Classroom}

Rural Missouri high school principals perceived the teacher's pedagogical skills of student engagement, relationship building, and classroom management as the most important characteristics of the effective teacher's classroom. When observing current teachers, principal C referred to it as the "the organized chaos of learning". Principal A described it as an elusive "it factor" or as an atmosphere they could feel when stepping into a highly effective teacher's classroom. These statements are perceptions based on the thinking and feeling of the principal when they think about the characteristics of an effective teacher rather than all three parts of effective teaching as is defined by research included in this study. For the principals, these were interwoven characteristics which if present, led to learning and student growth. The principals emphasized that student engagement in a relevant lesson was extremely important and tied it to the foundation of a well-managed classroom. These principals perceived a well-managed classroom and an atmosphere of mutual respect as the key to engaging students in the learning and the most important characteristic of effective teaching. Six of the eight principals specifically identified student engagement as one of the first things they looked for when entering a classroom. Principal D openly stated that the first thing she looked for when going into a classroom is engagement, "are the students engaged in the class." She went on to say she "loved John Hattie" and felt relationships were the most important factor in the classroom, which she continued to weave together with engagement throughout the interview. Principal B stated, "[Effective teachers] have to be able to engage the students. Need to find those people who just inspire but that also means they make connections to relevance." According to principal C, "An effective teacher could mean a 


\section{PRINCIPALS' PERCEPTIONS}

lot of different things and your style and his style could be totally different and the rooms totally different and both dynamite. It's really tough, somewhere you have to be making a connection with your students... I think ... somewhere along the line you have to have a level of student engagement in your classroom." "The most effective teacher exhibits enthusiasm for students and the content. Students are engaged in the content and teachers are communicating the content," according to Principal H, which indicates more of an awareness of the pedagogical content knowledge of the teacher by this principal.

Two principals included the engagement of the teacher in their description of effective teaching. Principal F said, "The first thing I look for is, are they [the teacher] up actively teaching. The teacher is up actively teaching and engaged with the class. Student engagement is huge." Principal F also said, "I need my teachers $100 \%$ engaged in there, you know, not at their desk or not doing something on the side that doesn't pertain to the group."

Three principals put a heavy emphasis on the relationship side of teacher classroom management skills. Principal A stated that one of the most important components was “The relationship piece. I'm talking about a relationship where that teacher may not be the students' favorite teacher but they know that that teacher is going to make them work hard, have high expectations, hold them accountable and be

consistent. Work their tails off but care about them." According to Principal C, "At some level there has to be that connection with students. Without that you probably aren't going to be effective." "Their relationships with kids and their relationships with coworkers when they are not in the instructional classroom. You know, our most effective teachers are the ones that are the most visible in the hallways between classes, and talk 


\section{PRINCIPALS’ PERCEPTIONS}

with students and interact with students in an informal manner, you know in a

professional way. I think they are the ones who are most likely to have a conversation in the teacher's lounge or in the work-room, you know, share information, teachers talking about student issues," stated Principal E.

At least two principals specifically identified communication skills as key to relationships and effective teaching. "Ability to communicate with students, confident in their subject matter, able to build relationships while still maintaining, uh, a pretty organized classroom, you know. Organized probably isn't the word, but well, wellmanaged classroom where students feel safe," according to Principal F. According to Principal H, "Connections include communication skills and a student-centered focus. They are great communicators with students and staff and model expectations in the classroom. The most important characteristic is that they teach students first over anything else." For these principals the emphasis seemed to be on the pedagogical foundation skills of relationships, engagement, and communication.

Other more basic procedural types of pedagogical skill emphasized during the interviews by most of the principals as characteristics of effective teachers included good classroom management skills and strong lesson planning and delivery. Two principals specifically referred to the Madeline Hunter model of teaching as an effective process for good planning, preparation, and delivery of the content. Principal A specifically said, "Planning and preparation clearly evident. Is there intentional planning, you know the old classic Madeline Hunter model. You know, do you tell them what you want them to know by the end of the period? I expect my teachers to have, you know, proper classroom management, well-planned instructional activities, and teach bell to bell." "A 


\section{PRINCIPALS’ PERCEPTIONS}

well-managed classroom is where kids feel safe. For me, that's what's wrong with an out of control classroom is that two or three or four are disruptive and the other sixteen don't feel very safe," stated Principal F. "I'm a firm believer in procedure. If you can't manage the room, then you can't even manage a lesson," Principal B. "I love to hear Madeline Hunter, ... I like to hear, do they think about a beginning, a middle, and end of the lesson," Principal D. Other principals described a similar structure, for example Principal A states, "You should be able to see some direction, there's a method to their madness, umm, you know, they know where they are going, the kids seem to understand what's going on."

There is an obvious focus on the pedagogical skills of relationships and student engagement in the comments made by these principals. At the same time, many of the principals' comments also identify their own experiences and learning as influences on their perceptions. The references to Madeline Hunter whose research guided teacher preparation programs for decades, when referring to planning lessons and teaching bell to bell as a part of effective teaching reflects some of their professional training. Their reference to the more recent work of John Hattie when discussing relationships, as part of how they judge the effectiveness of the classroom teacher identifies the influence of their own current learning and possible professional development on their view of effective teaching. This indicates principals may be aware of all of the characteristics of an effective teacher but possibly influenced by training based on work by researchers like John Hattie (2003) and others, when conducting observations and interviewing prospective teachers. 


\section{PRINCIPALS’ PERCEPTIONS}

When questioned about the importance of content knowledge seven of the eight principals indicated subject content knowledge was extremely important in giving the teacher the grounding or foundation needed to be effective teachers and impart content knowledge. Two principals actually said they would put content knowledge first but were quick to add that content was useless without the pedagogical skills to deliver content in the classroom. Principal B stated, "Content has to be first and then their personalities and how it connects comes in behind it. How they motivate and engage kids - but they gotta know their stuff." On the other hand, however, Principal A believes, "You do have to know your content but none of that is going to mean anything if you don't have a lesson well planned with varying levels of rigor and examples." Six of the eight principals, however, placed content knowledge of the teacher as a close second or possibly third if forced to rank as a skill needed to be an effective teacher. Two principals even commented that they believed someone who had the pedagogical knowledge of classroom management and planning could increase their content knowledge more efficiently along the way, than someone who might need to improve their pedagogical skills. Three principals stated that in the end, pedagogical skills outweighed content knowledge in an effective teacher's classroom. "Content knowledge, it's important, but it's not number one. I mean the ability to run a classroom, the ability to collaborate with your peers, interact with, engage your students is most important," according to Principal C. He went on to add, however, "if you don't know your subject matter, you're gonna be exposed at some point. On the other hand if you don't like kids and you can't work with students you're gonna also get exposed. So, you know, they probably walk hand in hand. They both have to be in place but if I had to 


\section{PRINCIPALS’ PERCEPTIONS}

lean one way or the other, I would lean toward that person, the engagement piece with the students, the connection has to be there." Principal E states, "I would say that content knowledge is, you know, right there with critical planning. I think that being able to engage kids ultimately is a baseline thing, I mean you can learn content knowledge." Principal D had a different view of content by saying "It's important they have a passion for their content but kids must be most important to them. Kids are their focus." Finally, Principal G strongly stated, “I definitely don't think it's [content] number one because there's some very bright people that know their stuff who can't teach a lick."

The results of this study indicate rural Missouri principals believe content knowledge is extremely important in the effective teacher's classroom but it is not as important as strong pedagogical knowledge and pedagogical content knowledge. Almost all of the descriptors of effective teaching used by these principals fell into the pedagogical category of classroom management or pedagogical content knowledge category, which includes the ability to engage students in a well-planned lesson and the reciprocal relationship between teacher and student. Even discussions of teacher subject content knowledge came back to engagement, as well as teacher enthusiasm for the content, and not the actual content itself.

These comments and perceptions of the rural Missouri high school principals seem to reflect a common use of terminology such as engagement, connections/relationships, and learning environment with a heavy focus on pedagogical content knowledge and skill. According to principals, more modern observation practices include shorter more frequent walk-through observations rather than the more traditional longer observations of the PBTE. Most reported the increased frequency was 


\section{PRINCIPALS’ PERCEPTIONS}

a better method of seeing teachers in action and stimulated more productive, less formal conversations about what was going on in the classroom. Two principals, however, described a process of both long and short observations due to a lack of understanding about the process by teachers and the principals lack of time to complete as many visits as they wanted. Surprisingly, however, none of the principals described doing exactly the same thing as another principal in this study. Each district had a slightly different method for conducting teacher observations.

I was surprised by the heavy focus on student engagement and the reliance on how the principal "feels", or their instincts, when in the company of an "effective" teacher. Some of these same ideas and attitudes carried over into the hiring process as well. Similar to the observation process, when interviewing teachers, principals focused more on the pedagogical skills of classroom management and lesson planning, as well as personality traits such as honest, humble, and caring, and focused much less on specific subject content knowledge.

\section{Characteristics of a Highly Effective Teacher as Identified During an Interview}

During the interview process, rural Missouri high school principals identified the ability to manage a classroom, which includes lesson planning skills, and the ability to build relationships, which includes engaging students as the two most important characteristics of an effective teacher. This is almost exactly the same characteristics as were identified for highly effective teachers already in the classroom. A third characteristic or category of characteristics of an effective teacher emphasized by principals, however, was personality traits such as enthusiastic, honest, and caring. Rural 


\section{PRINCIPALS' PERCEPTIONS}

Missouri high school principals did not specifically focus on these traits or characteristics when talking about teachers already in the classroom.

All principals in this study described a similar and yet slightly different process for choosing and interviewing teacher candidates. All were in charge of vetting the applications, choosing the candidates, and conducting the interviews. Three of the eight

did specifically identify including the assistant principal and possibly a content teacher as an interview committee if time and availability allowed. Before they can focus on these characteristics, the principals involved in this study identified narrowing the applicant pool as the first step in the interviewing and hiring process, then choosing applicants to interview. For smaller, more rural Missouri high schools, however, that meant they might have to interview all of the three or four candidates who applied in hopes of finding a strong effective teacher in the mix. Occasionally, the challenge is even greater for the most remote districts, when no one applies, which can occur in the areas of math and science especially. When districts do have multiple applications, however, the quality of the completed application itself can determine the next step. All of the principals said they would automatically cut an applicant who had submitted a sloppy or carelessly completed application, which included typos and poor grammar. They questioned the work ethic and caring of the applicant toward the job if they were so careless with their first impression. The principals would also avoid any applicant who seemed to have a history of job-hopping, a history of only a year at a school, for fear they would be getting an extremely weak, unreliable teacher and would only have to replace that person in a year. Good grades were also important, especially in their content areas and methods classes when deciding which applicants to interview. Grades in student 


\section{PRINCIPALS’ PERCEPTIONS}

teaching, however, were only important if the candidate had received a grade below a B. Three principals actually expressed some doubt that there was any real meaning in either an $\mathrm{A}$ or a B in student teaching. Receiving a $\mathrm{C}$ or less, however, was a red flag that something did not go well during student teaching, indicated to them that this candidate probably has weak PK and PCK, and would not do well as a teacher in the classroom.

Once the principals have chosen applicants to interview, most principals were interested in the pedagogical skills applicants have to engage students and manage a classroom. Principal G states, "Good teachers, I think, just do the whole big picture. You know, the management, the planning, the curriculum, it's all kind of coming together to form you as a teacher." Principal A is looking for "The type of person who can come in and command a classroom and be professional and be respectful." At the same time, he included personality traits he felt were important for the person to fit into his building, “. . . has a personality, can build relationships, are humble, straight forward. Nothing aggravates me more, especially with these new ones coming in, and trying to use all of these educational acronyms and playing that education bingo. I want someone who is just real, humble." In an attempt to assess pedagogical skill and true personality of the applicant, two of the eight schools participating in this study have applicants schedule a time to teach part of a lesson as an important part of the interview process. These two districts use this activity to identify the applicant's classroom management skills, and pedagogical content skills, as well as address the concern the new hire "fit" the current culture of the school, relate to other staff, and have a "positive, caring personality in the classroom," according to Principal C. All of the principals interviewed indicated the need for an applicant to "fit" into the culture of the team or building as an important 


\section{PRINCIPALS’ PERCEPTIONS}

consideration. Principal B even indicated his school board expected him to hire more local people or people from areas nearby in order to minimize turnover. He struggled with this in hard-to-fill jobs, especially band and choir director positions or higher-level math and science positions.

During the interview of the principals, when the focus of our conversation turned to the content knowledge of the applicant, like the results of current classroom observations, principals were more interested in the excitement the candidate showed about teaching the material and a general interest they had in the content area rather than the level of content knowledge itself. Principals actually expressed concern about teachers who were brilliant in the content but did not possess pedagogical skills to manage a classroom, plan an engaging lesson, or impart the knowledge in a manner that was understandable by the students. They commented that some of the alternative methods of certifying teachers in Missouri today were producing teachers who do not have enough general teaching skills or teaching skills in the content area that they received an additional certification in to teach multiple topics. Principals seemed to agree that, for example, a teacher who holds a traditional Missouri certification to teach high school science might not have the skills to teach high school English just by getting the additional content certification in that area. They agreed that there is a great need to increase the number and quality of teachers in our schools today; however, they also emphasized that having time in the content area classroom before certification was vital to the effectiveness and overall success of the teacher in the classroom. Three of the principals specifically indicated they were more likely to hire someone with a traditional 


\section{PRINCIPALS’ PERCEPTIONS}

degree and teaching certificate over an equal candidate who had gone an alternative route into teaching.

See Table 2 for a detailed list of the principals' perceptions of the characteristics

of an effective teacher as principals conduct interviews to fill open teaching positions.

Table 2. Characteristics of an Effective Teacher Applicant

\begin{tabular}{|c|c|}
\hline Interviews & What are you looking for in an effective teacher applicant? \\
\hline $\begin{array}{l}\text { Planning, } \\
\text { Preparation, } \\
\text { and } \\
\text { Management }\end{array}$ & $\begin{array}{l}\text { Not afraid to get their hands dirty. } \\
\text { Lesson planning skills - Instructional strategies. } \\
\text { Describe best lesson and worst lesson - are they reflective? } \\
\text { Differentiated classroom ideas - meet the needs of all kids. } \\
\text { How do they evaluate student growth? } \\
\text { Don't blame student failure or lack of success on others, kids, etc. } \\
\text { They understand how the whole picture - Management, planning, } \\
\text { curriculum and it comes together to form you the teacher. } \\
\text { Classroom management ability without continuous support - Low } \\
\text { maintenance. } \\
\text { Classroom management - What is their first response to a student cheating } \\
\text { or crying? }\end{array}$ \\
\hline $\begin{array}{l}\text { Student } \\
\text { Engagement, } \\
\text { Relationships, } \\
\text { and } \\
\text { communication } \\
\text { skills }\end{array}$ & $\begin{array}{l}\text { Can they describe their classroom? What are they doing? What are the } \\
\text { kids doing? } \\
\text { Emphasis on communication with kids. } \\
\text { Must fit the school culture - shared leadership - Must get along. } \\
\text { Do they talk about what is best for students? } \\
\text { How well do they articulate thoughts? } \\
\text { Do they put kids first? } \\
\text { Do they make a good connection with those who interview them? } \\
\text { Do they fit in with the culture and expectations of team or department? } \\
\text { Able to deal with parents effectively? } \\
\text { Require candidate to teach a lesson - Can they build a rapport with the } \\
\text { students and conduct a lesson. } \\
\text { What are their thoughts on contact with parents? } \\
\text { "Show me that you can relate what you know to real life in your lessons." } \\
\text { Good teachers I think just do the whole big picture. You know, the } \\
\text { management, the planning, the curriculum, it's all kind of coming together } \\
\text { to form you as a teacher. }\end{array}$ \\
\hline Personality & $\begin{array}{l}\text { Personality - Looking for a "kid magnet" - Which one of those folks do you } \\
\text { feel like kids are going to respond to? } \\
\text { Be themselves - Honesty. } \\
\text { Humble and straight forward. } \\
\text { Steady. } \\
\text { Seem to care about kids. } \\
\text { Genuine. }\end{array}$ \\
\hline
\end{tabular}




\begin{tabular}{|c|c|}
\hline & $\begin{array}{l}\text { Seem interested in the job. Why do they want to teach here? } \\
\text { Look for the best person for that specific room. } \\
\text { Are they a fit for the team (PLC team)? } \\
\text { Moldable. } \\
\text { Personality to relate to kids and parents and teachers. } \\
\text { How they come across - pleasant, positive, are they willing to share. } \\
\text { Personality and good content knowledge make a good teacher. } \\
\text { A little bit quirky - teach a little differently. } \\
\text { Sees the big picture. } \\
\text { Can list their strengths AND their weaknesses. } \\
\text { Being honest with who you are. } \\
\text { Transparency. } \\
\text { Enthusiastic. } \\
\text { Personality, professionalism, real, relationship builder. } \\
\text { Fit it with the school culture. }\end{array}$ \\
\hline Content & $\begin{array}{l}\text { Excitement about content. } \\
\text { Ask content questions - looking for passion. } \\
\text { Personality and good content knowledge make a good teacher. } \\
\text { They are not only enthusiastic but they have good knowledge. }\end{array}$ \\
\hline Other Skills & $\begin{array}{l}\text { Diverse skills - more than teaching. Need people to fill multiple roles. } \\
\text { Have something they can and will do with clubs or sports after school. } \\
\text { How do they measure their own growth? Are they reflective learner? }\end{array}$ \\
\hline
\end{tabular}

As a part of our conversations about the characteristics of an effective teacher, principals also shared their thoughts on the "red flags" they felt were obvious signs of ineffective teachers. Here to, the emphasis is on pedagogical knowledge and pedagogical content knowledge and does not focus on the subject content knowledge of the teacher which supports the results of the studies conducted by Torff and Sessions $(2005,2009)$ as well as the study conducted by Nixon, Packard, and Dam (2016).

\section{Red Flags of Ineffectiveness}

"Unorganized, unprofessional, and lazy" were the most common descriptors used when asked to describe an ineffective teacher. Most commented that a messy chaotic room did not necessarily indicate ineffectiveness but a disengaged, unprepared teacher with a chaotic room was definitely an ineffective teacher. Principals felt this indicated the teacher did not plan well for the lesson and did not have a way to engage students in 


\section{PRINCIPALS' PERCEPTIONS}

the learning. Below is a list of the characteristics of an ineffective teacher, as identified by these eight principals. Some of these statements, such as "Young teachers unwilling to do more than teach" (Principal B), may reflect the unique needs of a rural Missouri high school for teachers to have more than one responsibility in the school, such as teaching and coaching, in order to provide all of the opportunities for students expected by the community.

See Table 3 for a list of characteristics principals perceive indicate an ineffective teacher.

Table 3. - "Red Flags" - Characteristics of an Ineffective Teacher

\begin{tabular}{|c|c|}
\hline Group & Red Flags or Characteristics of an Ineffective Teacher \\
\hline $\begin{array}{l}\text { Teachers in the } \\
\text { classroom }\end{array}$ & $\begin{array}{l}\text { Not very organized } \\
\text { Not very professional } \\
\text { Lazy - don't plan } \\
\text { Teachers who are rushing in at the last minute or always prepping or } \\
\text { grading between classes. } \\
\text { Constantly working late - could be a sign of stress or overload } \\
\text { Seen over time - sitting behind the desk too much, typing on the } \\
\text { computer, Not interacting with students, Not walking around helping } \\
\text { them. This is a lack of preparation - Not prepared - Working on their } \\
\text { stuff. } \\
\text { Student work day - No teacher interaction - Teacher wastes time causes } \\
\text { kids to misbehave. } \\
\text { Teachers who are not student centered. Entitled attitude, Not a team } \\
\text { player. } \\
\text { Selfishness - school or kids owe me something attitude. } \\
\text { Gut feeling when you walk into the classroom that things just ratcheted up } \\
\text { a notch because you just walked in. Kids are being snapped out of their } \\
\text { slumber. } \\
\text { Sometimes technology is a crutch or a time filler. } \\
\text { Frustrated or growly teacher - feels they can't get their point across or } \\
\text { they can't get kids to score well or even do their work - unpleasant } \\
\text { atmosphere - teacher who is sick of education. } \\
\text { Less effective teachers see teaching in separate parts - Management, } \\
\text { planning, curriculum as separate things. } \\
\text { Tolerate or ignore disruptive behaviors that distract learners } \\
\text { Too little communication } \\
\text { Too little follow through with expectations }\end{array}$ \\
\hline $\begin{array}{l}\text { Teacher } \\
\text { Applicants }\end{array}$ & $\begin{array}{l}\text { Alternative certification - no methods classes } \\
\text { Poor grammar on applications } \\
\text { Misspelled words }\end{array}$ \\
\hline
\end{tabular}




\begin{tabular}{|l|l|}
\hline Resume is junk - poorly written with bad grammar \\
Copy and paste errors on application or resume - Not paying attention or \\
just don't care. \\
Young teachers unwilling to do more than teach. \\
Gut response - they aren't exciting to me. \\
They are not dynamic and I wouldn't want kids to spend time with them. \\
$\begin{array}{l}\text { Why has someone been in } 12 \text { schools in } 13 \text { years or why are they leaving } \\
\text { after just one year - were they non-renewed? } \\
\text { Teacher applicants with praxis certification and has not majored or } \\
\text { student taught in those subject areas. } \\
\text { Low grades (C-F) in subject matter. }\end{array}$ \\
\hline
\end{tabular}

\section{Discussion}

The results of this study do not seem to coincide with the research included in this study. Results indicate that principals put a heavy emphasis on pedagogical skills such as classroom management and student engagement as the most important indicator of teacher effectiveness or ineffectiveness as identified by Torff and Sessions (2005 \& 2009) as well as Nixon, Packard, and Dam (2016). This study identifies a difference in what research says an effective teacher is and what principals perceive as an effective teacher. Both research and principals identify strong pedagogical knowledge and pedagogical content knowledge, such as lesson planning, as extremely important for effective teaching. The research included in this study, however, places an equal emphasis on pedagogical knowledge, pedagogical content knowledge and the subject content knowledge of a teacher to indicate effectiveness, (Shulman, 1986; Grossman, 1990; Darling-Hammond, 2000; Darling-Hammond et al., 2005). In talking to rural Missouri high school principals about what they perceive as the most effective teachers, their first comments tended to reflect the pedagogical knowledge and training of teachers, while they all seem to believe that content skill is very important, it did not appear in their comments about an effective teacher without direct questioning. Research indicates 


\section{PRINCIPALS' PERCEPTIONS}

that pedagogical skill and pedagogical content knowledge, as well as strong content knowledge together are equally important for teachers to be effective (DarlingHammond, 2000; Hattie, 2003; Shulman, 1986). Effective teachers must be able to manage a classroom, understand and know well the content they teach, the curriculum attached to that content, and be able to plan effective, engaging lessons to teach the content in multiple ways for all student to learn (Shulman, 1986; Grossman, 1990; Darling-Hammond, 2000; Darling-Hammond et al., 2005; Hattie, 2003).

When asked about identifying the content strength of the teacher, principals did feel this was a challenge; however, most felt that they could see evidence of content knowledge strength in the quality of the lesson planning and the teacher/student interaction throughout the lesson. These findings indicate principals may be paying attention to content through the pedagogical lens of lesson planning but in reality, content knowledge does not seem to receive the same focus as the pedagogical content skills of content delivery. Principals emphasized the fact they believed content knowledge was very important and made the teacher's job of engaging students and teaching a lesson much easier if they had confidence in the content. Three specifically noted the increased reliance on Professional Learning Communities (PLC's) in their schools, which allows subject content teams to collaborate and support each other in both content subject knowledge and pedagogical content knowledge. Not all schools in the study, however, have the resources to provide the additional time for teachers to work in PLC teams or a large enough staff to create teams.

Principals also seem to have similar perceptions of prospective teachers when conducting interviews. Two specifically expressed concern about the alternative methods 


\section{PRINCIPALS’ PERCEPTIONS}

of teacher certification, which may allow someone to teach a subject without pedagogical training or teaching experience in the content area. They also placed heavy emphasis on classroom management, lesson planning skills, and concerns of fit for the culture of the school and community when planning to hire a prospective teacher. Many comments made about the hiring of someone for an open position when talking about fit seemed to be about the personality of the applicant rather than skill. The human resource frame and social capital theory put a great deal of emphasis on the "fit" of individuals in an organization and in rural Missouri high schools finding this "fit" is the responsibility of the principal (Allan \& Catts, 2014; Bolman \& Deal, 2008; Putnam, 1995). Seven of eight principals spoke of their schools and teachers in positive, collegial fashion where

the teachers were caring and responsive to principal leadership and guidance and worked well together. This could indicate that principals have been able to find the correct "fit" for the school but does not necessarily indicate effectiveness of teachers. School boards and community voters determine the hiring guidelines established for the school district and these usually strongly reflect the beliefs of the community at large. Rural Missouri high schools are small communities within the larger community they serve and the community expects they will represent their beliefs and values as well as provide an excellent education to their children.

\section{Recommendations}

This study indicates principals do understand and know the characteristics of effective teachers but are not necessarily focusing on the subject content knowledge of the teacher when observing and hiring teachers. An effective teacher, according to research has strong pedagogical knowledge, pedagogical content knowledge, and subject 


\section{PRINCIPALS’ PERCEPTIONS}

content knowledge (Darling-Hammond et al., 2012; Hattie, 2003; Shulman, 1986). The researcher recommends the following steps to ensure a highly effective teacher is in every classroom.

- Where and when possible, create teacher teams to discuss the specific curriculum content to be taught for each unit of teaching. Create common lessons, as well as formative and summative assessments as a team to increase the content knowledge and provide content support for those who struggle. Collaboration among teachers could also provide novice teachers with more support to become highly effective teachers over time.

- Review the professional development provided at the state and local level to provide content specific professional development opportunities for teachers throughout the school year.

- When possible, the principal could collaborate with a content area teacher, especially the department chair as the teacher leader, to conduct walk-through observations to provide feedback on both pedagogy and content to the observed teacher. Since the principal probably is not a content expert in all areas he or she is expected to observe and assess, it is vital that someone with more knowledge assist in giving constructive subject content feedback to teachers. These should be non-evaluative, feedback only opportunities.

- Assess hiring practices and provide guidance to school board members on the characteristics of highly effective teachers, to better inform their hiring policy decisions. School board members need to know what makes up an effective 


\section{PRINCIPALS' PERCEPTIONS}

teacher and should use these characteristics from research to review hiring expectations and guidelines in place.

\section{Conclusion}

Principals work hard to identify highly effective teachers as they observe classroom teachers and conduct interviews to hire prospective teachers. The challenge for rural Missouri high school principals is to ensure they are identifying truly effective teachers who have strong pedagogical knowledge, pedagogical content knowledge, as well as strength in subject content knowledge. Rural Missouri high school principals are the most important link between the highly effective teacher and placement in a classroom where students can have access to an excellent education. 


\section{PRINCIPALS’ PERCEPTIONS}

\section{References}

Allan, J., \& Catts, R. (2014). Schools, social capital and space. Cambridge Journal of Education, 44(2), 217-228. http://dx.doi.org/10.1080/0305764X.2013.863829

Bolman, L., \& Deal, T. (2008). Reframing organizations: Artistry, choice, and leadership. San Francisco, CA: Jossey-Bass.

Darling-Hammond, L. (2000). Teacher quality and student achievement. Education Policy Analysis Archives, 8(1), 1-44. doi:http://dx.doi.org/10.14507/epaa.v8n1.2000.

Darling-Hammond, L (2012). The right start: Creating a strong foundation for the teaching career. The Phi Delta Kappan, 94(3), 8-13.

Darling-Hammond, L., Amrein-Beardsley, A., Haertel, E., \& Rothstein, J. (2012). Evaluating teacher evaluation. The Phi Delta Kappan, 93(6), 8-15.

Darling-Hammond, L., Holtzman, D. J., Gatlin, S. J., \& Vazquez Heilig, J. (2005). Does teacher preparation matter? Evidence about teacher certification, teach for America, and teacher effectiveness. Education Policy Analysis Archives, 15, 151.

Donaldson, M. (2013). Principals' approaches to cultivating teacher effectiveness: Constraints and opportunities in hiring, assigning, evaluating, and developing teachers. Educational Administration Quarterly, 49(5), 838-882. doi:10.1177/0013161X13485961.

Grossman, P. (1990). The making of a teacher: Teacher knowledge and teacher education. New York, NY: Teachers College Press.

Hattie, J.A. (2003, October). Teachers make a difference: What is the research 


\section{PRINCIPALS' PERCEPTIONS}

evidence? Paper presented at the Building Teacher Quality: What does the research tell us? ACER Research Conference, Melbourne, Australia. Retrieved from http://research.acer.edu.au/research_conference_2003/4/

Holland, H. (2007). Can educators close the achievement gap? An interview with Richard Rothstein and Kati Haycock. National Staff Development Council, 28(1), 54-62.

Johnson, L. (1999). The learning gap: Highlighting teachers' competency. Nieman Reports, Spring, 40-42.

Leithwood, K. (2010). Characteristics of school districts that are exceptionally effective in closing the achievement gap. Leadership and Policy in Schools, 9, 245-291. doi:10.1080/15700761003731500.

Nixon, A., Packard, A., \& Dam, M. (2016). Teacher contract non-renewal: What matters to principals? International Journal of Educational Leadership Preparation, 11(1).

Putnam, R. (1995). Tuning In, Tuning Out: The Strange Disappearance of Social Capital in America. Political Science and Politics, 28(4), 664-683.

Shulman, L. S. (1986). Those who understand: Knowledge growth in teaching. Educational Researcher, 15(2), 4-14.

Torff, B., \& Sessions, D. N. (2005). Principals' perceptions of the causes of teacher ineffectiveness. Journal of Educational Psychology, 97(4), 530-537.

Torff, B., \& Sessions, D. N. (2009). Principals' perceptions of the causes of teacher ineffectiveness in different secondary subjects. Teacher Education Quarterly, $36(4), 127-148$. 


\section{PRINCIPALS' PERCEPTIONS}

SECTION FIVE:

CONTRIBUTION TO SCHOLARSHIP 


\section{PRINCIPALS’ PERCEPTIONS}

\section{Target Journal and Rationale for this Target}

The purpose of this study was to put a focus on the perceptions of principals of the characteristics of highly effective teachers. High school principals are responsible for hiring and observing teachers to ensure the placement of a highly effective teacher in every classroom. Understanding the perceptions of the principals as they conduct these observations and interviews could bring to light any discrepancies, which might exist, between what the literature describes as a highly effective teacher and the perceptions of the principals involved in this study.

This chapter presents the findings of this study in a scholarly format, which will be presented for publication as a journal article in the American Educational Research Journal, which is known as the "flagship journal" for the American Educational Research Association. This journal publishes a wide variety of education related articles in many subject areas, disciplines, and across all levels of education. Many of the articles supporting the research for this study were published by this journal and as such, it is a logical choice for potential publication of this article. Due to its' emphasis on rural principals, this article could also be presented for publication to education leadership journals such as Educational Administration Quarterly or Journal of Research on Leadership Education. 
PRINCIPALS' PERCEPTIONS

\title{
Rural Missouri High School Principals' Perceptions of Highly Effective Teachers: Does It Align With National Research?
}

\begin{abstract}
The purpose of this case study was to discover what rural Missouri high school principals perceive as the characteristics of highly effective teachers to compare to the national research on highly effective teachers. High school principals carry a great deal of responsibility for identifying and placing highly effective teachers in all classrooms and it is important to know if they are truly looking at the same characteristics as is identified in the extant literature. For the purpose of this study, the definition of a highly effective teacher is someone who has strong pedagogical knowledge, pedagogical content knowledge, and subject content knowledge to reach and teach all students.

The design of this study was as a qualitative case study of eight rural Missouri high schools within a forty-mile radius. The average $9-12^{\text {th }}$ grade student-body population of the schools was 365 , with an average of $98 \%$ of the student body population identified as Caucasian. Eight rural Missouri high school principals participated in semi-structured interviews to identify their perceptions of the characteristics of highly effective teachers.

The results of this study identify that rural Missouri high school principals focus on pedagogical skills, like classroom management and relationships, as well as pedagogical content skills, like lesson planning and student engagement, to identify highly effective teachers. There is little if any perception of teacher subject content knowledge by the principals as they observe current teachers and interview prospective
\end{abstract}




\section{PRINCIPALS' PERCEPTIONS}

teachers to hire. This oversight could be detrimental to identifying and placing highly effective teachers in every classroom.

\section{Introduction}

How do principals identify, hire and retain highly effective teachers for every

classroom? The purpose of this study was to discover the perceptions of rural Missouri high school principals of the characteristics of a highly effective teacher as they conduct observations of all current teachers and conduct interviews of prospective teachers for open positions. Principals are the link between the applicant for the teaching position and the classroom. They play a vital role in who is in the classroom every year and their perceptions are important, as they are the only ones observing the successes and failures, strengths and weaknesses of all teachers.

\section{Review of the Literature}

\section{Reform Efforts, Teacher Quality, and Learning Gap}

The focus on effective teachers today hinges upon the goal of districts to improve education for all. The continued learning gap is of major concern as our nation becomes more and more diverse and the students from diverse, non-white, or lower socioeconomic backgrounds struggle to achieve success in our nation's schools (Holland, 2007). There continues to be a debate, however, over the causes of the learning gap. In 1964, Congress commissioned a study to determine the actual need for funding to improve equality of education for disadvantaged students. The released results of this study, known as the Coleman Report, placed the main cause of inequality in education on the background and family life of the students and minimized the effect of funding and school setting on the outcome for all students (Austin, 1979; Rojas-LeBouef \& Slate, 


\section{PRINCIPALS’ PERCEPTIONS}

2011). This study did support the idea that education for all was extremely important; however, it minimized the effect of schools and teachers on the differences in the results of education for students from minority or low socio-economic situations (Austin, 1979; Rojas-LeBouef \& Slate, 2011). This report has had tremendous impact on attitudes toward education reforms over the years, even though, not all researchers supported the results or methods of this study as valid. Gamoran and Long (2006), identified many researchers who disagreed with Coleman and pointed to much larger differences within schools than between schools which did account for some of the gap in learning.

Continued research by those who criticized the Coleman Report resulted in data to support other causes for the learning gap. Research by Klitgaard and Hall in 1973 focused on the small number of schools that were successfully closing the learning gap and the results of their study revealed that there was no one characteristic but a combination of factors that made these schools successful where other were not (as cited in Austin, 1979, pp. 11-12). Klitgaard and Hall created a list of factors for successful schools (as cited in Austin, 1979, p.12). These factors included, but are not limited to, such traits as strong participatory principal leadership, experienced principals, and teachers with appropriate education for their positions, as well as strong parent-teacher relationships and higher teacher expectations for all students to graduate and go on to college (as cited in Austin, 1979, p. 12). Additionally, Smith and Tucker described schools with the most consistent impact on closing the learning gap as having strong principals, creative, collaborative teachers who believe in the success of all students, and supportive parents (as cited in Austin, 1979, p. 14). In a more recent study Noguera (2007) summarized the key characteristics and strategies of schools successfully helping 


\section{PRINCIPALS’ PERCEPTIONS}

all students learn as ones committed to engaging parents as partners in education, as well as having strong instructional leadership with curriculum supported by well-trained teachers, and reflective practices on interventions. Leithwood (2010) conducted an analysis of thirty-one scholarly research articles to gather information about the characteristics of school districts, which have been successful in closing the learning gap. According to his analysis of the research, some of the most important characteristics include a district-wide focus on student achievement, which includes the concepts of "closing the gap" as well as "raising the bar" (Leithwood, 2010). Other key characteristics include the development of student performance standards with district wide aligned curriculum, and effective use of data as evidence to plan and organize learning as well as a means of accountability for the district, and district-wide, highly valuable professional development for both teachers and principals (Leithwood, 2010). This research puts a great deal of emphasis on district cohesiveness, with strong principal leadership, and well-trained highly effective teachers as necessary components in closing the learning gap (Leithwood, 2010).

There is still debate, however, about the specific causes and solutions to dealing with the learning gap. An analysis of the data in the research literature conducted by Jencks and Phillips (1998) summarized a body of literature where family background, socioeconomic status, and school factors such as teacher quality were consistently used as the most common predictors of the learning gap. In an interview Richard Rothstein, a research associate at the Economic Policy Institute, contended that schools cannot solve the learning gap issue until other social problems like poverty, sub-standard housing, and health-care issues of students are also addressed by society (Holland, 2007). This 


\section{PRINCIPALS’ PERCEPTIONS}

continues to echo the results of the 1966 Coleman Report and illustrates the division and therefore the difficulties that exist in the movement to reform education and provide highly effective teachers for all students.

\section{Teacher Evaluations and Highly Effective Teachers}

Even though this study will not focus on the evaluation process, it is extremely important to include this research as part of the goal of improving education for all. There is a large body of research available on teacher supervision and evaluation as a means for improving instruction. In the early 1980's, Congress commissioned a study of the status of American schools and in 1983, the government released A Nation at Risk Report which revealed serious weaknesses in the American education system and rekindled public demand for an overhaul of this system. Researchers and educational leaders increased efforts to improve instruction through better teacher evaluation systems. Research conducted and works published by Lewis (1982), McLaughlin and Pfeifer (1988), as well as Gitlin and Smyth (1989), all sought to provide educational leaders with systematic guidance to evaluate teachers in a productive, structured manner which would provide feedback to the teacher and improve activities in the classroom. This research laid the groundwork for the performance based teacher evaluation process that has been the basis of teacher evaluations for many years. Darling-Hammond, Wise, and Pease (1983), however, pointed out for teacher evaluations to be a useful tool to improving education the process needed to have a balance of both standardized performance expectations as well as a teacher-specific approach. At the same time, Shulman (1986) became concerned with what he saw as a decrease in the interest in the content knowledge of the teacher in teacher evaluations. His work focused on the importance of 


\section{PRINCIPALS’ PERCEPTIONS}

both the pedagogical skill of the teacher as well as strength in pedagogical content knowledge and curricular content knowledge (Shulman, 1986). According to Shulman (1986), content knowledge is what the teacher knows, pedagogical content knowledge is the ability to teach content to others in multiple ways, and curricular knowledge includes the ability to tie the content to other content both vertically within a discipline and horizontally between different disciplines. Grossman (1990) also identified through research that teachers with both the strong content knowledge and training in pedagogical skills to teach the content were much more effective in the classroom.

Work by Millman and Darling-Hammond (1990), sought to clarify even further the intent and purpose of teacher evaluation as a collaborative effort by principal and teacher to enhance the quality of teaching in the classroom. Their research emphasized the use of multiple sources of data and evidence such as a portfolio to evaluate the skills of individual teachers rather than the reliance on principal observation as the only evaluation tool (Millman \& Darling-Hammond, 1990). In this case, the role of the principal was extremely important as a collaborator to improve instruction rather than as an evaluator of performance (Millman \& Darling-Hammond, 1990).

By the late 1990's, data did reflect efforts to improve teacher effectiveness through a better evaluation process had resulted in some success in closing the learning gap. Collected data, however, continued to illustrate no state had been able to close the gap completely in all districts (National Center for Education Statistics, 2013). The result of this was a further increase in federal efforts to put pressure on states to continue to improve education opportunities for all and close the learning gap. The No Child Left Behind (NCLB, 2001) legislation again expanded federal support for and influence over 


\section{PRINCIPALS’ PERCEPTIONS}

education and shifted the emphasis away from a focus on compliance with federal and state expectations to one of accountability for end results. NCLB (2001) mandated states would set standards of performance for both students and teachers

As a result of this legislation and a continued failure to close the learning gap, research on teacher evaluation processes also shifted in the late 1990's and early 2000's. Researchers sought to find a way to quantify the skills of a highly effective teacher and began to look for the best methods of evaluating teachers, which would include outcomes produced as reflected in student data resulting from high-stakes testing. The current debate includes how to improve the evaluation process using student data to assess the quality of current teachers to ensure all classrooms have a highly effective teacher. Early research indicated teacher, school, and district value-added could be measured using student growth data and could control for outside factors such as socio-economic and family background (Sanders \& Horn, 1994; Meyer, 1997). A three-year study funded by the Bill and Melinda Gates Foundation, advocates for the use of multiple forms of evaluation for improvement, however, it strongly supports the use of student scores on high-stakes tests as an important component of an accurate method of measuring the skills and abilities of teachers (Gates Foundation, 2013). Current research is mixed on the results of using high-stakes testing results as a part of the teacher evaluation process.

Other research into the use of high-stakes testing and evaluation systems that focus more on accountability based on test results point out they may be counterproductive to providing an opportunity for teacher improvement since teachers may be less likely to reveal weaknesses or ask for help from colleagues or principals (Looney, 2011). In addition, according to Jackson and Bruegmann (2009), there is 


\section{PRINCIPALS’ PERCEPTIONS}

growing evidence that teachers who collaborate and learn from each other about improving instruction are much more effective in the classroom. This requires a great deal of openness and trust between teachers that might be limited in an atmosphere of accountability. Research conducted by Finnigan and Gross (2007) revealed teachers are more driven by the desire to help students than by the promise of rewards or punishments commonly tied to the value-added model of teacher evaluation. This study also identified the potential counterproductive, negative effect high-stakes accountability policies could have on the motivation and morale of teachers over time (Finnigan \& Gross, 2007). According to Looney (2011), teacher evaluation should be balanced between accountability and teacher improvement. For improvement to take place the evaluation process should take into consideration the ever-changing world of education and the need for teachers to continuously update knowledge and skills to better meet the needs of diverse students (Looney, 2011). An analysis of a large body of literature conducted by Hallinger, Heck, and Murphy (2014) focused on the goals of principals to achieve positive results through evaluation. Ultimately, they recommended principals put most of their efforts into non-evaluative activities, such as creating professional communities for teachers to work together, as well as providing on-going feedback and opportunities at high-quality professional development (Hallinger, Heck, \& Murphy, 2014). Despite the differences in results, all of these studies reflect a need for teachers to have support from peers as well as principals, an atmosphere of openness between staff and administration and the opportunity to improve skills through professional development. Improving education for all through teacher evaluations continues to be a highly debated and 


\section{PRINCIPALS’ PERCEPTIONS}

researched topic however; some of the research in this area includes a focus on the skill and abilities of the principal as an instructional leader in the school.

\section{Principals' Perceptions}

Principals are most often the person responsible for conducting observations of all teachers on their staff and making important employment recommendations based on these observations. The literature is somewhat limited and ambiguous on the perceptions of the principals as they conduct interviews of teaching applicants and assess the skills of current personnel to make the best decisions and recommendations for the school. The change from school district compliance with state and federal expectations to one of accountability has changed the focus of classroom observations. More and more districts are including student data as part of assessing the effectiveness of classroom teachers; however, principals still play the most important role in the observation process as they attempt to identify the highly effective teachers in their classrooms (Loeb, Kalogrides, \& Beteille, 2012).

According to a study conducted by Torff and Sessions (2005), principals perceived pedagogical weaknesses, such as lesson planning and implementation, as well as lack of classroom management skills as the most important reasons teachers were ineffective. Principals perceived weaknesses in content knowledge as one of the least important factors for teacher effectiveness (Torff \& Sessions, 2005). Torff and Sessions repeated this study in 2009 with a specific focus on the perceptions of principals in secondary settings where content knowledge in specific subjects is a required part of most traditional teacher certifications. Here as well, the results indicated principals perceived weaknesses in classroom pedagogical skills such as classroom management as 


\section{PRINCIPALS' PERCEPTIONS}

the most important cause of teacher ineffectiveness, followed by weaknesses in lesson planning, with content knowledge weaknesses as the least likely cause of ineffectiveness (Torff \& Sessions, 2009). A more recent study conducted by Nixon, Packard, and Dam(2016) into the reasons for principal non-renewal recommendations also identified lack of instructional skills or pedagogical content knowledge as the most common sign of ineffective teaching and cause for non-renewal.

This perception by principals disagrees with current research, which indicates both pedagogical skill and content knowledge as described earlier, are equally important characteristics of a highly effective teacher (Shulman, 1986; Grossman, 1990; DarlingHammond, 2000; Darling-Hammond, Holtzman, Gatlin, \& Vazquez Heilig, 2005). Along with these characteristics, other studies also emphasize the teacher's ability to make connections with prior knowledge for students, create supports for student learning, continuously assess student learning, along with a strong content knowledge foundation were all characteristics of the most effective teachers (Darling-Hammond, AmreinBeardsley, Haertel, \& Rothstein, 2012; Darling-Hammond \& Youngs, 2002). This discrepancy in what principals' perceive as important teacher characteristics and what the research says about highly effective teachers could have an impact on how principals assess, hire, and assign teachers.

Literature supports the importance of the power of principals to put the right people in the right positions and remove ineffective teachers as an extremely important factor in successful schools (Loeb et al., 2012). A study conducted by Donaldson (2013), however, illustrates principals often feel constrained by teacher contracts, school culture and financial restrictions to hire the best person for the job, move an experienced or 


\section{PRINCIPALS' PERCEPTIONS}

tenured teacher to a different position, or remove a teacher who is not able to meet expected standards. School culture and tradition can also make it difficult to assign teachers to teach where they will be the most effective when seniority deems teachers with experience will be assigned more choice classes while new inexperienced teachers are usually assigned to more challenging classes (Donaldson, 2013).

Research does show when we lift these constraints, principals have the ability to identify teachers based on effectiveness in the classroom (Rivkin, Hanushek, \& Kain, 2005). Additional research indicates principals are also highly influenced by their own personal background, philosophies, and experiences, as well as the thoughts of others, such as assistant principals and other teachers, during the hiring and observing process which can determine the personnel recommendations they make (McGough, 2003; Ingle, Rutledge, \& Bishop, 2011). At the same time principals perceive each opening which must be filled as unique and requiring different teacher characteristics depending on the personalities of the teacher team or department this person would be joining (Ingle et al., 2011). Even with all of these challenges in place, research does show principals have the ability to identify teachers based on effectiveness in the classroom (Rivkin et al., 2005).

\section{Summary}

The body of knowledge developed by educational researchers over the last several decades is immense. The research indicates we can close the learning gap even though there are still differences of opinion on the best method to do so. Throughout the research, however, there is a common thread where many researchers agree a highly effective teacher is an extremely important component in closing the gap and the role of the principal is crucial in identifying highly effective teachers. Research also indicates 


\section{PRINCIPALS’ PERCEPTIONS}

principals, overall, do have a sense of the characteristics of a highly effective teacher even though this research seems to be somewhat limited especially as it relates to the perceptions of rural high school principals. Digging deeper into the principals' perceptions as they attempt to assess the skills of current teachers, hire new teachers, and place the most effective teachers where they are most needed is an extremely important part of continuing to improve education for all. The responsibilities of principals is ever increasing with the many changes in legislation and increased accountability of school districts, individual schools, principals and teachers to show student growth and to use data to reflect improvement in the learning gap. The purpose of this research is to clarify the perceptions of the principals as they attempt to put a highly effective teacher in every classroom.

\section{Current Study}

The purpose of this study was to discover what qualities, characteristics, and skills rural Missouri high school principals perceive teachers must possess to be highly effective. This study focused on the perceptions high school principals have of the characteristics of highly effective teachers during observations of current teachers and throughout an interview for hiring purposes. Understanding the perceptions of principals as they observe current teachers and or work through the process of hiring new teachers could help increase the likelihood school districts will hire and retain the most effective teachers for their classrooms to have the most impact on the learning gap. Through this study, rural Missouri high school principals may gain some insight into their perceptions and an awareness of the impact on the process of identifying highly effective teachers. According to National Center for Education Statistics, the rural school is the most 


\section{PRINCIPALS’ PERCEPTIONS}

common type of high school in Missouri and these schools reflect the values and culture of the communities they serve (Budge, 2006). One very important responsibility of the rural Missouri high school principal is to employ and retain highly effective teachers to provide an excellent education for all students.

Any discrepancy between what the current literature tells us and what this study may discover principals perceive as the characteristics of a highly effective teacher, could help to improve high school principals' ability to identify highly effective teachers. In addition, by analyzing the perceptions of the principals during the interview process we may uncover strengths or weaknesses in the district hiring process, which may help or hinder the ability to identify highly effective teacher applicants. By hiring and retaining highly effective teachers, the school district may be able to close the learning gap, which could reduce the stress on all teachers as well as the principal and all other district personnel.

\section{Research Questions}

The research questions, which guided this study, were,

- What do rural Missouri high school principals perceive to be the qualities, characteristics, and skills of a highly effective teacher in their buildings and do their perceptions align with current research on effective teachers?

- What are the qualities that principals look for when hiring teachers, and how do these principals' expectations align with current research?

These questions focused and drove the framework and design of the study. 


\section{PRINCIPALS’ PERCEPTIONS}

\section{Conceptual/Theoretical Framework}

Identifying and hiring highly effective teachers is the rural Missouri high school principal's most important human resource responsibility. Viewed through the human resource frame, the rural Missouri high school is an organization, which exists to serve the needs of the community and relies heavily on the community and surrounding area to supply the talent and resources it needs to operate (Bolman \& Deal, 2008; Reininger, 2012). According to Bolman and Deal (2008, p. 122), the human resource frame relies on several key assumptions,

- "Organizations exist to serve human needs rather than the converse."

- "People and organizations need each other. Organizations need ideas, energy, and talent; people need careers, salaries, and opportunities."

- "When the fit between individual and system is poor, one or both suffer. Individuals are exploited or exploit the organization-or both become victims."

- "A good fit benefits both. Individuals find meaningful and satisfying work, and organizations get the talent and energy they need to succeed."

These assumptions put a great deal of emphasis on the "fit" of individuals in an organization and in rural Missouri high schools, finding this "fit" is the responsibility of the principal. School boards and community voters determine the hiring guidelines established for the school district and these usually strongly reflect the beliefs of the community at large (Budge, 2006). Along with the human resource framework, this study will use social capital theory to understand the idea of the best "fit" for a building or a specific teaching position. This concept has many definitions but essentially includes the importance of connections within the organization and between the 


\section{PRINCIPALS’ PERCEPTIONS}

organization and the outside community, which can contribute to the strength of the organization (Allan \& Catts, 2014; Putnam, 1995). Rural Missouri high schools are small communities within the larger community they serve and the community expects they will represent their beliefs and values as well as provide an excellent education to their children (Budge, 2006).

The challenge for rural Missouri high school principals is to identify first what qualities and skills a teacher must have to be highly effective and then fairly and accurately identify individual teachers based on these qualities and skills (Hallinger et al., 2014). The role of the principal includes identifying, placing, and supporting highly effective teachers in every classroom. Being able to identify and support highly effective teachers currently in their classrooms may reduce the need to hire a large number of new teachers each year.

Beyond assessing the skills of current teachers, high school principals also have the responsibility of hiring new teachers to fill vacancies as they arise. This involves the ability to assess new applicants for the skills and abilities identified as the characteristics of a highly effective teacher. What do principals perceive and how do they identify the skills of a highly effective teacher while interviewing the applicant? To identify the principals' perceptions of a highly effective teacher, the researcher conducted interviews of eight rural Missouri high school principals who are directly involved in observing current teachers in their buildings and interviewing teachers to hire.

\section{Design of the Study}

The design of this study was as a qualitative case study which Merriam (2009, p. 40), defines as "an in-depth description and analysis of a bounded system". This case 


\section{PRINCIPALS’ PERCEPTIONS}

study focused on the perceptions of eight rural Missouri high school principals of the characteristics of a highly effective teacher. According to Merriam (2009), this design works best for this type of study since the unit of analysis includes eight participants from very similar settings, with a focus on their perceptions of effective teachers. The researcher gathered the information through semi-structured interviews and analyzed the data in an attempt to understand the perceptions of these eight participants

\section{Setting}

The setting for this study was chosen based on data from the Missouri Department of Elementary and Secondary Education (DESE) website which identified the small rural school as the most common type of high school in Missouri with 9-12 student populations of less than 500 (DESE, 2016). The setting for this study included eight rural Missouri public high schools with a population of 200-500 students in grades 9-12, and within a 40-mile radius of the researcher's location. Research also indicates $85 \%$ of teachers tend to work in districts 40 miles or less from their hometowns, which could create a common pool of teachers and teacher applicants for principals within this radius (Boyd, Lankford, Loeb, \& Wickoff, 2005; Reininger, 2012). Choosing schools within a 40-mile radius of the researcher's location could also increase the possibility principals have interviewed some of the same teacher applicants. High school principals are responsible for hiring, observing, and placing a highly effective teacher in every classroom. Understanding the perceptions of the principals as they conduct these observations and interviews could bring to light any discrepancies, which might exist, between what the literature describes as a highly effective teacher and the perceptions of the principals involved in this study. Through semi-structured interviews of principals 


\section{PRINCIPALS' PERCEPTIONS}

directly involved in observing current teachers and hiring future teachers, the researcher gathered data on their perceptions of the qualifications of a highly effective teacher. Currently the literature shows a possible disconnect or discrepancy between what the principals perceive as the skills of a highly effective teacher and what the research reflects.

\section{Participants}

The participants of this study include eight Missouri public high school principals who had at least three years of experience observing and hiring teachers. Missouri Initial Administrator certificate is valid for four years with the first three years considered as the learning period for acquainting themselves with the ins and outs of a new position and the culture of the school (DESE, 2016). At the end of the fourth year, the principal may apply to upgrade to the Transition Administrator Certificate (DESE, 2016). These participants were a small purposive sampling of Missouri high school principals from rural school districts, who have at least three years of experience as a principal, and who are directly involved in the observation and interview process in their districts. The researcher used the Missouri Department of Elementary and Secondary Education (DESE, 2016) website, which includes location, student population, as well as other demographic information of all public school district buildings in the state of Missouri, to choose the school districts for this study. Using this information, the researcher identified thirteen school districts meeting the criteria identified for this study, as well as acquired essential district contact information. The researcher contacted all thirteen principals via email to explain the goal of the research and request their participation in the study. Nine principals responded and one was eliminated due to lack of three years 


\section{PRINCIPALS' PERCEPTIONS}

experience as a high school principal. All eight principals who agreed to participate in the study met all established criteria and were vetted before the study began. All principals received a detailed description of the study, all important contact information, an explanation of rights as participants, as well as information about the complete confidentiality of all information collected for this study, which could identify them as participants. (Appendix A)

All eight schools involved in this study were rural by description according to NCES (2006) and within 15 to 35 miles of a larger town or city. The average 9-12 student body population of the participating schools was 365 with an average of 26 teachers, which created an average of a 14 to 1 teacher/student ratio (DESE, 2016). The demographic data shows a very homogeneous student body with an average of $98 \%$ of the student-body identified as white (DESE, 2016). These schools do differ economically, however, as indicated by the number of students who qualify for the Free and Reduced Lunch program, as determined by student family income. The data shows these schools range from as low as $11 \%$ to as high as $50 \%$ of their students qualifying for the Free and Reduced Lunch Program. In reviewing this data and the location of the schools, there seems to be a connection between the level of need and the distance from a larger town or urban area. The most rural schools, which had the least access to a larger town or urban area, generally had more students who qualified for this program.

Research indicates student poverty can academically affect the success of students in the district and emphasize and even greater need for highly effective teachers (Leithwood, 2010).

See Table 1 for a detailed description of the participants. 
PRINCIPALS' PERCEPTIONS

Table 1. Participants in the Study

\begin{tabular}{|l|l|l|l|l|l|l|}
\hline $\begin{array}{l}\text { School } \\
\text { \& } \\
\text { Principal }\end{array}$ & $\begin{array}{l}\text { Years of } \\
\text { Experience of } \\
\text { the Principal }\end{array}$ & $\begin{array}{l}\text { Number } \\
\text { of } \\
\text { Teachers }\end{array}$ & $\begin{array}{l}\text { Number of } \\
\text { Students in } \\
\text { grades 9- } \\
12\end{array}$ & $\begin{array}{l}\text { Student } \\
\text { Teacher } \\
\text { Ratio }\end{array}$ & $\begin{array}{l}\text { Free and } \\
\text { Reduced } \\
\text { Lunch \% }\end{array}$ & $\begin{array}{l}\text { Demographics } \\
=\% \text { Caucasian } \\
\text { Students }\end{array}$ \\
\hline A & 11 & 23 & 430 & $18.6 / 1$ & 11 & 98 \\
\hline B & 10 & 19 & 280 & $14.7 / 1$ & 50 & 98 \\
\hline C & 9 & 36 & 499 & $13.8 / 1$ & 13 & 94 \\
\hline D & 7 & 28 & 375 & $13.4 / 1$ & 35 & 98 \\
\hline E & 6 & 30 & 405 & $13.5 / 1$ & 22 & 96 \\
\hline F & 8 & 18 & 240 & $13.3 / 1$ & 43 & 99 \\
\hline G & 4 & 32 & 380 & $12 / 1$ & 20 & 100 \\
\hline H & 8 & 24 & 308 & $12.8 / 1$ & 38 & 100 \\
\hline & Avg $=7.87$ & Avg $=26$ & Avg $=365$ & $\begin{array}{l}\text { Avg }= \\
14 / 1\end{array}$ & Avg $=29 \%$ & Avg $=97.87 \%$ \\
\hline
\end{tabular}

The average years of experience of the participating principals was 8 years as head principal and over 20 years of experience in education overall. At least $30 \%$ of the principals reported having taught in the district or a similar district nearby when they were in the classroom themselves, which could have some impact on their perceptions of highly effective teachers. Anecdotal data collected from the principals during our conversations also revealed that anywhere from 41 to $47 \%$ of the teachers in these districts are district graduates or graduated from a nearby community within forty miles of the school. For these districts, this is much lower than the $85 \%$ indicated by research (Boyd et al., 2005; Reininger, 2012). This could be a reflection of a shortage of teachers coming from these areas and the need for these districts to cast a wider net when looking for teacher candidates to fill open positions. This information could influence the analysis of the data on perceptions of principals as they interview teacher candidates.

The researcher will need to focus on the specific characteristics identified by the principal 


\section{PRINCIPALS’ PERCEPTIONS}

as effectiveness and not on the challenges principals faced in finding candidates to interview and potentially hire.

\section{Data Collection Tools}

Data collection began with semi-structured interviews of high school principals, who were directly involved in the process of hiring and observing high school teachers. The purpose of the interviews was to identify what principals perceive as the characteristics of a highly effective teacher during the observation and interview process. This will be compared to what the research says are the characteristics of a highly effective teacher to determine if there are any disagreements between the principals' perceptions and research data. With the permission of the principal, the researcher recorded the interviews and took notes throughout to ensure accurate collection of data. As noted by Merriam (2009), the semi-structured interview formats "assume that individual respondents define the world in unique ways" (p. 90). Each individual principal has a unique experience to share and using a less structured interview allows the researcher to dig deeper into individual perceptions. Using a semi-structured interview process gave the researcher the opportunity to collect similar demographic and background information from all participants while allowing for questions that are more open-ended to guide the interview and truly access the perceptions principals have of a highly effective teacher. The scheduling of all interviews was at the convenience of the principal, and each interview lasted approximately forty-five minutes to an hour. The researcher interviewed three of the eight principals in person in their high school offices and interviewed five principals over the phone. To avoid bias in the interview questions, a small number of principals who were not participating in this study, and who had direct 


\section{PRINCIPALS' PERCEPTIONS}

experience in observing and hiring teachers were asked to review the interview questions prior to the scheduling of interviews for research purposes. (Appendix B)

\section{Data Analysis}

The researcher transcribed interview recordings as quickly as possible following each interview to ensure that notes and memory could assist in deciphering any garbled or unclear recordings. Analysis of these transcriptions began immediately and was on going throughout the research process, which allowed for more focused data collection and improved the quality of data collected from later interviews (Bogdan \& Biklen, 2007). The researcher used a constant inductive and comparative analysis method to identify small pieces of information and analyze the data as it was collected, which meant stopping periodically and highlighting key words and phrases during transcription and immediately upon reading the entire typed transcript (Merriam, 2009). Using this systematic process of collecting small pieces of information along the way, the researcher transcribed each recorded interview and then read over the transcript to make notes and comments in the margins about interesting data that seemed important to the study (Merriam, 2009). The researcher began by highlighting and noting key words and phrases used by principals to identify the characteristics of highly effective teachers. The researcher repeated this process with each transcription and began to compare the notations between transcriptions while looking for any emerging themes in the characteristics identified by principals. After completing all transcriptions and reviewing all of the data, the researcher began to organize the notes into groupings of words that fit specific concepts or skills identified along the way. This open coding analysis process 


\section{PRINCIPALS’ PERCEPTIONS}

was the foundation for creating categories of data, which answered the research questions (Merriam, 2009).

Since the researcher is a high school teacher and department chair, the researcher paid special attention to the analysis process to be aware of any personal biases, which could negatively affect the accurate analysis of the data and presentation of the results. The researcher closely monitored personal assumptions about the characteristics of a highly effective teacher throughout the collection and analysis of the data to control for a possible bias. While analyzing the data, the researcher relied on the current research description of a highly effective teacher to avoid any personal opinions, which may have an effect on the analysis process. The goal was to remain objective and open-minded to the data as the themes and categories emerged.

\section{Limitations, Assumptions, and Design Controls}

This case study was limited to eight rural Missouri high schools with a very similar student body. The results may vary if conducted in large urban schools, or in schools with a much higher level of poverty, where principals may face a more diverse population and possibly less cohesive urban communities and could indicate a need for teachers with a different set of skills to be effective. Other limitations of this study include the fact the researcher is currently a Missouri high school teacher and a department chair, which makes her an "insider" to the system. As a high school teacher, the researcher is subject to observation by a principal and understands the challenges faced by classroom teachers to see an observation as a productive learning opportunity to grow and improve. As a department chair, the researcher is responsible for giving guidance and support to department members as needed. This support could include both 


\section{PRINCIPALS’ PERCEPTIONS}

content knowledge and pedagogical skill, which gives the researcher the opportunity to understand the classroom from the point of view of the principal as well as the teacher. The researcher closely monitored personal assumptions about the characteristics of a highly effective teacher throughout the collection and analysis of the data to control for a possible bias. The researcher tested the interview questions with principals who had experience conducting teacher observations and interviews, and who were not participating in the study, to find flaws or a bias in the questions. As a design control, the researcher conducted all interviews using the same set of interview questions as a guide and with permission, recorded all interviews. This assisted in a more accurate analysis of the data and allowed the researcher to return to the interview itself and not just the written interview notes when necessary. It was helpful to listen to the conversation to clarify the context of a comment in the transcription as well as reconnect with the tone of the interview to analyze what the principal was saying.

\section{Results and Discussion}

\section{Findings}

Results of this study indicate rural Missouri high school principals perceive the pedagogical skills of student engagement and relationships, as well as classroom management as the most important characteristics of highly effective teachers. The principals followed this focus on pedagogy with emphasis on pedagogical content knowledge, like lesson planning and relevance of lessons, but did not include the subject content knowledge of the teacher as an important factor. Whereas, research indicates a highly effective teacher has strong pedagogical skills to manage a classroom, possesses strong subject content knowledge, and can use pedagogical content knowledge to 


\section{PRINCIPALS’ PERCEPTIONS}

effectively teach the content material to all students (Shulman, 1986; Grossman, 1990; Hattie, 2003). When questioned, principals expressed the belief that content knowledge was extremely important to the skill of the teacher in the classroom but was not nearly as important as student engagement, relationship building, and classroom management.

\section{Characteristics of a Highly Effective Teacher as Observed in the Classroom}

When observing current teachers, principal $\mathrm{C}$ referred to it as the "the organized chaos of learning". Principal A described it as an elusive "it factor" or as an atmosphere they could feel when stepping into a highly effective teacher's classroom. These statements are perceptions based on the thinking and feeling of the principal when they think about the characteristics of an effective teacher rather than all three parts of effective teaching as defined by research. Rural Missouri high school principals perceived the teacher's pedagogical skills of student engagement, relationship building, and classroom management as the most important characteristics of the effective teacher's classroom. For the principals, these were interwoven characteristics which if present, led to learning and student growth. The principals emphasized that student engagement in a relevant lesson was extremely important and tied it to the foundation of a well-managed classroom. These principals perceived a well-managed classroom and an atmosphere of mutual respect as the key to engaging students in the learning and the most important characteristic of effective teaching. Six of the eight principals specifically identified student engagement as one of the first things they looked for when entering a classroom. Principal D openly stated that the first thing she looked for when going into a classroom is engagement, "are the students engaged in the class." She went on to say she "loved John Hattie" and felt relationships were the most important factor in the 


\section{PRINCIPALS’ PERCEPTIONS}

classroom, which she continued to weave together with engagement throughout the interview. Principal B stated, "[Effective teachers] have to be able to engage the students. Need to find those people who just inspire but that also means they make connections to relevance." According to principal C, "An effective teacher could mean a lot of different things and your style and his style could be totally different and the rooms totally different and both dynamite. It's really tough; somewhere you have to be making a connection with your students... I think ... somewhere along the line you have to have a level of student engagement in your classroom." "The most effective teacher exhibits enthusiasm for students and the content. Students are engaged in the content and teachers are communicating the content," according to Principal H, which indicates more of an awareness of the pedagogical content knowledge of the teacher by this principal.

Two principals included the engagement of the teacher in their description of effective teaching. Principal F said, "The first thing I look for is, are they [the teacher] up actively teaching. The teacher is up actively teaching and engaged with the class. Student engagement is huge." Principal F also said, "I need my teachers 100\% engaged in there, you know, not at their desk or not doing something on the side that doesn't pertain to the group."

Three principals put a heavy emphasis on the relationship side of teacher classroom management. Principal A stated that one of the most important components was "The relationship piece. I'm talking about a relationship where that teacher may not be the students' favorite teacher but they know that that teacher is going to make them work hard, have high expectations, hold them accountable and be consistent. Work their tails off but care about them." According to Principal C, "At some level there has to be 


\section{PRINCIPALS’ PERCEPTIONS}

that connection with students. Without that you probably aren't going to be effective." "Their relationships with kids and their relationships with co-workers when they are not in the instructional classroom. You know, our most effective teachers are the ones that are the most visible in the hallways between classes, and talk with students and interact with students in an informal manner, you know in a professional way. I think they are the ones who are most likely to have a conversation in the teacher's lounge or in the work-room, you know, share information, teachers talking about student issues," stated Principal E.

At least two principals specifically identified communication skills as key to relationships and effective teaching. "Ability to communicate with students, confident in their subject matter, able to build relationships while still maintaining, uh, a pretty organized classroom, you know. Organized probably isn't the word, but well, wellmanaged classroom where students feel safe," according to Principal F. According to Principal H, "Connections include communication skills and a student-centered focus. They are great communicators with students and staff and model expectations in the classroom. The most important characteristic is that they teach students first over anything else." For these principals the emphasis seemed to be on the pedagogical foundation skills of relationships, engagement, and communication.

Other more basic procedural types of pedagogical skill emphasized during the interviews by most of the principals as characteristics of effective teachers included good classroom management skills and strong lesson planning and delivery. At least two principals specifically referred to the Madeline Hunter model of teaching as an effective process for good planning, preparation, and delivery of the content. Principal A 


\section{PRINCIPALS' PERCEPTIONS}

specifically said, "Planning and preparation clearly evident. Is there intentional planning, you know the old classic Madeline Hunter model. You know, do you tell them what you want them to know by the end of the period? I expect my teachers to have, you know, proper classroom management, well-planned instructional activities, and teach bell to bell." "A well-managed classroom is where kids feel safe. For me, that's what's wrong with an out of control classroom is that two or three or four are disruptive and the other sixteen don't feel very safe," stated Principal F. "I'm a firm believer in procedure. If you can't manage the room, then you can't even manage a lesson," Principal B. "I love to hear Madeline Hunter ... I like to hear, do they think about a beginning, a middle, and end of the lesson," Principal D. Other principals described a similar structure, for example Principal A states, "You should be able to see some direction, there's a method to their madness, umm, you know, they know where they are going, the kids seem to understand what's going on."

There is an obvious focus on the pedagogical skills of relationships and student engagement in the comments made by these principals. At the same time, many of the principals' comments also identify their own experiences and learning as influences on their perceptions. The references to Madeline Hunter whose research guided teacher preparation programs for decades, when referring to planning lessons and teaching bell to bell as a part of effective teaching reflects some of their professional training. Their reference to the more recent work of John Hattie when discussing relationships, as part of how they judge the effectiveness of the classroom teacher identifies the influence of their own current learning and possible professional development on their view of effective teaching. 


\section{PRINCIPALS’ PERCEPTIONS}

When questioned about the importance of content knowledge seven of the eight principals indicated subject content knowledge was extremely important in giving the teacher the grounding or foundation needed to be effective teachers and impart content knowledge. Two principals actually said they would put content knowledge first but were quick to add that content was useless without the pedagogical skills to deliver content in the classroom. Principal B stated, "Content has to be first and then their personalities and how it connects comes in behind it. How they motivate and engage kids - but they gotta know their stuff." On the other hand, however, Principal A believes, "You do have to know your content but none of that is going to mean anything if you don't have a lesson well planned with varying levels of rigor and examples." Six of the eight principals, however, placed the content knowledge of the teacher as a close second or possibly third if forced to rank as a skill needed to be an effective teacher. Two principals even commented that they believed someone who had the pedagogical knowledge of classroom management and planning could increase their content knowledge more efficiently along the way, than someone who might need to improve their pedagogical skills. Three principals stated that in the end pedagogical skills outweighed content knowledge in an effective teacher's classroom. "Content knowledge, it's important, but it's not number one. I mean the ability to run a classroom, the ability to collaborate with your peers, interact with, engage your students is most important," according to Principal C. He went on to add, however, "If you don't know your subject matter you're gonna be exposed at some point. On the other hand if you don't like kids and you can't work with students you're gonna also get exposed. So you know, they probably walk hand in hand. They both have to be in place but if I had to 


\section{PRINCIPALS’ PERCEPTIONS}

lean one way or the other, I would lean toward that person, the engagement piece with the students, the connection has to be there." Principal E states, "I would say that content knowledge is, you know, right there with critical planning. I think that being able to engage kids ultimately is a baseline thing, I mean you can learn content knowledge." Principal D had a different view of content by saying "It's important they have a passion for their content but kids must be most important to them. Kids are their focus." Finally, Principal G strongly stated, “I definitely don't think it's [content] number one because there's some very bright people that know their stuff who can't teach a lick."

The results of this study indicate rural Missouri principals believe content knowledge is extremely important in the effective teacher's classroom but it is not as important as strong pedagogical knowledge and pedagogical content knowledge. Almost all of the descriptors of effective teaching used by these principals fell into the pedagogical category of classroom management or pedagogical content knowledge category, which includes the ability to engage students in a well-planned lesson. Even discussions of teacher subject content knowledge came back to engagement, as well as teacher enthusiasm for the content, and not the actual content itself.

These comments and perceptions of the rural Missouri high school principals seem to reflect a common use of terminology such as engagement, connections, and learning environment with a heavy focus on pedagogical content knowledge and skill. According to principals, more modern observation practices include shorter more frequent walk-through observations rather than the more traditional longer observations of the PBTE. Most reported the increased frequency was a better method of seeing teachers in action and stimulated more productive, less formal conversations about what 


\section{PRINCIPALS’ PERCEPTIONS}

was going on in the classroom. Two principals, however, described a process of both long and short observations due to a lack of understanding about the process by teachers and the principals' lack of time to complete as many visits as they wanted. Surprisingly, however, none of the principals described doing exactly the same thing as another principal in this study. Each district had a slightly different method for conducting teacher observations.

I was surprised by the heavy focus on student engagement and the reliance on how the principal "feels", or their instincts, when in the company an "effective" teacher. Some of these same ideas and attitudes carried over into the hiring process as well. Similar to the observation process, when interviewing teachers, principals focused more on the pedagogical skills of classroom management and lesson planning, as well as personality traits such as honest, humble, and caring, and focused much less on specific subject content knowledge.

\section{Characteristics of a Highly Effective Teacher as Identified During an Interview}

During the interview process rural Missouri high school principals identified the ability to manage a classroom, which includes lesson planning skills, and the ability to build relationships, which includes engaging students as the two most important characteristics of an effective teacher. This is almost exactly the same characteristics as were identified for highly effective teachers already in the classroom. A third characteristic or category of characteristics of an effective teacher emphasized by principals, however, were personality traits such as enthusiastic, honest, and caring. Rural Missouri high school principals did not specifically focus on these traits or characteristics when talking about teachers already in the classroom. 


\section{PRINCIPALS' PERCEPTIONS}

All principals in this study described a similar and yet slightly different process for choosing and interviewing teacher candidates. All were in charge of vetting the applications, choosing the candidates, and conducting the interviews. Three of the eight did specifically identify including the assistant principal and possibly a content teacher as an interview committee if time and availability allowed. Before they can focus on these characteristics, the principals involved in this study, identified narrowing the applicant pool as the first step in the interviewing and hiring process, and then choosing applicants to interview. For smaller, more rural Missouri high schools, however, that meant they might have to interview all of the three or four candidates who applied in hopes of finding a strong effective teacher in the mix. Occasionally the challenge is even greater for the most remote districts, when no one applies, which can occur in the areas of math and science especially. When districts do have multiple applications, however, the quality of the completed application itself can determine the next step. All of the principals said they would automatically cut an applicant who had submitted a sloppy or carelessly completed application, which included typos and poor grammar. They questioned the work ethic and caring of the applicant toward the job if they were so careless with their first impression. The principals would also avoid any applicant who seemed to have a history of job-hopping, a history of only a year at a school, for fear they would be getting an extremely weak, unreliable teacher and would only have to replace that person in a year. Good grades were also important, especially in their content areas and methods classes when deciding which applicants to interview. Grades in student teaching, however, were only important if the candidate had received a grade below a B. Three principals actually expressed some doubt that there was any real meaning in either 


\section{PRINCIPALS’ PERCEPTIONS}

an $\mathrm{A}$ or a B in student teaching. Receiving a $\mathrm{C}$ or less, however, was a red flag that something did not go well during student teaching and indicated this candidate probably had weak pedagogical skill and pedagogical content knowledge and would not do well as a teacher in the classroom.

Once the principals have chosen applicants to interview, most principals were interested in the pedagogical skills applicants have to engage students and manage a classroom. Principal G states, "Good teachers, I think, just do the whole big picture. You know, the management, the planning, the curriculum, it's all kind of coming together to form you as a teacher." Principal A is looking for "The type of person who can come in and command a classroom and be professional and be respectful." At the same time, he included personality traits he felt were important for the person to fit into his building, "has a personality, can build relationships, are humble, straight forward. Nothing aggravates me more, especially with these new ones coming in, and trying to use all of these educational acronyms and playing that education bingo. I want someone who is just real, humble." In an attempt to assess pedagogical skill and true personality of the applicant, two of the eight schools participating in this study have applicants schedule a time to teach part of a lesson as an important part of the interview process. These two districts use this activity to identify the applicant's classroom management skills, and pedagogical content skills, as well as address the concern the new hire "fit" the current culture of the school, relate to other staff, and have a "positive, caring personality in the classroom," according to Principal C. All of the principals interviewed indicated the need for an applicant to "fit" into the culture of the team or building as an important consideration. Principal B even indicated his school board expected him to hire more 


\section{PRINCIPALS' PERCEPTIONS}

local people or people from areas nearby in order to minimize turnover. He struggled with this in hard to fill jobs, especially band and choir director positions or higher-level math and science positions.

During the interview of the principals, when the focus of our conversation turned to the content knowledge of the applicant, like the results of current classroom observations, principals were more interested in the excitement the candidate showed about teaching the material and a general interest they had in the content area rather than the level of content knowledge itself. Principals actually expressed concern about teachers who were brilliant in the content but did not possess pedagogical skills to manage a classroom, plan an engaging lesson, or impart the knowledge in a manner that was understandable by the students. They commented that some of the alternative methods of certifying teachers in Missouri today were producing teachers who do not have enough general teaching skills or teaching skills in the content area that they received an additional certification in to teach multiple topics. Principals seemed to agree that, for example, a teacher who holds a traditional Missouri certification to teach high school science might not have the skills to teach high school English just by getting the additional content certification in that area. They agreed that there is a great need to increase the number and quality of teachers in our schools today, however, they also emphasized that having time in the content area classroom before certification was vital to the effectiveness and overall success of the teacher in the classroom. Three of the principals specifically indicated they were more likely to hire someone with a traditional degree and teaching certificate over an equal candidate who had gone an alternative route into teaching. 
See Table 2 for a detailed list of the characteristics of an effective teacher as

principals conduct interviews to fill open teaching positions.

Table 2. Characteristics of an Effective Teacher Applicant

\begin{tabular}{|c|c|}
\hline Interviews & What are you looking for in an effective teacher applicant? \\
\hline $\begin{array}{l}\text { Planning, } \\
\text { Preparation, } \\
\text { and } \\
\text { Management }\end{array}$ & $\begin{array}{l}\text { Not afraid to get their hands dirty. } \\
\text { Lesson planning skills - Instructional strategies. } \\
\text { Describe best lesson and worst lesson - are they reflective? } \\
\text { Differentiated classroom ideas - meet the needs of all kids. } \\
\text { How do they evaluate student growth? } \\
\text { Don't blame student failure or lack of success on others, kids, etc. } \\
\text { They understand how the whole picture - Management, planning, } \\
\text { curriculum and it comes together to form you the teacher. } \\
\text { Classroom management ability without continuous support - Low } \\
\text { maintenance. } \\
\text { Classroom management - What is their first response to a student cheating } \\
\text { or crying? }\end{array}$ \\
\hline $\begin{array}{l}\text { Student } \\
\text { Engagement, } \\
\text { Relationships, } \\
\text { and } \\
\text { communication } \\
\text { skills }\end{array}$ & $\begin{array}{l}\text { Can they describe their classroom? What are they doing? What are the } \\
\text { kids doing? } \\
\text { Emphasis on communication with kids. } \\
\text { Must fit the school culture - shared leadership - Must get along. } \\
\text { Do they talk about what is best for students? } \\
\text { How well do they articulate thoughts } \\
\text { Do they put kids first? } \\
\text { Do they make a good connection with those who interview them } \\
\text { Do they fit in with the culture and expectations of team or department? } \\
\text { Able to deal with parents effectively } \\
\text { Require candidate to teach a lesson - Can they build a rapport with the } \\
\text { students and conduct a lesson. } \\
\text { What are their thoughts on contact with parents? } \\
\text { Show me that you can relate what you know to real life in your lessons. } \\
\text { Good teachers I think just do the whole big picture. You know, the } \\
\text { management, the planning, the curriculum, it's all kind of coming together } \\
\text { to form you as a teacher. }\end{array}$ \\
\hline Personality & $\begin{array}{l}\text { Personality - Looking for a "kid magnet" - Which one of those folks do you } \\
\text { feel like kids are going to respond to? } \\
\text { Be themselves - Honesty. } \\
\text { Humble and straight forward. } \\
\text { Steady. } \\
\text { Seem to care about kids. } \\
\text { Genuine } \\
\text { Seem interested in the job. Why do they want to teach here? } \\
\text { Look for the best person for that specific room. } \\
\text { Are they a fit for the team (PLC team) } \\
\text { Moldable }\end{array}$ \\
\hline
\end{tabular}




\begin{tabular}{|c|c|}
\hline & $\begin{array}{l}\text { Personality to relate to kids and parents and teachers } \\
\text { How they come across - pleasant, positive, are they willing to share? } \\
\text { Personality and good content knowledge make a good teacher. } \\
\text { A little bit quirky - teach a little differently } \\
\text { Sees the big picture } \\
\text { Can list their strengths AND their weaknesses. } \\
\text { Being honest with who you are. } \\
\text { Transparency } \\
\text { Enthusiastic } \\
\text { Personality, professionalism, real, relationship builder } \\
\text { Fit it with the school culture }\end{array}$ \\
\hline Content & $\begin{array}{l}\text { Excitement about content } \\
\text { Ask content questions - looking for passion. } \\
\text { Personality and good content knowledge make a good teacher. } \\
\text { They are not only enthusiastic but they have good knowledge }\end{array}$ \\
\hline Other Skills & $\begin{array}{l}\text { Diverse skills - more than teaching. Need people to fill multiple roles } \\
\text { (small school) } \\
\text { Have something they can and will do with clubs or sports after school. } \\
\text { How do they measure their own growth? Are they reflective learner? }\end{array}$ \\
\hline
\end{tabular}

As a part of our conversations about the characteristics of an effective teacher, principals also shared their thoughts on the "red flags" they felt were obvious signs of ineffective teachers. Here to, the emphasis is on pedagogical knowledge and pedagogical content knowledge and does not focus on the subject content knowledge of the teacher which supports the results of the studies conducted by Torff and Sessions $(2005,2009)$ as well as the study conducted by Nixon, Packard, and Dam (2016).

\section{Red Flags of Ineffectiveness}

"Unorganized, unprofessional, and lazy" were the most common descriptors used when asked to describe an ineffective teacher. Most commented that a messy chaotic room did not necessarily indicate ineffectiveness but a disengaged, unprepared teacher with a chaotic room was definitely an ineffective teacher. Principals felt this indicated the teacher did not plan well for the lesson and did not have a way to engage students in the learning. Below is a list of the characteristics of an ineffective teacher, as identified 


\section{PRINCIPALS’ PERCEPTIONS}

by these eight principals. Some of these statements, such as "Young teachers unwilling to do more than teach" (Principal B), may reflect the unique needs of a rural Missouri high school for teachers to have more than one responsibility in the school, such as teaching and coaching, in order to provide all of the opportunities for students expected by the community.

See Table 3 for a list of characteristics principals perceive indicate an ineffective teacher in the classroom and during an interview.

Table 3. - "Red Flags" - Characteristics of an Ineffective Teacher

\begin{tabular}{|c|c|}
\hline Group & Red Flags or Characteristics of an Ineffective Teacher \\
\hline $\begin{array}{l}\text { Teachers in the } \\
\text { classroom }\end{array}$ & $\begin{array}{l}\text { Not very organized } \\
\text { Not very professional } \\
\text { Lazy - don't plan } \\
\text { Teachers who are rushing in at the last minute or always prepping or } \\
\text { grading between classes. } \\
\text { Constantly working late - could be a sign of stress or overload } \\
\text { Seen over time - sitting behind the desk too much, typing on the } \\
\text { computer, Not interacting with students, and not walking around helping } \\
\text { them. This is a lack of preparation - Not prepared - Working on their } \\
\text { stuff. } \\
\text { Student workday - No teacher interaction - Teacher wastes time causes } \\
\text { kids to misbehave. } \\
\text { Teachers who are not student centered. Entitled attitude, Not a team } \\
\text { player. } \\
\text { Selfishness - school or kids owe me something attitude. } \\
\text { Gut feeling when you walk into the classroom that things just ratcheted up } \\
\text { a notch because you just walked in. Kids are being snapped out of their } \\
\text { slumber. } \\
\text { Sometimes technology is a crutch or a time filler. } \\
\text { Frustrated or growly teacher - feels they can't get their point across or } \\
\text { they can't get kids to score well or even do their work - unpleasant } \\
\text { atmosphere - teacher who is sick of education. } \\
\text { Less effective teachers see teaching in separate parts - Management, } \\
\text { planning, curriculum as separate things. } \\
\text { Tolerate or ignore disruptive behaviors that distract learners } \\
\text { Too little communication } \\
\text { Too little follow through with expectations }\end{array}$ \\
\hline $\begin{array}{l}\text { Teacher } \\
\text { Applicants }\end{array}$ & $\begin{array}{l}\text { Alternative certification - no methods classes } \\
\text { Poor grammar on applications } \\
\text { Misspelled words }\end{array}$ \\
\hline
\end{tabular}




\begin{tabular}{|l|l|}
\hline & $\begin{array}{l}\text { Resume is junk - poorly written with bad grammar } \\
\text { Copy and paste errors on application or resume - Not paying attention or } \\
\text { just don't care. } \\
\text { Young teachers unwilling to do more than teach. } \\
\text { Gut response - they aren't exciting to me. } \\
\text { They are not dynamic and I wouldn't want kids to spend time with them. } \\
\text { Why has someone been in } 12 \text { schools in } 13 \text { years or why are they leaving } \\
\text { after just one year - were they non-renewed? } \\
\text { Teacher applicants with praxis certification and has not majored or } \\
\text { student taught in those subject areas. } \\
\text { Low grades (C-F) in subject matter. }\end{array}$ \\
\hline
\end{tabular}

\section{Discussion}

The results of this study show that principals put a heavy emphasis on pedagogical skills such as classroom management and student engagement as the most important indicator of teacher effectiveness or ineffectiveness as identified by Torff and Sessions (2005 \& 2009) as well as Nixon, Packard, and Dam (2016). This study identifies a difference in what research says an effective teacher is and what principals perceive as an effective teacher. Both research and principals identify strong pedagogical knowledge and pedagogical content knowledge, such as lesson planning, as extremely important for effective teaching. The research included in this study, however, puts an equal emphasis on pedagogical knowledge, pedagogical content knowledge and the subject content knowledge of a teacher to indicate effectiveness, (Shulman, 1986; Grossman, 1990; Darling-Hammond, 2000; Darling-Hammond et al., 2005). In talking to rural Missouri high school principals about what they perceive as the most effective teachers, their first comments tended to reflect the pedagogical knowledge and training of teachers, while they all seem to believe that content skill is very important, it did not appear in their comments about an effective teacher without direct questioning. Research indicates that pedagogical skill and pedagogical content knowledge, as well as strong 


\section{PRINCIPALS’ PERCEPTIONS}

content knowledge together are equally important for teachers to be effective (DarlingHammond, 2000; Shulman, 1986). Effective teachers must be able to manage a classroom, understand and know well the content they teach, the curriculum attached to that content, and be able to plan effective, engaging lessons to teach the content in multiple ways for all student to learn (Shulman, 1986; Grossman, 1990; DarlingHammond, 2000; Darling-Hammond et al., 2005; Hattie, 2003).

When asked about identifying the content strength of the teacher, principals did feel this was a challenge, however, most felt that they could see evidence of content knowledge strength in the quality of the lesson planning and the teacher/student interaction throughout the lesson. These findings indicate principals may be paying attention to content through the pedagogical lens of lesson planning but in reality, content knowledge does not seem to get the same focus as the pedagogical content skills of content delivery. Principals emphasized the fact they believed content knowledge was very important and made the teacher's job of engaging students and teaching a lesson much easier if they had confidence in the content. Three specifically noted the increased reliance on Professional Learning Communities (PLC's) in their schools, which allows subject content teams to collaborate and support each other in both content subject knowledge and pedagogical content knowledge. Not all schools in the study, however, have the resources to provide the additional time for teachers to work in PLC teams or a large enough staff to create teams.

Principals also seem to have similar perceptions of prospective teachers when conducting interviews. Two specifically expressed concern about the alternative methods of teacher certification, which may allow someone to teach a subject without pedagogical 


\section{PRINCIPALS’ PERCEPTIONS}

training or teaching experience in the content area. They also placed heavy emphasis on classroom management, lesson planning skills, and concerns of fit for the culture of the school and community when planning to hire a prospective teacher. Many comments made about the hiring of someone for an open position when talking about fit seemed to be about the personality of the applicant rather than skill. The human resource frame and social capital theory put a great deal of emphasis on the "fit" of individuals in an organization and in rural Missouri high schools, finding this "fit" is the responsibility of the principal (Allan \& Catts, 2014; Bolman \& Deal, 2008; Putnam, 1995). Seven of the eight principals spoke of their schools and teachers in positive, collegial fashion where the teachers were caring and responsive to principal leadership and guidance and worked well together. This could indicate that principals have been able to find the correct "fit" for the school but does not necessarily indicate effectiveness of teachers. School boards and community voters determine the hiring guidelines established for the school district and these usually strongly reflect the beliefs of the community at large. Rural Missouri high schools are small communities within the larger community they serve and the community expects they will represent their beliefs and values as well as provide an excellent education to their children.

\section{Recommendations}

This study indicates principals do understand and know the characteristics of effective teachers but are not necessarily focusing on the subject content knowledge of the teacher when observing and hiring teachers. An effective teacher, according to research has strong pedagogical knowledge, pedagogical content knowledge, and subject content knowledge (Darling-Hammond et al., 2012; Hattie, 2003; Shulman, 1986). The 


\section{PRINCIPALS' PERCEPTIONS}

researcher recommends the following steps to ensure a highly effective teacher is in every classroom.

- Where and when possible, create teacher teams to discuss the specific curriculum content to be taught for each unit of teaching. Create common lessons, as well as formative and summative assessments as a team to increase the content knowledge and provide content support for those who struggle. Collaboration among teachers could also provide novice teachers with more support to become highly effective teachers over time.

- Review the professional development provided at the state and local level to provide content specific professional development opportunities for teachers throughout the school year.

- When possible, the principal could collaborate with a content area teacher, especially the department chair as the teacher leader, to conduct walk-through observations to provide feedback on both pedagogy and content to the observed teacher. Since the principal probably is not a content expert in all areas he or she is expected to observe and assess, it is vital that someone with more knowledge assist in giving constructive subject content feedback to teachers. These should be non-evaluative, feedback only opportunities.

- Assess hiring practices and provide guidance to school board members on the characteristics of highly effective teachers, to better inform their hiring policy decisions. School board members need to know what makes up an effective teacher and should use these characteristics from research to review hiring expectations and guidelines in place. 


\section{PRINCIPALS’ PERCEPTIONS}

\section{Conclusion}

As the most common type of high school in the state of Missouri, it is critical that rural Missouri high school principals accurately identify and hire highly effective teachers. Principals work hard to identify highly effective teachers as they observe classroom teachers and conduct interviews to hire prospective teachers. The challenge for rural Missouri high school principals is to ensure they are accurately identifying highly effective teachers who have strong pedagogical knowledge, pedagogical content knowledge, as well as strength in subject content knowledge. Rural Missouri high school principals are the most important link between the highly effective teacher and placement in a classroom where students can have access to an excellent education.

\section{Future Research}

This study could be expanded to include more principals in similar districts to compare the data and determine if all rural high school principals put emphasis on pedagogy and pedagogical content knowledge over subject content knowledge when identifying effective teachers. A replication of this study in larger more urban districts might be useful in determining any similarities or differences in the perceptions of urban principals as compared to the principals of rural schools. This study should also be conducted at the elementary level where subject content knowledge expectations are broader and more diverse. Principals in the elementary setting could have a different perspective of highly effective teachers assessing the skills of current teachers and hiring future teachers.

Conducting research into the accuracy of the perceptions of the principals as compared to their overall growth or improvement as a school district might also be useful 


\section{PRINCIPALS' PERCEPTIONS}

data. As the link between the classroom and the placement of effective teachers, the principal's perceptions play a vital role in all students having access to highly effective teachers.

Other important areas requiring further study or examination include the impact of student/teacher relationships and engagement on student achievement. Principals repeatedly identified these two areas as extremely important characteristics of highly effective teachers. Other areas of study include the impact of teacher tenure on education improvement efforts. Tenured teachers do tend to have more autonomy in the classroom and could have both positive and negative impact on efforts to improve or change classroom instruction. All of these areas of study could affect the placement of highly effective teachers in every classroom. 


\section{PRINCIPALS’ PERCEPTIONS}

\section{References}

A Nation at Risk Report: An Imperative for Educational Reform, April 1983. Retrieved from https://www2.ed.gov/pubs/NatAtRisk/risk.html

Allan, J., \& Catts, R. (2014). Schools, social capital and space. Cambridge Journal of Education, 44(2), 217-228. http://dx.doi.org/10.1080/0305764X.2013.863829

Austin, G. (1979). Exemplary schools and the search for effectiveness. Educational Leadership, October, 10-14.

Bogdan, R. C., \& Biklen, S. K. (2007). Qualitative research for education: An introduction to theories and methods. Boston, MA: Pearson.

Bolman, L., \& Deal, T. (2008). Reframing organizations: Artistry, choice, and leadership. San Francisco, CA: Jossey-Bass.

Boyd, E., Lankford, H., Loeb, S., \& Wyckoff, J. (2005). The draw of home: How teachers' preferences for proximity disadvantage urban schools. Journal of Policy Analysis and Management, 24(1), 113-132.

Budge, K. (2006). Rural leaders, rural places: Problem, privilege, and possibility. Journal of Research in Rural Education, 21(13), 1-10.

Darling-Hammond, L. (2000). Teacher quality and student achievement. Education Policy Analysis Archives, 8(1), 1-44. doi:http://dx.doi.org/10.14507/epaa.v8n1.2000.

Darling-Hammond, L., Amrein-Beardsley, A., Haertel, E., \& Rothstein, J. (2012). Evaluating teacher evaluation. The Phi Delta Kappan, 93(6), 8-15.

Darling-Hammond, L., Holtzman, D. J., Gatlin, S. J., \& Vazquez Heilig, J. (2005). Does 


\section{PRINCIPALS’ PERCEPTIONS}

teacher preparation matter? Evidence about teacher certification, teach for America, and teacher effectiveness. Education Policy Analysis Archives, 15, 151.

Darling-Hammond, L., Wise, A. E., \& Pease, S. R. (1983). Teacher evaluation in the organizational context: A review of the literature. Review of Educational Research, 53(3), 285-328. doi:10.3102/00346543053003285.

Darling-Hammond, L., \& Youngs, P. (2002). Defining "highly effective teachers": What does "scientifically-based research" actually tell us? Educational Researcher. 31(9), 13-25.

Donaldson, M. (2013). Principals' approaches to cultivating teacher effectiveness:

Constraints and opportunities in hiring, assigning, evaluating, and developing teachers. Educational Administration Quarterly, 49(5), 838-882. doi:10.1177/0013161X13485961.

ESSA - Every Student Succeeds Act: A progress report on elementary and secondary education, (2015). Retrieved from https://www.whitehouse.gov/sites/whitehouse.gov/files/documents/ ESSA_Progress_Report.pdf

Finnigan, K., \& Gross, B. (2007). Do accountability policy sanctions influence teacher motivation? Lesson's from Chicago's low-performing schools. American Educational Research Journal, 44(3), 594-629.

Gates Foundation (2013). Measures of effective teaching. Retrieved from http://www.gatesfoundation.org/Media-Center/Press-Releases/2013/01/Measures of-Effective-Teaching-Project-Releases-Final-Research-Report. 


\section{PRINCIPALS’ PERCEPTIONS}

Gitlin, A., \& Smyth, J. (1989). Teacher evaluation: Educative alternatives. Philadelphia, PA: Falmer Press, Taylor \& Francis, Inc.

Gamoran, A., \& Long, D. (2006). Equality of educational opportunity: A 40-year retrospective. WCER Working Paper, 2006-9 (Madison, WI, Wisconsin Center for Education Research).

Grossman, P. (1990). The making of a teacher: Teacher knowledge and teacher education. New York, NY: Teachers College Press.

Hallinger, P., Heck, R., \& Murphy, J. (2014). Teacher evaluation and school improvement: An analysis of the evidence. Educational Assessment, Evaluation and Accountability, 26, 5-28. doi:10.1007/s11092-013-9179-5.

Hattie, J.A. (2003, October). Teachers make a difference: What is the research evidence? Paper presented at the Building Teacher Quality: What does the research tell us? ACER Research Conference, Melbourne, Australia. Retrieved from http://research.acer.edu.au/research_conference_2003/4/

Holland, H. (2007). Can educators close the achievement gap? An interview with Richard Rothstein and Kati Haycock. National Staff Development Council, 28(1), 54-62.

Ingle, K., Rutledge, S., \& Bishop, J., (2011). Context matters: Principals’ sensemaking of teacher hiring and on-the-job performance. Journal of Educational Administration, 49(5), 579-610. doi:10.1108/09578231111159557.

Jackson, C. K., \& Bruegmann, E. (2009). Teaching Students and Teaching Each Other: the importance of peer learning for teachers. NBER Working Paper, 15202 (Cambridge, MA, National Bureau of Economic Research). 


\section{PRINCIPALS' PERCEPTIONS}

Jencks, C., \& Phillips, M. (1998). The black-white test score gap. Washington, DC: Brookings Institution Press

Leithwood, K. (2010). Characteristics of school districts that are exceptionally effective in closing the achievement gap. Leadership and Policy in Schools, 9, 245-291. doi:10.1080/15700761003731500.

Lewis, A. (1982). Evaluating educational personnel. Arlington, VA: American Association of School Principals.

Loeb, S., Kalogrides, D., \& Beteille, T. (2012). Effective schools: Teacher hiring, assignment, development and retention. Education Finance and Policy, 7(3), 269-304.

Looney, J. (2011). Developing high-quality teachers: Teacher evaluation for improvement. European Journal of Education, 46(4), 440-455.

McGough, D. (2003). Leaders as learners: An inquiry into the formation and transformation of principals' professional perspectives. Educational Evaluation and Policy Analysis, 25(4), 449-471.

McLaughlin, M. W., \& Pfeifer, R. S. (1988). Teacher evaluation: Improvement, accountability, and effective learning. New York, NY: Teachers College Press.

Merriam, S. (2009). Qualitative research: A guide to design and implementation. San Francisco, CA: Jossey-Bass.

Meyer, R. (1997). Value added indicators of school performance: A primer. Economics of Education Review, 16(3), 283-301.

Millman, J., \& Darling-Hammond, L. (1990). The new handbook of teacher evaluation: Assessing elementary and secondary school teachers. Thousand Oaks, CA: 


\section{PRINCIPALS' PERCEPTIONS}

Corwin Press; a SAGE Publications Company.

Missouri Department of Elementary and Secondary Education (2016). Retrieved from http://mcds.dese.mo.gov/quickfacts/SitePages/DistrictInfo.aspx

Missouri Department of Elementary and Secondary Education (2016). Administrator Certification. Retrieved from https://dese.mo.gov/educatorquality/certification/administrator-upgraderequirements.

National Center for Education Statistics (2006). Rural Education in America. National Center for Education Statistics, Institute of Education Sciences, U.S. Department of Education, Washington, D.C. Retrieved from https://nces.ed.gov/surveys/ruraled/definitions.asp.

National Center for Education Statistics (2013). The Nation's Report Card: Trends in Academic Progress 2012 (NCES 2013-456). National Center for Education Statistics, Institute of Education Sciences, U.S. Department of Education, Washington, D.C. Retrieved from http://nces.ed.gov/nationsreportcard/subject/publications/main2012/pdf.

Nixon, A., Packard, A., \& Dam, M. (2016). Teacher contract non-renewal: What matters to principals? International Journal of Educational Leadership Preparation, 11(1).

No Child Left Behind Act of 2001. Public Law Number 107-110 (2001). Retrieved from www2.ed.gov/nclb/landing.jhtml.

Noguera, P. (2007). Closing the racial achievement gap: The best strategies of the schools we send them to. In Motion Magazine, published online. Retrieved from 


\section{PRINCIPALS' PERCEPTIONS}

http://www.inmotionmagazine.com/er/pn_strat.html.

Putnam, R. (1995). Tuning In, Tuning Out: The Strange Disappearance of Social Capital in America. Political Science and Politics, 28(4), 664-683.

Reininger, M. (2012). Hometown disadvantage? It depends on where you're from: Teachers' location preferences and the implications for staffing schools. Educational Evaluation and Policy Analysis, 34(2), 127-145.

Rivkin, S., Hanushek, E., \& Kain, J. (2005). Teachers, schools, and academic achievement. Econometrica, 73(2), 417-458.

Rojas-LeBouef, A., \& Slate, J. R. (2011). The achievement gap between white and nonwhite students: A conceptual analysis. International Journal of Educational Leadership Preparation, 6(4). Retrieved from http://cnx.org/content/m41405/1.1/

Sanders, W., \& Horn, S. (1994). The Tennessee value-added assessment system (TVAAS): Mixed-model methodology in educational assessment. Journal of Personnel Evaluation, 8, 299-311.

Shulman, L. S. (1986). Those who understand: Knowledge growth in teaching. Educational Researcher, 15(2), 4-14.

Torff, B., \& Sessions, D. N. (2005). Principals' perceptions of the causes of teacher ineffectiveness. Journal of Educational Psychology, 97(4), 530-537.

Torff, B., \& Sessions, D. N. (2009). Principals' perceptions of the causes of teacher ineffectiveness in different secondary subjects. Teacher Education Quarterly, 36(4), 127-148.

U.S. Department of Education (2004). Office of the Secretary, Office of Public Affairs. 


\section{PRINCIPALS' PERCEPTIONS}

A Guide to Education and No Child Left Behind. Washington, D.C. Retrieved from http:www2.ed.gov/print/nclb/overview/intor/guide/guide.html\#history. 


\section{PRINCIPALS' PERCEPTIONS}

SECTION SIX:

SCHOLARLY PRACTITIONER REFLECTION 
PRINCIPALS' PERCEPTIONS

\section{Scholarly Practitioner Reflection}

\section{Dissertation Influence on Practice as an Educational Leader}

Research into the perceptions of principals of the characteristics of highly

effective teachers has increased my awareness of the diversity of skill and ability of teachers in classrooms today. To listen to principals describe some of the most effective classroom teachers has helped me to refine and improve my own teaching practices.

Because my research focus was on the actual qualities necessary to be an effective teacher, it increased my awareness of the difficulties principals face as they try to ensure that all classrooms are staffed with a highly effective teacher. In the fall, I will be assuming the position of Instructional Coach for my high school. This job will require skill in identifying teachers who need assistance building pedagogical skill and pedagogical content knowledge in the classroom, as well as tact in working with those who are unaware that there are weaknesses in what they do. As we have seen from both my research and the literature used in this study, the content knowledge of the teachers should not be overlooked or minimized. Content knowledge should not be considered as less important than the pedagogical skill, or the pedagogical content knowledge needed to run a classroom.

I am more aware now that PCK and SCK are what gives an effective teacher the strength to be both creative in planning effective lessons and strong in building relationships and managing a learning environment. You take away subject content knowledge and the teacher's pedagogical skills will be undermined over time. Principals supported the idea that pedagogy was more difficult to learn quickly and a lack of skill in this area was more detrimental to the success of the teacher. In my new position as an 


\section{PRINCIPALS’ PERCEPTIONS}

instructional coach, I will definitely need to be aware of all three of the aspects of effective teaching and the needs of the teachers beyond basic classroom management challenges.

\section{Dissertation Process Influence on Scholarly Focus}

The dissertation process has been enlightening as to the amount of work it takes for scholars in the field of education to add worthwhile research information to the body of knowledge that already exists, which may be useful to others. It has caused me to gain a new respect for my profession and the research that has already been done which helps improve what I do in the classroom. The goal of all of the research in the field of education is to give all of our students an opportunity to have an excellent education. I realized, however, as I conducted my research how much disconnect occurs between the world of research and the realm of practice. So much research held in the world of academia does not seem to reach the educator in the classroom. During the research process, I learned a great deal about my profession that I was unaware of until this time.

I have enjoyed the entire dissertation process; however, I was excited to reach the point of gathering my own data and completing the research process. Looking at my profession from a scholarly view as well as through the eyes of the principal has helped me to reach a level of objectivity that I did not have before. Researching and writing may be something that I will want to pursue or continue to do in the future. 


\section{PRINCIPALS’ PERCEPTIONS}

\section{References}

A Nation at Risk Report: An Imperative for Educational Reform, April 1983. Retrieved from https://www2.ed.gov/pubs/NatAtRisk/risk.html

Allan, J., \& Catts, R. (2014). Schools, social capital and space. Cambridge Journal of Education, 44(2), 217-228. http://dx.doi.org/10.1080/0305764X.2013.863829

Austin, G. (1979). Exemplary schools and the search for effectiveness. Educational Leadership, October, 10-14.

Avolio, B. J., \& Gardner, W. L. (2005). Authentic leadership development: Getting to the root of positive forms of leadership. The Leadership Quarterly, 16, 315-338.

Bass, B. M. (1990). Bass and Stogdill's handbook of leadership: A survey of theory and research. New York: Free Press.

Bogdan, R. C., \& Biklen, S. K. (2007). Qualitative research for education: An introduction to theories and methods. Boston, MA: Pearson.

Bolman, L., \& Deal, T. (2008). Reframing organizations: Artistry, choice, and leadership. San Francisco, CA: Jossey-Bass.

Boyd, E., Lankford, H., Loeb, S., \& Wyckoff, J. (2005). The draw of home: How teachers' preferences for proximity disadvantage urban schools. Journal of Policy Analysis and Management, 24(1), 113-132.

Budge, K. (2006). Rural leaders, rural places: Problem, privilege, and possibility. Journal of Research in Rural Education, 21(13), 1-10.

Bryman, A. (1992). Charisma and leadership in organizations. London: Sage. Collins, J. (2011). Level 5 leadership: The triumph of humility and fierce resolve. In 


\section{PRINCIPALS’ PERCEPTIONS}

HBR's 10 Must reads on leadership (pp. 115-136), Boston, MA: Harvard Business Review Press. (Reprint R0507M, Originally published in January, 2001).

Cooper, B., Ehrensal, P., \& Bromme, M. (2005). School-level politics and professional development: Traps in evaluating the quality of practicing teachers. Educational Policy,19(1), 112-125. doi:10.1177/0895904804272231.

Darling-Hammond, L. (2000). Teacher quality and student achievement. Education Policy Analysis Archives, 8(1), 1-44. doi:http://dx.doi.org/10.14507/epaa.v8n1.2000.

Darling-Hammond, L. (2012). The right start: Creating a strong foundation for the teaching career. The Phi Delta Kappan, 94(3), 8-13.

Darling-Hammond, L., Amrein-Beardsley, A., Haertel, E., \& Rothstein, J. (2012). Evaluating teacher evaluation. The Phi Delta Kappan, 93(6), 8-15.

Darling-Hammond, L., Holtzman, D. J., Gatlin, S. J., \& Vazquez Heilig, J. (2005). Does teacher preparation matter? Evidence about teacher certification, teach for America, and teacher effectiveness. Education Policy Analysis Archives, 15, 151.

Darling-Hammond, L., Wise, A. E., \& Pease, S. R. (1983). Teacher evaluation in the organizational context: A review of the literature. Review of Educational Research, 53(3), 285-328. doi:10.3102/00346543053003285.

Darling-Hammond, L. \& Youngs, P. (2002). Defining "highly effective teachers": What does "scientifically-based research" actually tell us? Educational Researcher, 31(9), 13-25. 


\section{PRINCIPALS’ PERCEPTIONS}

Donaldson, M. (2013). Principals' approaches to cultivating teacher effectiveness: Constraints and opportunities in hiring, assigning, evaluating, and developing teachers. Educational Administration Quarterly, 49(5), 838-882. doi:10.1177/0013161X13485961.

Eagley, A. H. (2005). Achieving relational authenticity in leadership: Does gender matter? Leadership Quarterly, 16, 459-474.

ESEA - Elementary and Secondary Education Act (1965). Retrieved from http://ed.gov/esea.

ESSA - Every Student Succeeds Act: A progress report on elementary and secondary education, (2015). Retrieved from https://www.whitehouse.gov/sites/ whitehouse.gov/files/documents/ESSA_Progress_Report.pdf.

Finnigan, K., \& Gross, B. (2007). Do accountability policy sanctions influence teacher motivation? Lesson's from Chicago's low-performing schools. American Educational Research Journal, 44(3), 594-629.

Finnigan, K., \& Stewart, T. (2009). Leading change under pressure: An examination of principal leadership in low-performing schools. Journal of School Leadership, 19(5), 586-618.

Gamoran, A., \& Long, D. (2006). Equality of educational opportunity: A 40-year retrospective. WCER Working Paper, 2006-9 (Madison, WI, Wisconsin Center for Education Research).

Gates Foundation (2013). Measures of effective teaching. Retrieved from http://www.gatesfoundation.org/Media-Center/Press-Releases/2013/01/Measures of-Effective-Teaching-Project-Releases-Final-Research-Report. 


\section{PRINCIPALS’ PERCEPTIONS}

Gitlin, A., \& Smyth, J. (1989). Teacher evaluation: Educative alternatives. Philadelphia, PA: Falmer Press, Taylor \& Francis, Inc.

Grossman, P. (1990). The making of a teacher: Teacher knowledge and teacher education. New York, NY: Teachers College Press.

Hallinger, P., Heck, R., \& Murphy, J. (2014). Teacher evaluation and school improvement: An analysis of the evidence. Educational Assessment, Evaluation and Accountability, 26, 5-28. doi:10.1007/s11092-013-9179-5.

Hammond, J., Keeney, R., \& Raiffa, H. (2013). The hidden traps in decision making. In HBR's 10 must reads on making smart decision (pp. 1-19), Boston, MA: Harvard Business Review Press. (Reprint R0601K, Originally published in January, 2006).

Hattie, J. A. (2003, October). Teachers make a difference: What is the research evidence? Paper presented at the Building Teacher Quality: What does the research tell us? ACER Research Conference, Melbourne, Australia. Retrieved from http://research.acer.edu.au/research_conference_2003/4/

Hattie, J. A. (2009). Visible learning: A synthesis of over 800 meta-analyses relating to achievement. New York, NY: Routledge.

Holland, H. (2007). Can educators close the achievement gap? An interview with Richard Rothstein and Kati Haycock. National Staff Development Council, 28(1), 54-62.

Ingle, W. K., \& Rutledge, S. A. (2010). Selecting the "best applicant(s)" with limited options and policy constraints. Journal of Cases in Educational Leadership, 13(1), 37-47. doi:10.1177/1555458910369786. 


\section{PRINCIPALS’ PERCEPTIONS}

Ingle, K., Rutledge, S., \& Bishop, J., (2011). Context matters: Principals’ sensemaking of teacher hiring and on-the-job performance. Journal of Educational Administration, 49(5), 579-610. doi:10.1108/09578231111159557.

Jackson, C. K., \& Bruegmann, E. (2009). Teaching Students and Teaching Each Other: the importance of peer learning for teachers. NBER Working Paper, 15202 (Cambridge, MA, National Bureau of Economic Research).

Jencks, C., \& Phillips, M. (1998). The black-white test score gap. Washington, DC: Brookings Institution Press.

Johnson, L. (1999). The learning gap: Highlighting teachers' competency. Nieman Reports, Spring, 40-42.

Jung, D., \& Sosik, J. J. (2006). Who are the spellbinders? Identifying personal attributes of charismatic leaders. Journal of Leadership \& Organizational Studies, 12, 12 27.

Kotter, J. P. (2011). What leaders really do. In HBR's 10 must reads on leadership (pp. 37-55), Boston, MA: Harvard Business Review Press. (Reprint R0111F, Originally published in May, 1990).

Leithwood, K. (2010). Characteristics of school districts that are exceptionally effective in closing the achievement gap. Leadership and Policy in Schools, 9, 245-291. doi:10.1080/15700761003731500.

Leroy, H., Palanski, M., \& Simons, T. (2012). Authentic leadership and behavioral integrity as drivers of follower commitment and performance. Journal of Business Ethics, 107, 255-264. doi:10.1007/s1055-011-1036-1.

Levi, D. (2014). Group dynamics for teams. Los Angeles, CA: SAGE Publications, Inc. 


\section{PRINCIPALS’ PERCEPTIONS}

Lewis, A. (1982). Evaluating educational personnel. Arlington, VA: American Association of School Principals.

Loeb, S., Kalogrides, D., \& Beteille, T. (2012). Effective schools: Teacher hiring, assignment, development and retention. Education Finance and Policy, 7(3), 269-304.

Looney, J. (2011). Developing high-quality teachers: Teacher evaluation for improvement. European Journal of Education, 46(4), 440-455.

Marsh, F. (2010). High performance team: Building a business program with part- and full-time faculty. Journal of Education for Business, 85, 187-194. doi:10.1080/08832320903252421.

McGough, D. (2003). Leaders as learners: An inquiry into the formation and transformation of principals' professional perspectives. Educational Evaluation and Policy Analysis, 25(4), 449-471.

McLaughlin, M. W., \& Pfeifer, R. S. (1988). Teacher evaluation: Improvement, accountability, and effective learning. New York, NY: Teachers College Press.

Merriam, S. (2009). Qualitative research: A guide to design and implementation. San Francisco, CA: Jossey-Bass.

Meyer, R. (1997). Value added indicators of school performance: A primer. Economics of Education Review, 16(3), 283-301.

Millman, J., \& Darling-Hammond, L. (1990). The new handbook of teacher evaluation: Assessing elementary and secondary school teachers. Thousand Oaks, CA: Corwin Press; a SAGE Publications Company.

Mintzberg, H. (2005). The five basic parts of the organization. In Classics of 


\section{PRINCIPALS' PERCEPTIONS}

organizational theory, (pp. 219-230), Belmont, CA: Thomson Wadsworth. (Reprinted by permission of Harvard Business Review, Originally published January-February, 1990)

Missouri Department of Elementary and Secondary Education (2016). Retrieved from http://mcds.dese.mo.gov/quickfacts/SitePages/DistrictInfo.aspx

Missouri Department of Elementary and Secondary Education (2016). Administrator Certification. Retrieved from https://dese.mo.gov/educatorquality/certification/administrator.

Mumford, M. D., Zaccaro, S. J., Harding, F. D., Jacobs, T. O., \& Fleishman, E. A. (2000). Leadership skills for a changing world: Solving complex social problems. Leadership Quarterly, 11(1), 11-35.

National Center for Education Statistics (2006). Rural Education in America. National Center for Education Statistics, Institute of Education Sciences, U.S. Department of Education, Washington, D.C. Retrieved from https://nces.ed.gov/surveys/ruraled/definitions.asp.

National Center for Education Statistics (2013). The Nation's Report Card: Trends in Academic Progress 2012 (NCES 2013-456). National Center for Education Statistics, Institute of Education Sciences, U.S. Department of Education, Washington, D.C. Retrieved from http://nces.ed.gov/nationsreportcard/subject/publications/main2012/pdf.

Nixon, A., Packard, A., \& Dam, M. (2016). Teacher contract non-renewal: What matters to principals? International Journal of Educational Leadership Preparation, 11(1). 


\section{PRINCIPALS’ PERCEPTIONS}

No Child Left Behind Act of 2001. Public Law Number 107-110 (2001). Retrieved from www2.ed.gov/nclb/landing.jhtml.

Noguera, P. (2007). Closing the racial achievement gap: The best strategies of the schools we send them to. In Motion Magazine, published online. Retrieved from http://www.inmotionmagazine.com/er/pn_strat.html.

Northouse, P. (2013). Leadership: Theory and practice. Thousand Oaks, CA: SAGE Publications, Inc.

Putnam, R. (1995). Tuning In, Tuning Out: The Strange Disappearance of Social Capital in America. Political Science and Politics, 28(4), 664-683.

Reininger, M. (2012). Hometown disadvantage? It depends on where you're from: Teachers' location preferences and the implications for staffing schools. Educational Evaluation and Policy Analysis, 34(2), 127-145.

Rivkin, S., Hanushek, E., \& Kain, J. (2005). Teachers, schools, and academic achievement. Econometrica, 73(2), 417-458.

Rojas-LeBouef, A., \& Slate, J. R. (2011). The achievement gap between white and nonwhite students: A conceptual analysis. International Journal of Educational Leadership Preparation, 6(4). Retrieved from http://cnx.org/content/m41405/1.1/

Sanders, W., \& Horn, S. (1994). The Tennessee value-added assessment system (TVAAS): Mixed-model methodology in educational assessment. Journal of Personnel Evaluation, 8, 299-311.

Shamir, B., \& Eilam, G. (2005). "What's your story?” A life-stories approach to authentic leadership development. Leadership Quarterly, 16, 395-417.

Shulman, L. S. (1986). Those who understand: Knowledge growth in teaching. 


\section{PRINCIPALS' PERCEPTIONS}

Educational Researcher, 15(2), 4-14.

Shulman, L. S. (1987). Knowledge and teaching: Foundations of the new reform. Harvard Educational Review, 57(1), 1-22.

Stronge, J. H., Richard, H. B., \& Catano, N. (2008). Qualities of Effective Principals. Alexandria, VA: Association for Supervision and Curriculum Development.

Taylor, E. W. (2009). Fostering transformative learning. In J. Mezirow \& E. W. Taylor (Eds.), Transformative learning in practice: Insights from community, workplace, and higher education (pp. 3-17). San Francisco, CA: Jossey-Bass

Torff, B., \& Sessions, D. N. (2005). Principals' perceptions of the causes of teacher ineffectiveness. Journal of Educational Psychology, 97(4), 530-537.

Torff, B., \& Sessions, D. N. (2009). Principals' perceptions of the causes of teacher ineffectiveness in different secondary subjects. Teacher Education Quarterly, 36(4), 127-148.

U.S. Department of Education (2004). Office of the Secretary, Office of Public Affairs. A Guide to Education and No Child Left Behind. Washington, D.C. Retrieved from http:www2.ed.gov/print/nclb/overview/intor/guide/guide.html\#history.

Wright, S. P., Horn, S. P., \& Sanders, W. L. (1997). Teacher and classroom context effects on student achievement: Implications for teacher evaluation. Journal of Personnel Evaluation in Education, 11, 57-67. 


\title{
APPENDIX A
}

Letter of Introduction and Informed Consent Form

\section{Project/Study Title: Rural Missouri Principals' Perceptions of Highly Effective Teachers: Does it Align with National Research?}

\author{
Researcher: Marcia Sankey
}

Before agreeing to participate in this research, we strongly encourage you to read the following explanation of this study. This statement describes the purpose and procedures of the study. Also described is your right to withdraw from the study at any time.

\section{Explanation of Procedures}

This study is designed to examine the perceptions of high school principals of the characteristics of a highly effective teacher throughout the evaluation and hiring process. We are conducting this study to learn more about this question since it has not been studied much in the past. Participation in the study involves a face-to-face interview, which will last for approximately one to two hours. The interviews will be conducted by the researcher, audiotaped and later transcribed for the purpose of data analysis. Interviews will be conducted at the principal's high school, district office or another location nearby.

Risks and Discomforts

There are no risks or discomforts that are anticipated from your participation in the study.

\section{Benefits}

The anticipated benefit of participation is the opportunity to discuss feelings, perceptions, and concerns related to the experience of evaluating and hiring highly effective high school teachers and to contribute to understanding of the impact of principal perceptions on this process.

\section{Confidentiality}

The information gathered during this study will remain confidential in secure premises during this project. Only the researcher will have access to the study data and information. There will not be any identifying names on the interview transcripts; they will be coded and the key to the code will be kept locked away. Your names and any other identifying details will never be revealed in any publication of the results of this study. The results of the research will be published in the form of a research paper and may be published in a professional journal or presented at professional meetings. It may also be published in book form. The knowledge obtained from this study will be of great value in guiding professionals to be more effective in understanding and perceiving the characteristics of a highly effective high school teacher.

\section{Withdrawal without Prejudice}




\section{PRINCIPALS’ PERCEPTIONS}

Participation in this study is voluntary; refusal to participate will involve no penalty. You are free to withdraw consent and discontinue participation in this project at any time without prejudice or penalty. You are also free to refuse to answer any question the researcher may ask.

Further Questions and Follow-Up

You are welcome to ask the researchers any questions that occur to you during the interview. If you have further questions once the interview is completed, you are encouraged to contact the researchers using the contact information given below.

If, as a result of participating in this study, you feel the need for further, longer-term support, you are welcome to contact Marcia Sankey at mfs7d4@mail.missouri.edu as well as Dr. Juanita Simmons at simmonsjm@missouri.edu

You may contact the Campus Institutional Review Board if you have questions about your rights, concerns, complaints or comments as a research participant. You can contact the Campus Institutional Review Board directly by telephone or email to voice or solicit any concerns, questions, input or complaints about the research study.

Campus Institutional Review Board E-Mail: umcresearchcirb@missouri.edu Website: http://www.research.missouri.edu/cirb/index.htm

483 McReynolds Hall

Columbia, Mo 65211

573-882-9585 
PRINCIPALS' PERCEPTIONS

Interview Questions

\section{APPENDIX B}

Background/Warm-up Questions:

1. How long have you been in education?

2. What did you teach when you first got into education and what did you enjoy most?

What did you enjoy the least?

3. What do you feel were your strengths and weaknesses as a classroom teacher?

Questions for Data Collection:

1. How long have you been a principal? How long in this district/at this school?

2. What is the most rewarding part of being a principal?

3. What is the most challenging part?

4. Describe the general process for evaluating teachers in this district/building.

5. How many teachers are you responsible for evaluating each school year?

6. How much time each day to you get to spend in the classrooms?

7. What characteristics come to mind when you think about what a highly effective teacher does in the classroom?

8. What do they do outside of class time, before school, during passing time, after school?

9. What do you feel is the most important characteristic of a highly effective teacher? Least important?

10. When you conduct teacher evaluations, what things are you looking for in the classroom, which indicate to you a teacher is highly effective?

11. Tell me about a time when you saw a highly effective teacher in action.

12. Are you a part of the interview and hiring process? If so, what characteristics do you look for in a teacher candidate/applicant to help identify a highly effective teacher? 


\section{PRINCIPALS’ PERCEPTIONS}

VITA

Marcia Sankey earned a Bachelor of Science in Education with an emphasis in secondary Social Studies from the University of Missouri - Columbia and later completed a Masters in Curriculum and Instruction at William Woods University in Fulton, Missouri.

Marcia has worked in a variety of different settings, including both public and private schools, as well as several years with the Missouri Division of Youth Services as a youth specialist. Marcia has worked at Jefferson City High School for the last twentyone years as a high school social studies teacher. She has also held the position of Social Studies department chair/lead teacher twice in that time. In July of 2017, Marcia began a new position as the A+Coordinator and Instructional Coach at Jefferson City High School. 